\title{
19. GEOCHEMISTRY AND PETROGENESIS OF JURASSIC OCEAN CRUST BASALTS, SITE $801^{1}$
}

\author{
P. A. Floyd ${ }^{2}$ and P. R. Castillo ${ }^{3}$
}

\begin{abstract}
Middle Jurassic basaltic lavas obtained from Site 801 in the western Pacific Pigafetta Basin represent ocean crust from the oldest segment of the present-day Pacific Ocean. A composite $131 \mathrm{~m}$ section shows the basement to be composed of an upper alkalic basalt sequence (about $157 \mathrm{Ma}$ ) with ocean island basalt chemical features and a lower tholeitic basalt sequence (about $167 \mathrm{Ma}$ ) with typical normal-type mid-ocean ridge basalt features. The basalt sequences are separated by a quartz-cemented, yellow goethite hydrothermal deposit. Most basalts are altered to some degree and exhibit variable, low-grade smectiteceladonite-pyrite-carbonate-zeolite assemblages developed under a mainly hydrated anoxic environment. Oxidation is very minor, later in development than the hydration assemblages, and largely associated with the hydrothermal deposit. The tholeiitic normal-type mid-ocean ridge basalt has characteristically depleted incompatible element patterns and all compositions, are encompassed by recent mid-ocean ridge basalt from the East Pacific Rise. Chemically, the normal-type mid-ocean ridge basalt is divided into a primitive plagioclase-olivine \pm spinel phyric group $\left(\mathrm{Mg}^{*}=72-60\right)$ and an evolved (largely) aphyric group of olivine tholeiites $\left(\mathrm{Mg}^{*}=62-40\right)$. Both groups form a single comagmatic suite related via open-system fractionation of initial olivine-spinel followed by olivine-plagioclase-clinopyroxene. The alkalic ocean island basalt are largely aphyric and display enriched incompatible element abundances within both relatively primitive olivine-rich basalts and evolved olivine-poor hawaiites related via mafic fractionation. In gross terms, the basement lithostratigraphy is a typical mid-ocean ridge basalt crust, generated at a spreading center, overlain by an off-axis seamount with ocean island basalt chemical characters.
\end{abstract}

\section{INTRODUCTION}

On the basis of Mesozoic magnetic anomaly correlations the oldest (and largest) segment of present-day ocean crust of Jurassic age occurs in the western Pacific Ocean between anomaly M17 and the Bonin-Mariana volcanic arcs (Larson and Chase, 1972). One of the main objectives of Ocean Drilling Program (ODP) Leg 129 was to drill a complete Jurassic sequence of deep-sea sediments and penetrate the oldest in-situ basaltic ocean crust in this region of the western Pacific Ocean. Underlying a sequence of red radiolarite and claystone of Callovian-Bathonian age (Matsuoka, 1990) basaltic basement was successfully penetrated at Site 801 in the southern Pigafetta Basin (Fig. 1). Basement is essentially composed of an upper alkalic basalt sequence and a lower tholeiitic basalt sequence separated by a hydrothermal deposit. The Middle Jurassic age of this basement is confirmed by ${ }^{40} \mathrm{Ar}{ }^{\beta 9} \mathrm{Ar}$ dates from both the upper (about $157 \mathrm{Ma}$ ) and lower (about $167 \mathrm{Ma}$ ) sequences (Pringle, this volume). In this paper we present a more detailed account of the petrographic and geochemical data from the Jurassic basement basalts from Site 801 than previously outlined (Floyd et al., 1991). Companion papers on the basalts in this volume detail the isotopic geochemistry (Castillo et al.), alteration (Alt et al.), and phase chemistry (Floyd and Rowbotham).

\section{ANALYTICAL METHODS}

Samples selected aboard ship were between 25 and $35 \mathrm{~cm}^{3}$ in volume and after removal of a slice for the preparation of a thin section, were totally crushed to $<120$ mesh in an agate Tema mill. Different aliquots of powder were used for X-ray fluorescence (XRF) analysis, instrumental neutron activation analysis (INAA), induc-

' Larson, R. L., Lancelot, Y., et al., 1992.Proc. ODP, Sci. Results, 129: College Station, TX (Ocean Drilling Program).

${ }^{2}$ Department of Geology, University of Keele, Staffordshire, ST5 5BG, United Kingdom.

${ }^{3}$ Scripps Institute of Oceanography, La Jolla, CA 92093-0220, U.S.A. tively coupled plasma (ICP) source spectrometry, and separate determinations of $\mathrm{FeO}$, loss on ignition (LOI), $\mathrm{H}_{2} \mathrm{O}^{+}$and $\mathrm{CO}_{2}$.

Major oxides and many trace elements (see the following) were analyzed by standard XRF techniques (Norrish and Hutton, 1969; Leake et al., 1969) using an ARL 8420 Quantometer (Geoscience Analytical Services, University of Keele; analysts: M. Aikin and D. Emley) calibrated with $20-40$ international and inhouse rock standards of appropriate composition. Major oxides were determined in a fused glass bead (1:5 mixture of ignited sample and lithium metaborate flux) and trace elements ( $\mathrm{Ba}, \mathrm{Ce}, \mathrm{Cl}, \mathrm{Cr}, \mathrm{Cu}, \mathrm{Ga}, \mathrm{La}, \mathrm{Nb}, \mathrm{Nd}, \mathrm{Ni}, \mathrm{Pb}, \mathrm{Rb}, \mathrm{S}, \mathrm{Sr}, \mathrm{V}, \mathrm{Y}, \mathrm{Zn}$, and $\mathrm{Zr}$ ) in a pressed powder pellet. On the basis of replicate analysis of International standards the error (measured by the coefficient of variation) for major oxides is generally $1.0 \%-1.5 \%$ (except $0.5 \%$ for $\mathrm{SiO}_{2}$ and total $\mathrm{Fe}$ as $\mathrm{Fe}_{2} \mathrm{O}_{3}$ ) and $<5 \%$ for most trace elements (but about $10 \%$ for $\mathrm{La}, \mathrm{Ce}$ and $\mathrm{Nd}$ ). $\mathrm{FeO}$ was determined by titration with potassium dichromate. $\mathrm{H}_{2} \mathrm{O}$ and $\mathrm{CO}_{2}$ were analyzed together with an $\mathrm{HNC}$ Analyser at Centre de Recherches Petrographiques et Geochimiques, Vandoeuvre (analyst: C. France-Lanord), with the total correlating well ( $r=0.99)$ with LOI determined at the University of Keele.

Rare earth elements (REE) and other trace elements (including Co, $\mathrm{Cs}, \mathrm{Hf}, \mathrm{Sc}, \mathrm{Ta}, \mathrm{Th}$, and U) were analyzed in a subset of the Site 801 samples by INAA at the Universities Research Reactor, Risley, United Kingdom (analyst: G. Gilmore) and the Department of Earth and Planetary Science, Washington University, U.S.A. (analyst: R. Korotev). REE were also determined by ICP at Royal Holloway and Bedford New College, University of London, United Kingdom (analyst: N. Walsh). To check interlaboratory correlation and different analytical techniques, four samples were selected for replicate analysis by the various laboratories. The results (Table 1) show a good measure of correspondence between REE determined by ICP and INAA, and other trace elements determined by XRF and INAA. For a full record of analytical data on the basement basalts (including isotopes) see the Data Report by Castillo et al. (this volume).

Normative calculations were performed on chemical data recalculated to an LOI-free basis and a standard oxidation ratio of 0.15 (Brooks, 1976) to reduce the effects of secondary oxidation on the standard CIPW norm. 


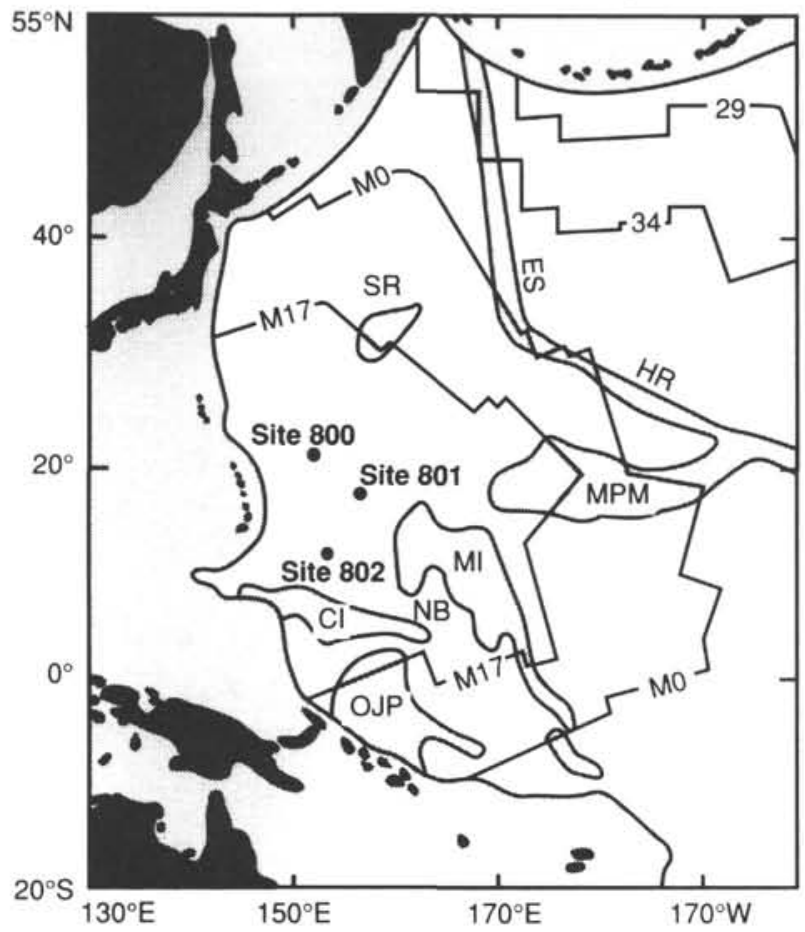

Figure 1. Map of the western Pacific Ocean showing the position of ODP Leg 129 Sites 800,801, and 802 (Lancelot, Larson, et al., 1990). Open area represents normal Pacific Ocean crust with magnetic lineation contours, whereas shaded areas represent thickened crustal sections and younger crust to the west of the Pacific subduction zones. Feature abbreviations are as follows: Caroline Islands (CI), Ontong-Java Plateau (OJP), Marshall Islands (MI), Nauru Basin (NB), Mid-Pacific Mountains (MPM), Shatsky Rise (SR), Hawaiian Ridge (HR), and Emperor Seamounts (ES).

\section{VOLCANIC COOLING UNITS}

At Site 801 , Holes $801 \mathrm{~B}$ and $801 \mathrm{C}$ penetrated basaltic basement to about 50 and $100 \mathrm{~m}$ below seafloor (mbsf), respectively, and recovered a series of mainly thin flows and pillow lavas together with a discordant dike-like intrusive and a single thick (about $13.5 \mathrm{~m}$ ) flow (Lancelot, Larson, et al., 1990). The identification of individual cooling units and the position of boundaries (some inferred owing to lack of recovery) were based on both textural (chilled/glassy margins; systematic grain-size variation) and mineralogical (present or absence of phenocrysts and specific phenocryst assemblages) criteria, together with the presence of sparse sediment interlayers. In Hole 801B, 14 magmatic cooling units (hereafter referred to as B1-B14) were recognized, and another 30 (C1-C32; two units are sedimentary) in Hole $801 \mathrm{C}$. Apart from the pillow lavas with clearly recognizable curved glassy margins, cooling units that exhibited both upper and lower chilled boundaries are generally $1-4 \mathrm{~m}$ in thickness and as in other ocean basalt studies (e.g., Adamson, 1985), were considered to represent thin flows. No packets of very thin sheet flows with numerous horizontal glassy selvages were recognized.

Textural variation within the thin flows and the presence of pillow lavas are clear evidence for the submarine extrusion of a series of basaltic lava flows. At Site 801 the sequence of textures from flow margin to interior is characteristic of many flows described from oceanic basement (e.g., Bryan, 1972; Natland, 1980; Goldfarb, 1986) and is related to the cooling history of the lava, together with nucleation and growth processes of individual crystals. The following is a generalized account of the typical textural features displayed from glassy rim to crystalline interior of Site 801 flows. The preservation of glassy margins is generally rare (commonly destroyed by drilling), and where observed the margins are invariably replaced by either yellowish palagonite or, more usually, dark brown smectite. In porphyritic units quenched plagioclase microlites with forked and splayed terminations are common and may act as nucleation sites for dark brown spherulites. Initially the spherulites are not completely spherical, but may exhibit a four or sixfold cross of curved plumose crystallites set in an altered glassy matrix. As the spherulites grow in size they coalesce such that the proportion of glassy matrix rapidly decreases inward. Toward the flow interior a hypocrystalline variolitic zone is common with both fan and sheaf variolites commonly composed of skeletal clinopyroxene or some plagioclase. These structures gradually become coarser and in the case of plagioclase may be constructed of open radiate groups of elongate ( $2 \mathrm{~mm}$ long) serrated crystals nucleated on a central point. Around the margins of some clinopyroxene fan variolites, granules of titanomagnetite may be concentrated. Flow interiors are commonly holocrystalline although glassy (altered) mesostasis crowded with curved plagioclase microlites and titanomagnetite granules occur in all but the thickest flows. The grain-size may be medium-grained, although both plagioclase and clinopyroxene may still exhibit morphologies indicative of fairly rapid growth. For example, clinopyroxene forms stubby to elongate subhedral individual prims as well as coaxial radiate growths with serrated plagioclase. However, most plagioclase by now exhibits lath-shaped forms. With the exception of the thickest flows, typical subophitic relationships are generally rare and dissimilar to that generally found in thick coarse-grained sills. In Site 801 microdolerites, this texture is represented by localized growth centers composed of a large central anhedral clinopyroxene grain from which wedge-shaped plagioclase laths radiate into the matrix.

\section{LITHOSTRATIGRAPHY AND INTERHOLE CORRELATION}

Hole $801 \mathrm{~B}$ is characterized by hypocrystalline and holocrystalline aphyric alkalic basalts, which in the thicker flows grade into microdolerites and dolerites in their interiors. Units B6 and B7, however, are characterized by a relatively coarser grain size and form a distinctive group of olivine-rich alkalic dolerites. At the base of the hole is a thin, plagioclase microphyric glassy apophysis or dike (unit B14) intrusive into the aphyric basalt cooling unit above (unit B13). Hole $801 \mathrm{C}$ was drilled about $20 \mathrm{~m}$ to the north and recovered another basement sequence. The upper section is similar to that in Hole 801B and is likewise composed of aphyric alkalic basalts and microdolerites. However, at about 522-531 mbsf is a yellow ochrous hydrothermal deposit, below which is a predominantly aphyric sequence of tholeiitic basalts that constitute the rest of the lower section of Hole 801C. Interspersed with the aphyric flows are sparsely to moderately phyric flows, and apart from a concentration directly below the hydrothermal deposit (units C9-C20), show no systematic distribution. The total lithologic variation displayed by the two holes is shown diagrammatically in Figure 2 (for further details of individual units see Lancelot, Larson, et al., 1990). Note that the hydrothermal deposit (unit $\mathrm{C} 8$ ) provides a convenient marker that divides the Jurassic basement into an upper alkalic basalt sequence and a lower tholeiitic basalt sequence.

Because of the proximity of the two holes and the presence of distinctive features in the alkalic basalts, the lithology can be correlated and combined into a single sequence representative of Jurassic basement at Site 801 . The following criteria were used for interhole correlation: (1) the presence of the intrusive dike-like glassy apophysis (correlating units B14 with C4 + C6; see Fig. 39 in Lancelot, Larson, et al. 1990), (2) lithologic comparison between the olivinerich alkalic dolerites (correlating units B6 + B7 and $\mathrm{C} 1$ ), and (3) chemical discrimination that shows units $\mathrm{B} 6+\mathrm{B} 7$ and $\mathrm{C} 1$ have a similar composition that is clearly different to the adjacent units. This is illustrated in Figure 3 where the high $\mathrm{Ni}$ abundance reflects the particularly olivine-rich nature of these alkalic basalts, which are also characterized by higher than usual $\mathrm{Cr}$ and $\mathrm{MgO} / \mathrm{FeO}^{*}$ ratios. 
Table 1. Comparison of interlaboratory results for the duplicate analysis of selected Leg 129 basalts.

\begin{tabular}{|c|c|c|c|c|c|c|c|c|}
\hline \multirow{2}{*}{$\begin{array}{l}\text { Hole: } \\
\text { Core, section: } \\
\text { Interval }(\mathrm{cm}) \text { : } \\
\text { Analytical laboratory: }\end{array}$} & \multicolumn{2}{|c|}{$\begin{array}{c}802 \mathrm{~A} \\
59 \mathrm{R}-1 \\
7-12\end{array}$} & \multicolumn{2}{|c|}{$\begin{array}{l}802 A \\
61 R-1 \\
32-37\end{array}$} & \multicolumn{2}{|c|}{$\begin{array}{c}801 \mathrm{C} \\
2 \mathrm{R}-1 \\
112-118\end{array}$} & \multicolumn{2}{|c|}{$\begin{array}{c}801 \mathrm{C} \\
10 \mathrm{R}-6 \\
67-70\end{array}$} \\
\hline & Keele & Wash & Keele & Wash & Keele & Wash & Keele & Wash \\
\hline \multicolumn{9}{|l|}{ Major oxides (wt\%) } \\
\hline $\mathrm{FeO}^{*}$ & 10.87 & 11.11 & 11.04 & 11.31 & 9.15 & 8.79 & 9.70 & 10.04 \\
\hline $\mathrm{CaO}$ & 11.97 & 11.80 & 11.72 & 11.70 & 7.14 & 6.70 & 12.26 & 11.50 \\
\hline $\mathrm{Na}_{2} \mathrm{O}$ & 2.08 & 2.06 & 2.08 & 2.07 & 3.94 & 3.53 & 2.77 & 2.74 \\
\hline \multicolumn{9}{|l|}{ Trace elements (ppm) } \\
\hline $\mathrm{Ba}$ & 7 & $<22$ & 20 & $<70$ & 396 & 341 & 9 & $<80$ \\
\hline $\mathrm{Cr}$ & 139 & 153 & 160 & 155 & 87 & 92.1 & 200 & 198 \\
\hline Cs & 0.10 & 0.11 & 0.16 & 0.24 & 0.44 & 0.39 & 0.10 & $<0.30$ \\
\hline $\mathrm{Hf}$ & 1.50 & 1.75 & 1.70 & 1.74 & 5.7 & 5.9 & 2.60 & 2.63 \\
\hline $\mathrm{Ni}$ & 103 & 107 & 95 & $<153$ & 42 & 43 & 67 & 70 \\
\hline $\mathrm{Rb}$ & 1 & $<10$ & 6 & $<13$ & 44 & 43 & 1 & $<9$ \\
\hline Sc & 47.6 & 50.2 & 48.7 & 50.1 & 21.5 & 20.4 & 45.9 & 48.4 \\
\hline $\mathrm{Sr}$ & 100 & 104 & 100 & 100 & 477 & 500 & 118 & 80 \\
\hline $\mathrm{Ta}$ & 0.17 & 0.194 & 0.18 & 0.18 & 2.46 & 2.63 & 0.124 & 0.123 \\
\hline $\mathrm{Th}$ & 0.24 & 0.27 & 0.28 & 0.18 & 2.43 & 2.43 & 0.109 & $<0.15$ \\
\hline $\mathrm{U}$ & 0.112 & $<0.3$ & 0.097 & $<0.4$ & 0.81 & 0.96 & 0.10 & $<0.7$ \\
\hline $\mathrm{Zr}$ & 66 & 60 & 66 & $<155$ & 259 & 230 & 101 & 120 \\
\hline \multicolumn{9}{|l|}{ Rare earth elements (ppm) } \\
\hline $\mathrm{La}$ & 3.96 & 3.23 & 3.77 & 3.41 & 31.16 & 27.50 & 3.26 & 2.80 \\
\hline $\mathrm{Ce}$ & 10.28 & 8.70 & 9.53 & 8.90 & 64.62 & 58.60 & 10.08 & 9.20 \\
\hline $\mathrm{Nd}$ & 8.30 & 7.20 & 7.76 & $<21$ & 31.68 & 30.00 & 10.38 & 6.00 \\
\hline $\mathrm{Sm}$ & 2.35 & 2.41 & 2.30 & 2.42 & 6.93 & 6.93 & 3.33 & 3.47 \\
\hline $\mathrm{Eu}$ & 0.91 & 0.91 & 0.92 & 0.92 & 2.32 & 2.30 & 1.30 & 1.32 \\
\hline $\mathrm{Yb}$ & 2.57 & 2.51 & 2.44 & 2.41 & 2.58 & 2.47 & 3.68 & 3.62 \\
\hline $\mathrm{Lu}$ & 0.43 & 0.378 & 0.41 & 0.386 & 0.42 & 0.345 & 0.62 & 0.53 \\
\hline
\end{tabular}

${ }^{a}$ Analyses performed at the University of Keele (Keele) and University of Washington (Wash).

Further description and discussion in this paper will now refer to a single Site 801 basement stratigraphy amalgamated from Holes $801 \mathrm{~B}$ and $801 \mathrm{C}$. Correlation between lithology, cooling units, and chemical groups (to be described in the following) at Site 801 is summarized in Table 2 .

\section{PETROGRAPHY}

Excluding sediment interlayers, Site 801 basement is composed of an upper sequence of alkalic basalts (about $52 \mathrm{~m}$ thick) and a lower sequence of tholeiitic basalts (about $64 \mathrm{~m}$ thick), of which about $75 \%$ is aphyric (based on recovered core only). Apart from the sporadic plagioclase or olivine phenocryst within these basalts, a number of sparsely to moderately phyric basalts display the following phenocryst assemblages: spinel-olivine; plagioclase-olivine, and olivineplagioclase-clinopyroxene. In the following we outline the primary petrographic features of both aphyric and phyric basalt types, some of which are also illustrated in Plate 1. The associated phase chemistry is documented by Rowbotham and Floyd (this volume).

\section{Alkalic Basalts and Dolerites}

Textures of aphyric basalts grade from glassy variolitic margins to holocrystalline intersertal and subophitic flow interiors. The coarser flow segments are typified by abundant strongly pleochroic pink titaniferous clinopyroxene and albite-twinned plagioclase laths that may also be zoned. Olivine is generally present as a minor constituent (invariably replaced by various secondary phases), although abundant (up to 15\%) in the olivine-rich dolerites (units B6, B7, and $\mathrm{Cl}$ ) where it occurs as small, equant lantern-shaped prisms. Titanomagnetite occurs as either granules or elongate skeletal needles (1.0-1.5 mm in length). Long clear needles of apatite are a characteristic accessory phase and appear to have developed late in the crystallization sequence. Another phase common to all the alkalic basalts is a dark brown, strongly pleochroic, biotite that forms masses of anhedral to subhedral plates. The biotite may commonly nucleate on titanomagnetite granules and is late-magmatic in origin. In addition, the olivine-rich dolerites show the preservation of rare, dark brown pleochroic amphibole, which together with biotite, indicates that the magmas became hydrated as crystallization proceeded.

The main phenocryst assemblage exhibited by the alkalic rocks is plagioclase with variable olivine. Plagioclase phenocrysts (1-3 mm long) may be Carlsbad and/or albite twinned with faint oscillatory zoning (cores with $\mathrm{An}_{75-55}$ ). Small, equant ( $1 \mathrm{~mm}$ ) olivine phenocrysts (always replaced by secondary minerals) are recognized from their characteristic form and commonly feature hopper-shaped faces. The matrix mineralogy is similar to that of the aphyric units, including the presence of biotite, rare brown amphibole, and abundant apatite.

The interiors of both aphyric and phyric alkali basalt and dolerite flows may exhibit the remnants of a quenched glassy mesostasis. The glass is generally replaced by a brownish or greenish smectite, within which are embedded curved or straight, serrated plagioclase microlites and titanomagnetite granules. Small magmatic biotite plates may also be associated with the mesostasis and reinforce its late development in the crystallization history of these rocks.

\section{Tholeiitic Basalts}

Although aphyric tholeiites make up the majority of the flows (about $66 \%$ ) below the hydrothermal deposit, many contain a few microphenocrysts of olivine, plagioclase, and/or clinopyroxene. In general terms, these sparse crystals are distributed such that the olivine phenocrysts found in the uppermost flows (which also contain matrix olivine) give way to clinopyroxene in the lower flows (with no or very little matrix olivine). An additional feature is that nearly all the aphyric flows are poorly vesicular, although the distribution of the circular vesicles $(0.2-$ $0.5 \mathrm{~mm}$ in diameter) is highly irregular both within and between cooling units. The aphyric flows are commonly hypocrystalline and quench-textured throughout, with characteristic cooling textures from flow margins to flow interiors. Unit C25 is the thickest cooling unit (about $13.5 \mathrm{~m}$ ) and will be used to illustrate the textural and mineralogical variation within 
Table 2. Correlation of lithology, cooling units, and chemical groups relative to depth, Site 801.

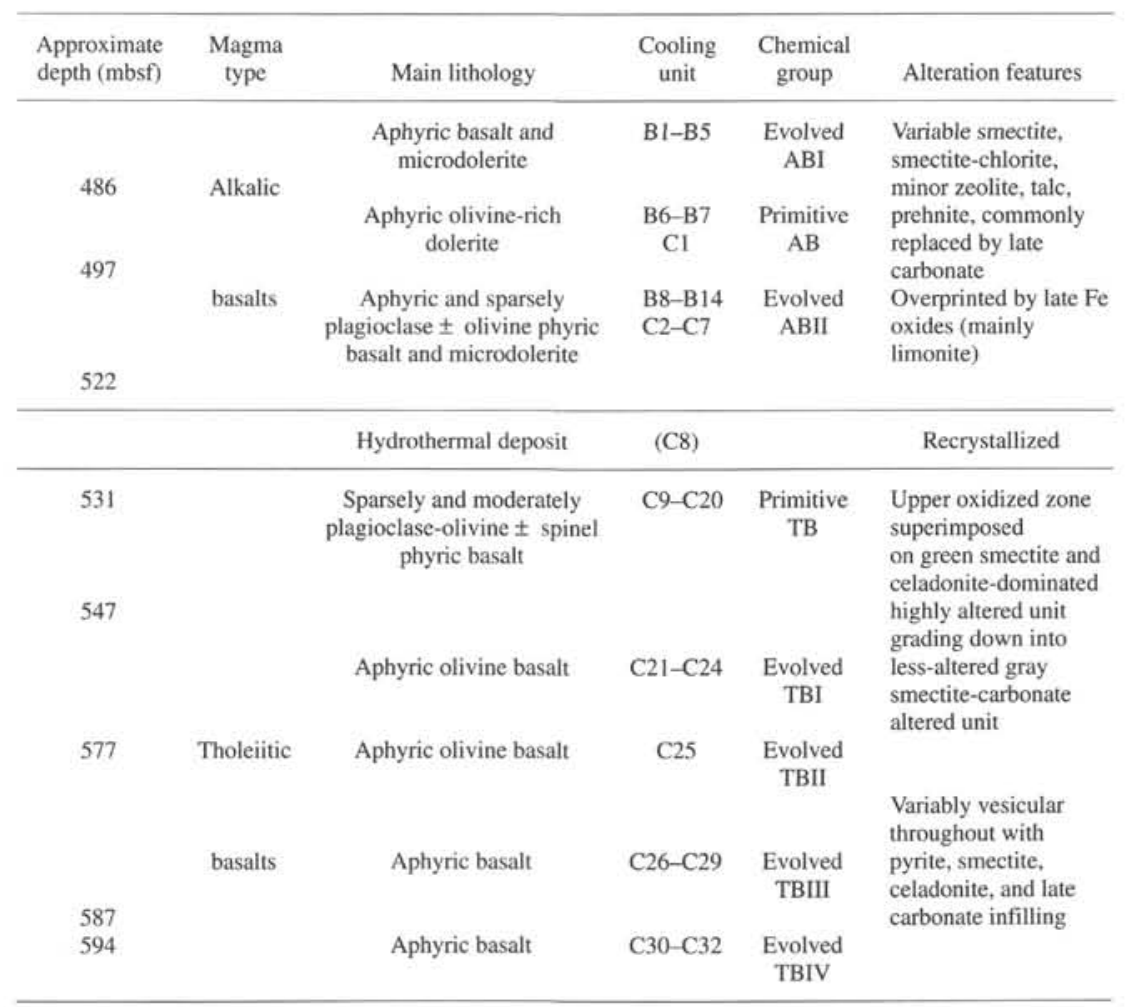

Note: Sequential cooling units from Hole $801 \mathrm{~B}$ labeled B1, B2, etc., and from Hole 801C, labeled C1, C2, etc. $\mathrm{AB}=$ alkalic basalts, $\mathrm{TB}=$ tholeiitic basalts .

the aphyric flows. The quenched top of this flow shows the sporadic isolated microphenocrysts of plagioclase, clinopyroxene, and olivine set in a matrix of plagioclase microlites, pyroxene variolitic fans, and remnants of altered glass. Plagioclase and clinopyroxene may form glomerocrystic groups with a poorly developed subophitic texture of radially disposed, serrated plagioclase crystals growing from a central nucleus of clinopyroxene grains. About $2-3 \mathrm{~m}$ from the top contact the flow is truly aphyric, hypocrystalline, texturally uniform, and vesicular. The matrix is composed of small olivine grains scattered throughout an intersertal texture of anhedral clinopyroxene grains grown between interlocking, serrated plagioclase laths. Growth centers of poorly subophitic clinopyroxene and plagioclase may also be common, similar to that seen in the variolitic zone above, but generally coarser in grain size. The grain size increases towards the center of the flow, although the textural mixture of anhedral clinopyroxene grains and serrated plagioclase laths, together with the subophitic growth centers, remains the same. Dark, smectite-replaced mesostasis is observed throughout the flow and is characterized by the abundance of magnetite granules, which are concentrated here rather than in the matrix. The mineralogical uniformity of this thick flow is also matched by its chemical composition, which shows little variation throughout the thickness of the flow (see the following).

The phyric tholeiites are concentrated directly below the hydrothermal deposit (units C9-C20) and are characterized by the phenocryst assemblage of olivine-plagioclase with variable spinel. They are commonly quenched textured throughout, hypocrystalline, and nonvesicular and represent the most primitive group of tholeiites sampled at Site 801. Plagioclase generally forms individual megaphenocrysts (1-4 mm long) or loose clumps in medium-grained glomerophyric groups. Spinel occurs as small (about $0.1 \mathrm{~mm}$ diameter), dark brown, euhedral octahedra generally scattered throughout the matrix or as minute grains within plagioclase phenocrysts. Olivine also forms small (about $0.2 \mathrm{~mm}$ ) equant, euhedral microphe- nocrysts that are totally replaced by smectites, and in some samples, by carbonate. In the flow margins the quench texture is typically spherulitic or variolitic with numerous plagioclase microlites exhibiting crystal-end extensions and a magnetite-peppered plumous matrix of incipient pyroxene and glass. Flow interiors may exhibit both spinel and olivine microphenocrysts set in a quenched matrix composed of serrated plagioclase crystals and intersertal clinopyroxene or coaxial plagioclase-clinopyroxene growths. One further texture that occurs sporadically is the development of coarser grained, early clinopyroxene crystals within a matrix dominated by clinopyroxene variolitic fans. Variation in the textures of flow interiors suggests that clinopyroxene probably grew at various stages-before, at the same time, and after the associated quenched plagioclase.

\section{ALTERATION}

As a result of reaction with penetrating seawater, the oceanic crust undergoes mineralogical and chemical alteration that can have a significant effect on the physical properties of the basaltic basement, buffer the composition of seawater, and be instrumental in the formation of metalliferous deposits. In general, two recognized processes take place under different thermal regimes (e.g., Honnorez, 1981; Thompson, 1983): (1) low-temperature oxidative alteration $\left(<70^{\circ}-\right.$ $\left.100^{\circ} \mathrm{C}\right)$ and $(2)$ higher temperature anoxic alteration $\left(>70^{\circ} \mathrm{C}\right.$, up to $400^{\circ} \mathrm{C}$ ). The former presents the pervasive, essentially ubiquitous, "submarine weathering" of the basaltic crust, whereas the latter is typical of more localized "hydrothermal" alteration due to the convective discharge of heated seawater in active axial zones. As the oldest oceanic crust penetrated so far, Site 801 provided the opportunity to compare the nature and type of alteration with younger analogues, and also to consider whether the oceanic crust progressively "ages" with time (Hart, 1976). 

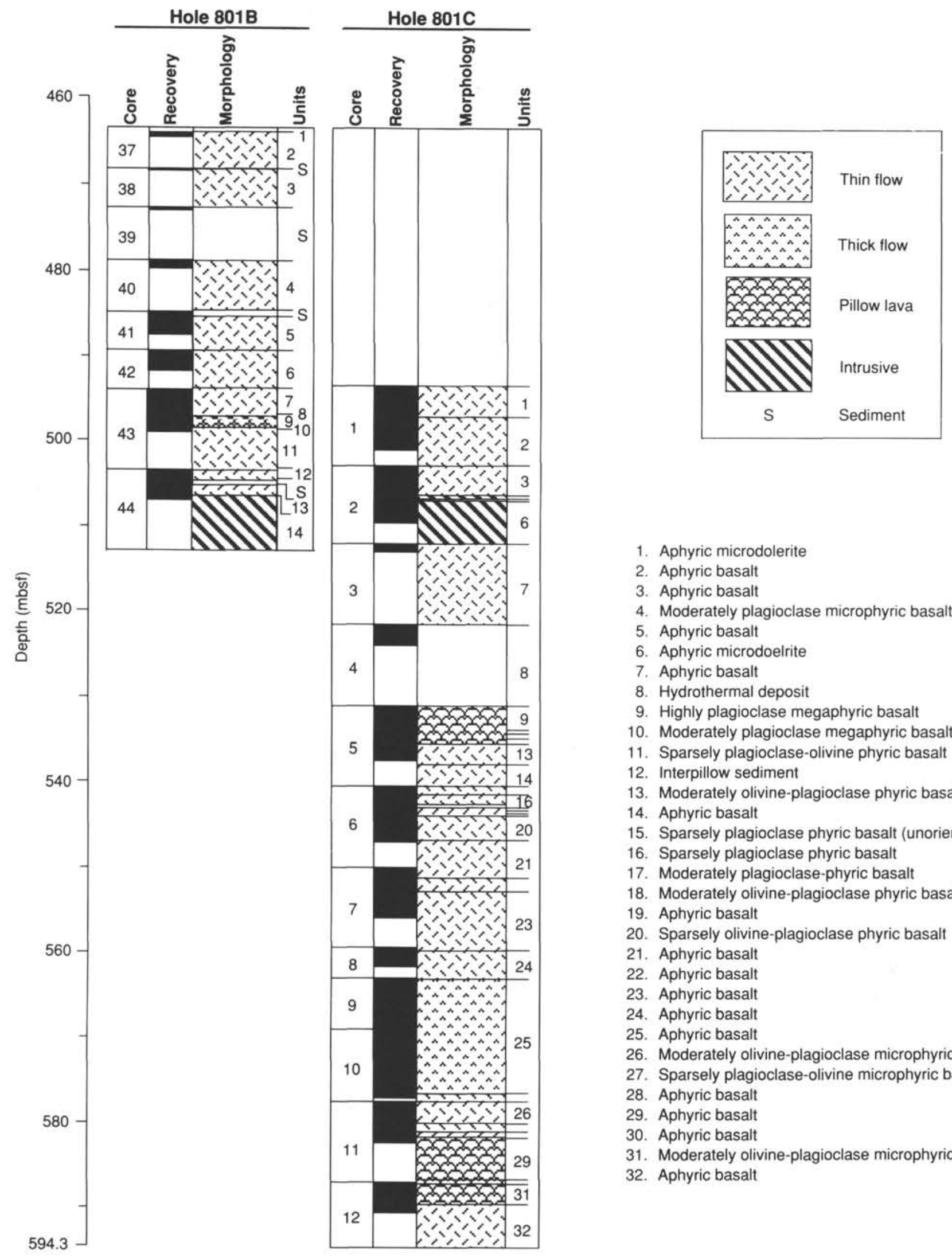

1. Aphyric microdolerite

2. Aphyric basalt

3. Aphyric basalt

4. Moderately plagioclase microphyric basalt

5. Aphyric basalt

6. Aphyric microdoelrite

7. Aphyric basalt

8. Hydrothermal deposit

9. Highly plagioclase megaphyric basalt

10. Moderately plagioclase megaphyric basalt

11. Sparsely plagioclase-olivine phyric basalt

12. Interpillow sediment

13. Moderately olivine-plagioclase phyric basalt

14. Aphyric basalt

15. Sparsely plagioclase phyric basalt (unoriented)

16. Sparsely plagioclase phyric basalt

17. Moderately plagioclase-phyric basalt

18. Moderately olivine-plagioclase phyric basalt

19. Aphyric basalt

20. Sparsely olivine-plagioclase phyric basalt

21. Aphyric basalt

22. Aphyric basalt

23. Aphyric basalt

24. Aphyric basalt

25. Aphyric basalt

26. Moderately olivine-plagioclase microphyric basalt

27. Sparsely plagioclase-olivine microphyric basalt

28. Aphyric basalt

29. Aphyric basalt

30. Aphyric basalt

31. Moderately olivine-plagioclase microphyric basalt

32. Aphyric basalt

Figure 2. Basalt lithostratigraphy of Holes $801 \mathrm{~B}$ and $801 \mathrm{C}$ (Lancelot, Larson, et al., 1990), 

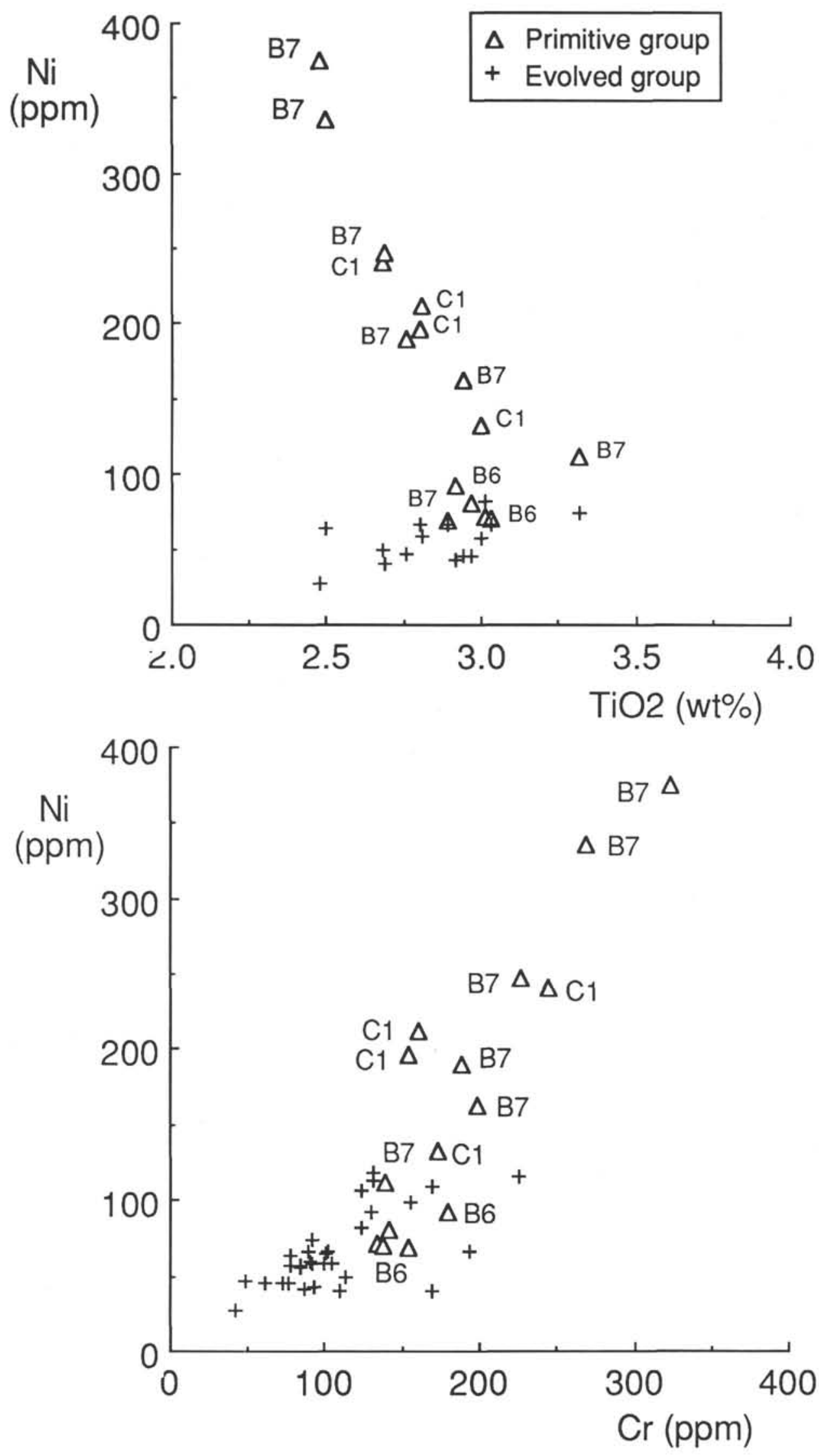

Figure 3. Chemical correlation between cooling units $\mathrm{B} 6$ and $\mathrm{B} 7$ of Hole $801 \mathrm{~B}$ with cooling unit $\mathrm{Cl}$ of Hole $801 \mathrm{C}$, which are distinguished from adjacent cooling units in both holes by steep trends exhibiting high $\mathrm{Ni}$ and $\mathrm{Cr}$ contents. 
The following provides a brief outline of the main alteration features exhibited by the Site 801 basalts; further details and the chemistry of specific secondary phases are given elsewhere in this volume (Alt et al.; France-Lanord; Rowbotham and Floyd).

\section{Mineralogical Effects}

1. All the Site 801 basalts are altered to varying degrees (from mild to severe) and are characterized by low-grade assemblages composed of mainly smectite, celadonite, smectite-chlorite, carbonate, rare zeolites, and ubiquitous pyrite. Both the bulk rocks and subsequent cross-cutting veinlets show similar secondary mineral associations that developed under anoxic zeolite facies conditions. Oxidative alteration is generally limited and restricted to the lavas directly above and below the hydrothermal deposit, together with the uppermost portion of flows at the top of Hole $801 \mathrm{~B}$, which are reddened by the late development of limonite and hematite. There is no evidence for the extensive development of an oxidized top to the basement sequence, unlike the upper altered zone of Deep Sea Drilling Project (DSDP) Hole 504B (Costa Rica Rift), which exhibits considerable Fe-hydroxide development and low-grade celadonite-nontronite replacement (Alt et al., 1985), or at generally older sites (from DSDP Legs 37 and 49) along the Mid-Atlantic Ridge (Blanchard et al., 1976; Floyd and Tarney, 1979). The lack of a characteristic submarine weathering "brownstone facies" (Cann, 1979) may be related to the tightly packed nature of the flows at Site 801 coupled with the subsequent blanketing effect of rapid sedimentation (about $10 \mathrm{~m} / \mathrm{m} . \mathrm{y}$; Lancelot, Larson, et al., 1990) that partly insulated the basement from penetration by oxygenated seawater. In terms of the general overall alteration shown by the complete section at Site 801, Jurassic basement is not markedly more altered than much younger crust, which reinforces the notion that alteration takes places rapidly after crust formation and then essentially terminates (e.g., Staudigel et al., 1981) unless continued penetration of oxygenated seawater is allowed by the highly fractured nature of the crust or occurs at an exposed (non-sedimented) position on the ridge.

2. Alteration intensity is typically highly variable both between and within cooling units and is largely governed by textural variations (degree of crystallinity) and the nature of fracturing. Glassy spherulitic flow margins are invariably altered to brownish smectites with the relatively sparse preservation of earlier formed palagonite. Olivine is everywhere replaced by either brownish or greenish smectites, commonly crisscrossed by oxidized magnetite veinlets, or smectite-carbonate and, rarely, talc with scattered magnetite granules. Plagioclase phenocrysts may also be completely altered to smectites and carbonate in glassy margins, whereas microlites shielded by spherulite growth remain fresh. In flow interiors plagioclase exhibits only partial replacement by smectites, celadonite, and rarer zeolites and prehnite. Glassy mesostasis is altered to brown smectites, or sporadically zeolites, and may commonly be accompanied by late biotite. In the alkalic basalts this is magmatic in origin (rather than metamorphic), although its development appears to span late magmatic to early alteration stages, replacing smectite-altered glass in the mesostasis. Clinopyroxene and spinel are generally unaltered. Originally open fractures (commonly a few millimeters wide) have been filled with smectitic clays and some pyrite, both of which may be replaced by late quartz or carbonate. Several vein-filling episodes are exhibited by some of the larger multiple veins, as well as the presence of variably oriented, cross-cutting vein sets, although the mineralogy (smectites, carbonate, quartz, pyrite) is essentially the same.

3. Because the sampled basement section is too thin to show any significant changes in alteration assemblages with depth, the variation exhibited is mainly related to the position of the hydrothermal deposit. The most highly altered part of Site 801 occurs directly below the hydrothermal deposit (especially units $\mathrm{C} 9-\mathrm{C} 16$, about $10 \mathrm{~m}$ thick) and exhibits the following features: (1) flow units are commonly strongly colored green (containing between $30 \%-70 \%$ secondary phases) due to the extensive development of smectite-celadonite, (2) the top section of this alteration zone may also be oxidized and overprinted by a red coloration due to hematite-limonite development, (3) small (10-30 $\mathrm{mm}$ wide), irregular, subvertical brecciated zones that extend over a considerable depth (1-2 m observable distance) and bordered by highly altered margins. These features suggest that prior to oxidation, volatile-rich hydrothermal fluids explosively penetrated these flows and under the seal produced by the hydrothermal deposit above, extensively altered them. Within the basement section of the core, neither the hydrothermal deposit, nor the flows above appear to have been penetrated by similar brecciated zones. The highly altered green zone is replaced downward by less altered gray-colored flows within which smectite-carbonate is the typical alteration assemblage. Many of these flows (units $\mathrm{C} 20-\mathrm{C} 32$ ) contain pyrite-smectite- or carbonate-filled vesicles that are lacking in the highly altered flows above.

In general, there are three main alteration events that reflect the change from a predominantly anoxic low-temperature environment to a localized superimposed oxidative regime: (1) smectite-dominated background alteration and (2) fracture-related smectite-pyrite alteration-both of which may show a later stage replacement by carbonate - and finally (3) Fe-oxyhydroxide alteration related to the hydrothermal deposit and the minor downward penetration of flow tops by seawater. On the basis of the structure of submarine hydrothermal systems (such as that associated with Hole 504B; Alt et al., 1986), the generally low-grade of alteration indicates that the segment of Site 801 crust sampled was mainly a recharge region possibly on the flanks of the axial zone. Certainly the lack of typical high-temperature background alteration phases (e.g., epidote, actinolite) would suggest that Site 801 was probably outside or on the fringes of the main hydrothermal discharge zone. However, the presence of minor brecciated zones and the overlying hydrothermal deposit could also indicate that an active system was in operation at this site, and if it had discharged low-temperature Fe-rich waters, an alteration mineralogy characteristic of higher temperature systems would not have developed.

\section{Hydrothermal Deposit}

A bright yellow, irregularly banded, ochrous goethite deposit, partly replaced and cemented by quartz, occurs above the most highly altered flows at about 522-531 mbsf (Table 2). The goethite lamellae have a colloform-like texture composed of botryoidal, concentrically layered masses with a radiate fibrous structure. Much of the deposit has undergone subsequent recrystallization to produce more uniform areas of interlocking yellow platelets exhibiting star-shaped shrinkage cracks. The goethite is also replaced by a least two phases of secondary quartz that ramify the deposit as irregular veinlets. There are two possible origins for the deposit: (1) the Fe was originally deposited as colloidal oxyhydroxides from hydrothermally generated solutions or (2) it represents the totally oxidized remnant (gossan) of a hydrothermal sulfide deposit. The colloform textures, shrinkage cracks, and lack of any textural or mineralogical evidence for laminae of spheroidal sulfides suggest the former process, although the latter cannot be ruled out completely. The variable oxidation of hydrothermal Fe sulfide deposits by oxygenated seawater is a common process (e.g., Bonatti, 1975), although in this case the Fe deposit does not show any metal enrichment caused by scavenging during its formation from sulfides (Bonatti et al., 1976). The base of the flows directly above and the tops of the flows immediately below the deposit were oxidized at a demonstrably later time than the background smectite alteration and smectite-pyrite veining event. These features could suggest that wholesale oxidation of the hydrothermal deposit (and adjacent flows) took place at a late stage and certainly after the extrusion and burial by the younger flows. However, if originally deposited as an oxyhydroxide, then the late oxidation may reflect limited penetration by seawater that used the more open structure of the deposit as a migration pathway. 


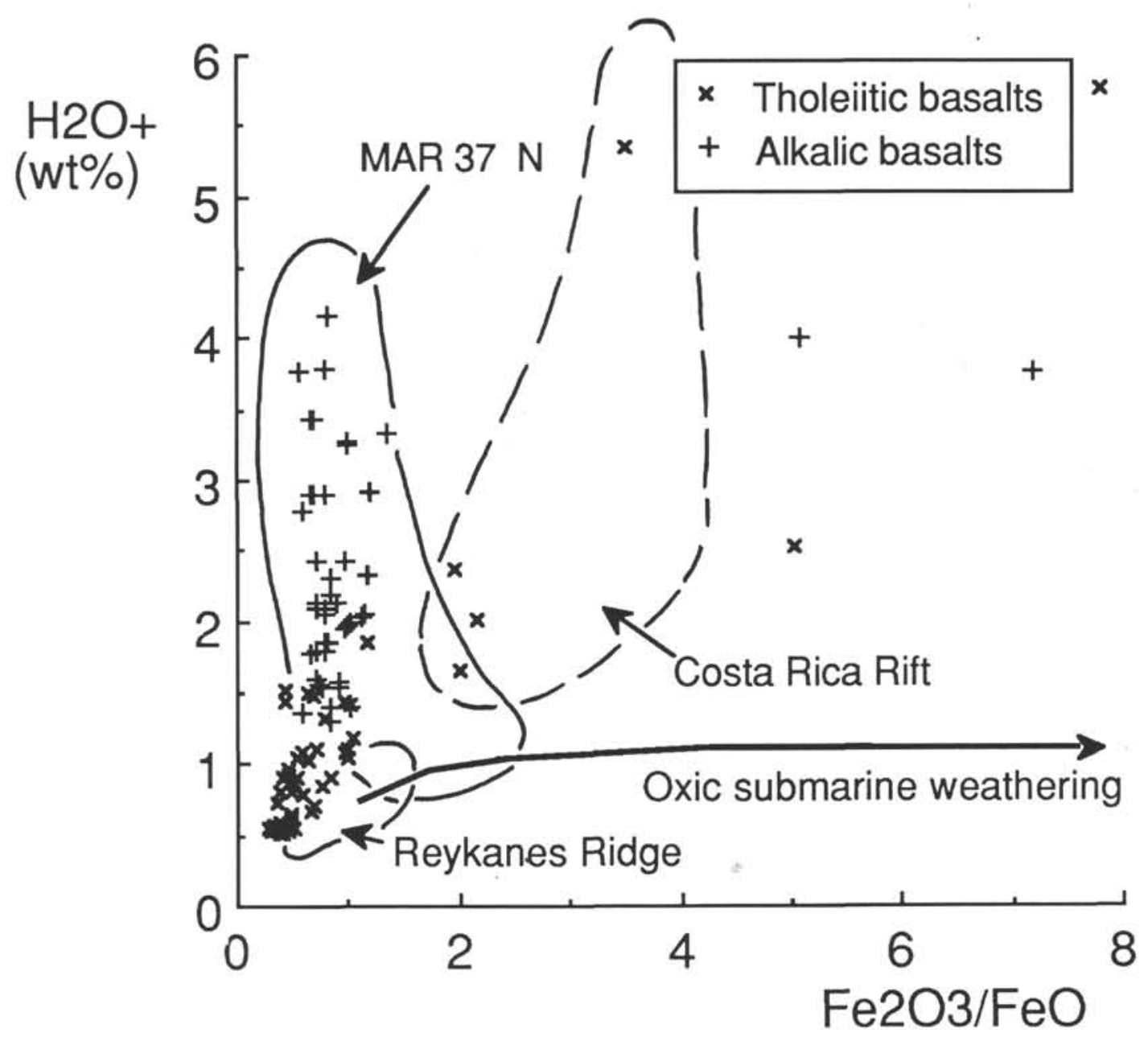

Figure 4. Relative degrees of hydration $\left(\mathrm{H}_{2} \mathrm{O}^{+}\right)$and oxidation $\left(\mathrm{Fe}_{2} \mathrm{O}_{3} / \mathrm{FeO}\right)$ shown by Site 801 basaltic rocks, compared with fresh MORB and alteration trends from the Reykjanes Ridge (Floyd and Tarney, 1979), Mid-Atlantic Ridge at $37^{\circ} \mathrm{N}$ (Blanchard et al., 1976), and the Costa Rica Rift (Alt and Emmermann, 1985).

Irrespective of its origin, the presence of this deposit at Site 801 indicates that a hydrothermal system was operative shortly after the formation of the Jurassic oceanic crust.

\section{Chemical Effects}

Chemical exchange during basalt-seawater interaction can cause considerable variability in the composition of basalts, such that under low-temperature alteration they can be hydrated $\left(\mathrm{H}_{2} \mathrm{O}^{+}\right.$increases), oxidized $\left(\mathrm{Fe}_{2} \mathrm{O}_{3} / \mathrm{FeO}\right.$ increases), gain large-ion-lithophile (LIL) elements, together with $\mathrm{B}$, and lose $\mathrm{Si}, \mathrm{Mg}, \mathrm{Ca}, \mathrm{Sr}$, and possibly $\mathrm{Na}$ (e.g., Hart et al., 1974; Humphris and Thompson, 1978; Thompson, 1983). In view of the extensive alteration by the hydrated secondary phases (especially directly below the hydrothermal deposit, units $\mathrm{C} 9-\mathrm{C} 16$ ), some chemical changes in the original magmatic composition of the Site 801 basalts are to be expected.

During the alteration process the majority of the Site 801 basalts have been extensively hydrated (with $\mathrm{H}_{2} \mathrm{O}^{+}$values ranging from $0.5 \%-4.2 \mathrm{wt} \%$ ) and carbonated (commonly $1-6 \mathrm{wt} \% \mathrm{CO}_{2}$ ) relative to fresh mid-ocean ridge basalt (MORB). In this respect they are similar to many basalts from the Mid-Atlantic Ridge at $37^{\circ} \mathrm{N}$ (Blanchard et al., 1976) and the Costa Rica Rift (Alt and Emmermann, $1985)$, although as a group they are characteristically less oxidized with $\mathrm{Fe}_{2} \mathrm{O}_{3} / \mathrm{FeO}$ generally $<1.0$ wt $\%$ (Fig. 4).
Although the basalt samples were not selected specifically to demonstrate chemical changes due to alteration, a number of general trends, or patterns, are evident within the complete data set that are a function of variable alteration (some examples are shown in Fig. 5):

1. Relative to progressive hydration (as measured by $\mathrm{H}_{2} \mathrm{O}^{+}$) $\mathrm{Ca}$, $\mathrm{Mg}$, and $\mathrm{Sr}$ decrease, whereas $\mathrm{K}, \mathrm{Rb}, \mathrm{Cs}, \mathrm{Ba}$, and $\mathrm{U}$ increase (cf. Thompson, 1983), although these effects become obvious and significantly change the basalt composition only if $\mathrm{H}_{2} \mathrm{O}^{+}$is greater than about $1.5 \mathrm{wt} \%$. Normalized rare earth element (REE) ratios, $\mathrm{La} / \mathrm{Sm}$ and $\mathrm{La} / \mathrm{Yb}$, show no change except for the most highly altered tholeiitic basalts with about $6 \mathrm{wt} \% \mathrm{H}_{2} \mathrm{O}^{+}(>12 \mathrm{wt} \% \mathrm{LOI})$, which exhibit very slight increases in the light REE (cf. Floyd, 1977; Ludden and Thompson, 1979). Major oxide ratios used as fractionation indices, such as $\mathrm{FeO} * / \mathrm{MgO}$, also increase with hydration (due to loss of $\mathrm{Mg}$ ), but significantly only in the tholeiites (Fig. 5).

2. Covariant relationships between magmatically coherent elements, such as pairs of incompatible elements, are disturbed by alteration. As seen in Figure 5 the behavior of both $\mathrm{Rb}$ and $\mathrm{Sr}$ relative to a stable element such as $\mathrm{Zr}$ shows nonmagmatic distributions and the disruption of linear trends typical of fresh basalts (cf. Wood et al., 1976).

3. Variation of alteration parameters with depth in the basement, such as $\mathrm{H}_{2} \mathrm{O}^{+}, \mathrm{CO}_{2}$, and total $\mathrm{S}$ (that in mineralogical terms represent 
the distribution of hydrated phyllosilicates, carbonate, and pyrite, respectively), are largely governed by fluid ponding under the hydrothermal deposit and the distribution of vein material. Within the tholeiitic section of the basement, the highest values of $\mathrm{H}_{2} \mathrm{O}^{+}$and $\mathrm{CO}_{2}$ are found below the hydrothermal deposit, although considerable variability below this depth is governed by the local development of smectite-carbonate veins, as well as a few highly hydrated flow tops. The alkalic basalt sequence above the hydrothermal deposit exhibits markedly higher $\mathrm{H}_{2} \mathrm{O}^{+}$contents than the tholeiites below, as a consequence of the presence of abundant primary biotite (and minor amphibole), as well as secondary hydrated phases. Sulfur abundances are overall higher and more variable in the tholeiitic sequence as a result of the presence of abundant pyrite-bearing veinlets. However, some of the tholeiitic flows directly below the hydrothermal deposit show a depletion in $\mathrm{S}$ due to the oxidation of pyrite.

\section{Summary}

The alteration of Site 801 basalts is highly variable and heterogeneous on a small scale (centimeter to meter), and no systematic variations are seen with depth apart from the highly hydrated and carbonated flows directly below the hydrothermal deposit and the concentration of vein pyrite in the lower tholeiites. Low-grade alteration assemblages (typically smectite, celadonite, carbonate, zeolites, and pyrite) are similar throughout the basement sequence and are apparently not influenced by basalt type. Element mobility has involved mainly LIL elements, although this is not very severe and most elements broadly retain distribution patterns that can be attributed to magmatic processes. Alteration was essentially anoxic with low water/rock ratios and possibly developed in a ridge flank related to an active hydrothermal system.

\section{GEOCHEMISTRY AND PETROGENESIS}

In this section we outline the general chemical features and interrelationships of the basement flows that comprise the upper alkalic basalt sequence and the lower tholeiitic basalt sequence at Site 801. Major oxide and trace element data for Holes 801B and 801C are represented in Tables 3 and 4, respectively (isotope data are presented by Castillo et al., this volume).

\section{General Characteristics}

The tholeiitic and alkalic basalts display many of the chemical features characteristic of these two magma types, and in this case are distinguished by the following: (1) the tholeiites are predominantly hypersthene-normative, whereas the alkalic basalts are nepheline-normative (Fig. 6), (2) the alkalic basalts have consistently higher incompatible element abundances over the same range of chemical evolution, for example, $\mathrm{TiO}_{2}$ distributions (Fig. 7), and (3) chondrite-normalized multi-element distributions exhibit depleted patterns for the tholeiites and strongly enriched patterns for the alkalic basalts (Fig. 8). Although magnesium numbers ( $\mathrm{Mg} *=[\mathrm{Mg} / \mathrm{Mg}+$ $\left.\mathrm{Fe}^{2+}\right] \times 100$ in atomic proportions) are similar on average and range, for the tholeiitic $(\mathrm{Mg} *=56 \pm 11)$ and alkalic basalts $\left(\mathrm{Mg}^{*}=55 \pm 7\right)$, the former contains a few relatively primitive tholeiites with values at about $\mathrm{Mg}^{*}=$ 70 . Excluding the most altered basalts in this group (hydration decreases $\mathrm{MgO}$ and thus, $\mathrm{Mg}$ * values), $\mathrm{MgO}$ (7-9 wt\%), $\mathrm{Ni}(>200 \mathrm{ppm})$, and $\mathrm{Cr}$ $(>450 \mathrm{ppm})$ are high and coupled with low $\mathrm{TiO}_{2}(<1 \mathrm{wt} \%)$ and other incompatible elements, and approach some of the most "primitive" values recorded for oceanic basalts (e.g., Basaltic Volcanism Study Project, 1981). In general the tholeiites have features characteristic of depleted or normaltype mid-ocean ridge basalt (N-MORB), whereas the alkalic basalts are similar to average ocean island basalt (OIB) (Floyd et al., 1991).

\section{Chemostratigraphy}

Apart from the alkalic and tholeiitic sequences, downhole variation, as monitored by a stable element such as $\mathrm{Zr}$, allows the recognition of both primitive and evolved chemical groups that represent packets of cooling units separated by major chemical breaks (Fig. 9 and Table 2). The primitive group of the alkalic basalts (with high $\mathrm{MgO}, \mathrm{Ni}$, and $\mathrm{Cr}$ ) is represented by the olivine-rich aphyric dolerites (cooling units B6-B7 and $\mathrm{C1}$ ), whereas the most primitive tholeiitic group comprise the spinel-olivine-plagioclase phyric basalts directly below the hydrothermal deposit (cooling units $\mathrm{C} 9-\mathrm{C} 20$ ), which also has the highest $\mathrm{Mg} *$ values. The more evolved tholeiitic basalts (chemical groups I to IV) have higher Zr contents and lower $\mathrm{Cr}$ and $\mathrm{Ni}$, although ratios of incompatible elements (e.g., $\mathrm{Zr} / \mathrm{Y}$, $\mathrm{La} / \mathrm{Nb}$ ) are generally constant and similar to the primitive group (Fig. 9). The basal chemical group (IV) has the highest $\mathrm{Zr}$ content and corresponds to the most fractionated tholeiites (containing minor clinopyroxene phenocrysts) relative to the olivine-bearing less-fractionated tholeiites above (chemical group I). Overall, however, there is not a simple monotonic relationship of increasing fractionation with depth, from primitive group to most-evolved group tholeiites, as each chemical group has its own relatively uniform and distinctive composition.

\section{Lower Tholeiitic Sequence}

Both the primitive and evolved groups have chemical features typical of N-MORB: (1) Mg* commonly within the range of 50-60 (Fig. 10), (2) low absolute abundances of incompatible elements, for example, $\mathrm{TiO}_{2}$ $<2.50 \mathrm{wt} \%$, Hf $<3.5 \mathrm{ppm}, \mathrm{Sr}<200 \mathrm{ppm}$, and $\mathrm{Zr}<150 \mathrm{ppm}$, (3) characteristic ratios of stable incompatible elements, such as low $\mathrm{Zr} / \mathrm{Y}$ (about 2.0-3.5), $\mathrm{La} / \mathrm{Nb}$ (about $0.5-1.0$ ), and $\mathrm{Th} / \mathrm{Ta}$ (about $0.5-1.5$ ) coupled with high $\mathrm{Ti} / \mathrm{Zr}$ (about $100-120$ ) and $\mathrm{Zr} / \mathrm{Nb}$ (about 18-20); and (4) chondritenormalized light REE-depleted patterns (Fig. 11) with $(\mathrm{La} / \mathrm{Yb})_{\mathrm{N}}$ about $0.4-0.6$.

Chemical relationships between the different groups, recognized relative to depth at Site 801 , indicate that they could represent a single comagmatic suite ranging from primitive $\left(\mathrm{Mg}^{*}=70\right)$ to moderately well-evolved $\left(\mathrm{Mg}^{*}=45\right)$ compositions. Using $\mathrm{Zr}$ as a stable fractionation index, Figure 12 shows that $(1) \mathrm{TiO}_{2}$ and $\mathrm{Y}$ define a single trend or simple positive covariance (other incompatible elements show a similar relationship), whereas (2) $\mathrm{Cr}$ and $\mathrm{Ni}$ show steep and progressively decreasing abundance trends (other compatible ferromagnesian elements show similar trends). The range of elemental composition, with progressively increasing incompatible elements coupled with decreasing ferromagnesian element abundances, suggests that all the tholeiites could be related via variable mafic phase fractionation. The marked decrease in $\mathrm{Ni}$ and $\mathrm{Cr}$ in the primitive tholeiites reflect the influence of early olivine and spinel fractionation, respectively, whereas the less-steep trends developed by the evolved tholeiites are largely governed by plagioclase-olivine and possibly minor clinopyroxene fractionation. REE patterns for the primitive and evolved chemical groups are essentially parallel (Fig. 11) such that they all have a similar degree of light-to-heavy REE fractionation. This implies that all groups are related mainly by the fractionation of olivine and/or plagioclase (representing major crystallizing phases that do not fractionate the REE) and that clinopyroxene fractionation was of minor significance. However, the basalts had not proceeded to the stage where the significant removal of plagioclase (of more intermediate composition than observed) produces a negative Eu anomaly.

Ratios of highly-to-mildly incompatible elements (e.g., $\mathrm{Zr} / \mathrm{Y})$ and between highly incompatible elements (e.g., Th/Ta) are also similar throughout the tholeiites and indicate that the chemical variation is not a consequence of variable partial melting or different mantle source compositions. These chemical features indicate that a singlesource composition (also supported by the isotope data; Castillo et al., this volume) melted to produce a (relatively primitive) partial melt that was parental to all the tholeiites, both primitive and evolved groups. The spread of data, therefore, points to the existence of a single fractionated tholeiitic suite and implies the presence of a high-level, chemically stratified, crustal magma chamber that was progressively tapped, venting a range of compositions from wellevolved to primitive with time. However, the marked chemical breaks observed with depth (Fig. 9) and the gaps in the incompatible element 
Table 3. Chemical analyses of basaltic rocks from Hole 801B.

\begin{tabular}{|c|c|c|c|c|c|c|c|c|c|c|c|c|c|c|c|}
\hline Core, section: & $38 \mathrm{R}-1$ & $40 \mathrm{R}-1$ & $40 \mathrm{R}-1$ & $40 \mathrm{R}-1$ & $41 R-1$ & $41 R-1$ & $41 \mathrm{R}-1$ & $41 \mathrm{R}-2$ & $41 \mathrm{R}-2$ & $42 \mathrm{R}-1$ & $42 R-1$ & $42 \mathrm{R}-2$ & $42 \mathrm{R}-2$ & $43 R-1$ & $43 R-1$ \\
\hline Interval $(\mathrm{cm})$ : & $22-25$ & $15-18$ & $29-33$ & $85-91$ & $26-31$ & $88-94$ & $130-136$ & $20-25$ & $103-109$ & $24-30$ & $87-91$ & $0-7$ & $129-134$ & $4-9$ & $16-20$ \\
\hline Depth (mbsf): & 466.32 & 477.05 & 477.19 & 477.75 & 483.26 & 483.88 & 484.30 & 484.70 & 485.53 & 487.84 & 488.47 & 489.05 & 490.34 & 492.24 & 492.36 \\
\hline Cooling unit: & B3 & B4 & B4 & B4 & B5 & B5 & B5 & B5 & B5 & B6 & B6 & B6 & B6 & B7 & B7 \\
\hline \multicolumn{16}{|c|}{ Major oxides (wt\%) } \\
\hline $\mathrm{SiO}_{2}$ & 51.45 & 51.58 & 53.20 & 39.67 & 45.77 & 46.36 & 46.08 & 46.33 & 46.36 & 47.08 & 46.50 & 46.91 & 46.33 & 46.44 & 44.86 \\
\hline $\mathrm{TiO}_{2}^{-}$ & 2.67 & 3.30 & 3.58 & 2.70 & 3.31 & 3.27 & 3.24 & 3.56 & 3.07 & 3.03 & 3.01 & 2.89 & 2.92 & 2.97 & 2.76 \\
\hline $\mathrm{Al}_{2} \mathrm{O}_{3}$ & 18.62 & 17.42 & 18.96 & 14.02 & 16.03 & 15.89 & 15.80 & 15.14 & 16.61 & 17.32 & 17.23 & 17.42 & 16.96 & 17.04 & 14.82 \\
\hline $\mathrm{Fe}_{2} \mathrm{O}_{3}$ & 5.97 & 9.02 & 5.54 & 3.57 & 4.76 & 3.80 & 4.28 & 4.27 & 4.32 & 4.91 & 5.04 & 4.63 & 4.04 & 4.25 & 4.52 \\
\hline $\mathrm{FeO}$ & 0.61 & 0.75 & 0.77 & 3.92 & 4.72 & 5.37 & 5.79 & 5.57 & 5.40 & 4.39 & 4.31 & 4.68 & 5.70 & 5.43 & 5.78 \\
\hline $\mathrm{MnO}$ & 0.04 & 0.12 & 0.08 & 0.23 & 0.14 & 0.13 & 0.15 & 0.14 & 0.14 & 0.14 & 0.14 & 0.14 & 0.14 & 0.13 & 0.14 \\
\hline $\mathrm{MgO}$ & 4.69 & 2.75 & 2.87 & 4.11 & 5.20 & 5.07 & 4.86 & 4.52 & 4.79 & 5.68 & 6.26 & 6.50 & 7.18 & 6.98 & 8.49 \\
\hline $\mathrm{CaO}$ & 2.00 & 2.63 & 1.88 & 14.27 & 8.25 & 7.82 & 7.64 & 7.71 & 7.76 & 8.29 & 8.26 & 8.36 & 8.06 & 7.83 & 7.01 \\
\hline $\mathrm{Na}_{2} \mathrm{O}$ & 2.04 & 2.91 & 2.76 & 3.83 & 3.81 & 3.64 & 3.71 & 3.88 & 3.60 & 3.64 & 3.49 & 3.43 & 3.26 & 3.42 & 3.82 \\
\hline $\mathrm{K}_{2} \mathrm{O}$ & 5.80 & 5.88 & 5.84 & 1.74 & 2.14 & 2.45 & 2.61 & 3.01 & 2.54 & 2.20 & 1.97 & 1.96 & 1.82 & 1.88 & 1.79 \\
\hline $\mathrm{P}_{2} \mathrm{O}_{5}$ & 0.36 & 0.63 & 0.67 & 0.56 & 0.62 & 0.69 & 0.61 & 0.69 & 0.59 & 0.59 & 0.56 & 0.54 & 0.56 & 0.55 & 0.57 \\
\hline LOI & 5.67 & 2.68 & 4.12 & 10.92 & 5.09 & 4.72 & 4,71 & 4.67 & 4.95 & 3.14 & 3.34 & 2.93 & 2.85 & 2.70 & 5.14 \\
\hline Total & 99.93 & 99.66 & 100.26 & 99.54 & 99.83 & 99.21 & 99.48 & 99.48 & 100.14 & 100.22 & 100.11 & 100.40 & 99.81 & 99.61 & 99.70 \\
\hline $\mathrm{H}_{2} \mathrm{O}+$ & 4.81 & 2.72 & 3.77 & 1.54 & 2.00 & 1.60 & 1.55 & 1.54 & 1.86 & 2.04 & 2.32 & 1.97 & 2.09 & 2.06 & 3.78 \\
\hline $\mathrm{CO}_{2}$ & 0.71 & 0.11 & 0.24 & 9.45 & 2.83 & 2.76 & 3.00 & 2.90 & 2.96 & 0.97 & 0.97 & 1.07 & 0.85 & 0.76 & 0.86 \\
\hline
\end{tabular}

Trace elements by XRF (ppm)

\begin{tabular}{|c|c|c|c|c|c|c|c|c|c|c|c|c|c|c|c|}
\hline $\mathrm{Ba}$ & 457 & 439 & 406 & 318 & 414 & 452 & 422 & 448 & 395 & 386 & 365 & 377 & 354 & 375 & 517 \\
\hline $\mathrm{Ce}$ & 52 & 88 & 75 & 77 & 70 & 65 & 82 & 78 & 73 & 55 & 48 & 58 & 59 & 66 & 57 \\
\hline $\mathrm{Cr}$ & 194 & 123 & 89 & 93 & 73 & 48 & 61 & 42 & 113 & 137 & 134 & 154 & 180 & 141 & 189 \\
\hline $\mathrm{Cu}$ & 64 & 37 & 20 & 24 & 44 & 47 & 44 & 44 & 40 & 40 & 42 & 37 & 39 & 39 & 41 \\
\hline $\mathrm{Ga}$ & 18 & 22 & 26 & 23 & 23 & 21 & 24 & 23 & 23 & 23 & 23 & 22 & 20 & 22 & 17 \\
\hline $\mathrm{La}$ & 36 & 39 & 39 & 38 & 30 & 29 & 39 & 27 & 32 & 25 & 18 & 29 & 26 & 30 & 27 \\
\hline $\mathrm{Nb}$ & 36 & 49 & 51 & 40 & 48 & 48 & 49 & 53 & 44 & 44 & 44 & 42 & 41 & 43 & 39 \\
\hline $\mathrm{Nd}$ & 43 & 49 & 42 & 41 & 41 & 41 & 39 & 29 & 42 & 33 & 26 & 30 & 33 & 34 & 33 \\
\hline $\mathrm{Ni}$ & 67 & 82 & 66 & 43 & 46 & 47 & 45 & 28 & 50 & 71 & 72 & 69 & 92 & 81 & 190 \\
\hline $\mathrm{Pb}$ & 1 & 6 & 1 & 9 & 3 & 2 & 10 & 9 & 8 & 3 & 2 & 8 & 7 & 8 & 2 \\
\hline $\mathrm{Rb}$ & 82 & 110 & 88 & 33 & 39 & 48 & 52 & 62 & 52 & 39 & 40 & 42 & 38 & 41 & 37 \\
\hline$S$ & 162 & 105 & 146 & 224 & 358 & 293 & 250 & 251 & 239 & 368 & 370 & 276 & 298 & 283 & 333 \\
\hline $\mathrm{Sr}$ & 102 & 317 & 134 & 654 & 518 & 503 & 512 & 486 & 526 & 571 & 548 & 572 & 559 & 564 & 509 \\
\hline V & 335 & 241 & 198 & 235 & 267 & 261 & 275 & 301 & 252 & 236 & 230 & 234 & 218 & 230 & 214 \\
\hline $\mathrm{Y}$ & 20 & 33 & 27 & 30 & 32 & 32 & 32 & 36 & 30 & 29 & 29 & 29 & 28 & 29 & 27 \\
\hline $\mathrm{Zn}$ & 93 & 111 & 74 & 64 & 90 & 89 & 90 & 101 & 85 & 89 & 79 & 72 & 71 & 76 & 86 \\
\hline $\mathrm{Zr}$ & 194 & 153 & 208 & 229 & 272 & 280 & 285 & 308 & 256 & 247 & 246 & 243 & 233 & 245 & 230 \\
\hline
\end{tabular}

\begin{tabular}{|c|c|c|c|c|c|c|c|c|c|c|c|c|c|c|c|}
\hline \multicolumn{16}{|c|}{ Trace elements by INAA (ppm) } \\
\hline Cs & 1.33 & 3.31 & - & 0.31 & 0.29 & - & 0.39 & 0.47 & - & - & - & 0.29 & 0.24 & - & - \\
\hline $\mathrm{Hf}$ & 4.19 & 3.64 & - & 5.34 & 5.92 & - & 6.40 & 7.50 & - & - & - & 5.8 & 5.3 & - & - \\
\hline $\mathrm{Sc}$ & 28.2 & 11.69 & - & 18.6 & 22.5 & - & 25.2 & 28.6 & - & - & - & 22.6 & 20.1 & - & - \\
\hline $\mathrm{Ta}$ & 2.47 & 3.17 & - & 2.69 & 3.17 & - & 3.23 & 3.49 & - & - & - & 2.76 & 2.80 & - & - \\
\hline $\mathrm{Th}$ & 2.00 & 3.16 & - & 2.58 & 3.02 & - & 3.50 & 3.60 & - & - & - & 3.00 & 2.57 & - & - \\
\hline U & 1.18 & 0.78 & - & 1.39 & 1.40 & - & 1.01 & 1.04 & - & - & - & 1.00 & 0.89 & - & - \\
\hline \multicolumn{16}{|c|}{ Rare earth elements (ppm) } \\
\hline $\mathrm{La}$ & 20.3 & 30.1 & - & 29.7 & 30.5 & - & 36.30 & 39.61 & - & - & - & 32.44 & 27.60 & - & - \\
\hline $\mathrm{Ce}$ & 43.0 & 59.1 & - & 61.3 & 63.8 & - & 74.16 & 81.76 & - & - & - & 64.95 & 58.40 & - & - \\
\hline $\operatorname{Pr}$ & - & - & - & - & - & - & 8.65 & 9.36 & - & - & - & 7,48 & 20.00 & - & - \\
\hline $\mathrm{Nd}$ & 21.0 & 28.0 & - & 29.0 & 31.0 & - & 35.47 & 39.08 & - & - & - & 31.41 & 25.00 & - & - \\
\hline $\mathrm{Sm}$ & 4.17 & 6.88 & - & 6.80 & 7.28 & - & 7.41 & 8.22 & - & - & - & 6.62 & 6.62 & - & - \\
\hline Eu & 1.32 & 2.17 & - & 2.15 & 2.32 & - & 2.47 & 2.69 & - & - & - & 2.22 & 2.09 & - & - \\
\hline Gid & - & - & - & - & - & - & 7.23 & 8.05 & - & - & - & 6.58 & - & - & - \\
\hline $\mathrm{Tb}$ & 0.607 & 0.923 & - & 0.97 & 1.03 & - & - & - & - & - & - & - & 0.89 & - & - \\
\hline Dy & - & - & - & - & - & - & 6.40 & 7.00 & - & - & - & 5.68 & - & - & - \\
\hline Ho & - & - & - & - & - & - & 1.14 & 1.22 & - & - & - & 1.02 & - & - & - \\
\hline $\mathrm{Er}$ & - & - & - & - & - & - & 3.11 & 3.36 & - & - & - & 2.71 & - & - & - \\
\hline $\mathrm{Yb}$ & 1.69 & 1,84 & - & 2.20 & 2.31 & - & 2.60 & 2.82 & - & - & - & 2.26 & 2.18 & - & - \\
\hline $\mathrm{Lu}$ & 0.241 & 0.254 & - & 0.310 & 0.315 & - & 0.44 & 0.44 & - & - & - & 0.38 & 0.303 & - & - \\
\hline
\end{tabular}

Note: $\mathrm{LOI}=$ Loss on ignition $\left(\right.$ at $1200^{\circ} \mathrm{C}$ ).

covariance with $\mathrm{Zr}$ (Fig. 12) suggest that the basalts are not the product of simple closed-system fractionation. Instead, it is considered that each chemical group developed its chemical identity via mixing between resident (variably fractionated) melts in the magma chamber and influxes of new (more primitive) melts, together with subsequent fractionation prior to venting on the seafloor.

This model is similar to open-system fractionation (O'Hara and Mathews, 1981) and represents the simplest chemical scheme for linking the basaltic compositions. However, it cannot be entirely ruled out that both primitive and evolved magmas may have come from several, very similar, fractionating, penecontemporaneous systems, deriving melts from a uniform mantle source. Also, there is no reason to suppose that Site 801 only sampled a single magma system with flows being derived from one vent on the ocean floor, instead of multiple derivation over a considerable area. However, in view of the chemical (and isotopic) coherence of the basalts we prefer the simpler model and suggest the 
Table 3 (continued).

\begin{tabular}{|c|c|c|c|c|c|c|c|c|c|c|c|c|c|c|c|}
\hline Core, section: & $43 R-1$ & $43 R-1$ & $43 R-2$ & $43 R-2$ & $43 R-3$ & $43 R-3$ & $43 R-4$ & $43 R-4$ & $44 \mathrm{R}-1$ & $44 \mathrm{R}-1$ & $44 \mathrm{R}-2$ & $44 \mathrm{R}-2$ & $44 \mathrm{R}-2$ & $44 \mathrm{R}-3$ & $44 \mathrm{R}-3$ \\
\hline Interval $(\mathrm{cm})$ : & $22-27$ & $128-134$ & $10-15$ & $21-27$ & $23-27$ & $126-129$ & $5-10$ & $32-40$ & $18-24$ & $107-113$ & $27-32$ & $67-72$ & $140-145$ & $13-22$ & $28-33$ \\
\hline Depth (mbsf): & 492.42 & 493.48 & 493.67 & 493.78 & 495.21 & 496.24 & 496.53 & 496.80 & 501.88 & 502.77 & 503.42 & 503.82 & 504.55 & 504.76 & 504.91 \\
\hline Cooling unit: & B7 & B7 & B7 & B7 & B7 & B9 & $\mathrm{B} 10$ & B11 & $\mathrm{B} 12$ & $\mathrm{~B} 12$ & B13 & $\mathrm{B} 13$ & $\mathrm{~B} 13$ & B14 & B14 \\
\hline \multicolumn{16}{|c|}{ Major oxides (wt\%) } \\
\hline $\mathrm{SiO}_{2}$ & 45.88 & 44.43 & 44.88 & 44.38 & 47.46 & 42.82 & 47.20 & 45.22 & 44.87 & 48.13 & 51.42 & 45,67 & 48.57 & 49.06 & 47.65 \\
\hline $\mathrm{TiO}_{2}$ & 2.94 & 2.48 & 2.68 & 2.50 & 3.32 & 2.85 & 3.08 & 3.38 & 3.26 & 3.26 & 3.27 & 3.12 & 3.31 & 3.25 & 3.16 \\
\hline $\mathrm{Al}_{2} \mathrm{O}_{3}$ & 15.23 & 13.11 & 14.46 & 13.67 & 17.48 & 15.40 & 16.83 & 17.32 & 16.80 & 17.72 & 17.70 & 17.02 & 17.46 & 17.87 & 17.22 \\
\hline $\mathrm{Fe}_{2} \mathrm{O}_{3}$ & 4.70 & 5.73 & 4.86 & 4.95 & 3.67 & 3.20 & 4.11 & 5.20 & 3.76 & 4.32 & 3.75 & 4.28 & 4.48 & 4.19 & 4.18 \\
\hline $\mathrm{FeO}$ & 5.70 & 5.72 & 6.20 & 5.16 & 5.53 & 3.84 & 4.59 & 5.20 & 4.16 & 3.22 & 3.27 & 4.38 & 4.46 & 4.99 & 5.04 \\
\hline $\mathrm{MnO}$ & 0.13 & 0.15 & 0.16 & 0.16 & 0.20 & 0.49 & 0.20 & 0.20 & 0.31 & 0.18 & 0.13 & 0.20 & 0.13 & 0.11 & 0.14 \\
\hline $\mathrm{MgO}$ & 8.28 & 10.58 & 9.01 & 8.93 & 3.98 & 3.31 & 3.58 & 4.09 & 2.65 & 3.05 & 3.03 & 3.99 & 4.08 & 3.69 & 4.21 \\
\hline $\mathrm{CaO}$ & 6.21 & 6.59 & 6.74 & 7.38 & 3.38 & 9.01 & 6.15 & 6.24 & 9.37 & 4.35 & 3.56 & 7.95 & 7.02 & 6.47 & 7.24 \\
\hline $\mathrm{Na}_{2} \mathrm{O}$ & 4.02 & 2.76 & 3.35 & 3.12 & 2.78 & 2.89 & 3.84 & 4.61 & 4.01 & 3.12 & 3.20 & 4.21 & 4.23 & 4.47 & 4.08 \\
\hline $\mathrm{K}_{2} \mathrm{O}$ & 1.90 & 1.46 & 1.79 & 1.63 & 4.95 & 4.55 & 3.27 & 2.34 & 2.94 & 4.57 & 5.67 & 1.88 & 1.88 & 2.15 & 2.31 \\
\hline $\mathrm{P}_{2} \mathrm{O}_{5}$ & 0.55 & 0.46 & 0.50 & 0.51 & 0.64 & 0.52 & 0.59 & 0.68 & 0.57 & 0.57 & 0.55 & 0.52 & 0.57 & 0.74 & 0.57 \\
\hline LOI & 4.58 & 6.16 & 5.21 & 7.22 & 6.22 & 10.63 & 6.82 & 5.85 & 7.69 & 6.96 & 4.38 & 6.79 & 4.35 & 3.46 & 3.65 \\
\hline Total & 100.12 & 99.63 & 99.85 & 99.61 & 99.60 & 100.51 & 100.27 & 100.32 & 100.41 & 99.45 & 99.95 & 100.01 & 100.55 & 100.45 & 99.43 \\
\hline $\mathrm{H}_{2} \mathrm{O}+$ & 4.17 & 3.27 & 2.91 & 2.42 & 2.91 & 2.30 & 2.14 & 3.26 & 1.57 & 3.34 & 2.06 & 1.95 & 1.40 & 1.30 & 1.40 \\
\hline $\mathrm{CO}_{2}$ & 0.35 & 2.46 & 2.02 & 3.94 & 3.05 & 8.69 & 4.20 & 2.36 & 5.50 & 3.24 & 2.20 & 4.36 & 2.69 & 2.14 & 2.05 \\
\hline
\end{tabular}

Trace elements by XRF

$\begin{array}{lrrrrrr}\text { (ppm) } & & & & & & \\ \mathrm{Ba} & 495 & 371 & 483 & 460 & 481 & 413 \\ \mathrm{Ce} & 51 & 42 & 57 & 40 & 72 & 52 \\ \mathrm{Cr} & 199 & 323 & 244 & 269 & 139 & 78 \\ \mathrm{Cu} & 39 & 35 & 33 & 35 & 37 & 36 \\ \mathrm{Ga} & 18 & 16 & 21 & 16 & 23 & 20 \\ \mathrm{La} & 17 & 21 & 20 & 24 & 31 & 26 \\ \mathrm{Nb} & 42 & 37 & 40 & 35 & 49 & 40 \\ \mathrm{Nd} & 26 & 26 & 26 & 23 & 35 & 25 \\ \mathrm{Ni} & 163 & 375 & 241 & 336 & 112 & 64 \\ \mathrm{~Pb} & 4 & 2 & 8 & 2 & 11 & 9 \\ \mathrm{Rb} & 40 & 32 & 39 & 33 & 67 & 58 \\ \mathrm{~S} & 379 & 1388 & 362 & 403 & 288 & 266 \\ \mathrm{Sr} & 384 & 372 & 413 & 399 & 266 & 243 \\ \mathrm{~V} & 237 & 204 & 202 & 206 & 277 & 212 \\ \mathrm{Y} & 28 & 25 & 27 & 25 & 28 & 31 \\ \mathrm{Zn} & 86 & 89 & 93 & 80 & 104 & 72 \\ \mathrm{Zr} & 244 & 208 & 227 & 209 & 277 & 218\end{array}$

$\begin{array}{rr}452 & 547 \\ 55 & 69 \\ 110 & 102 \\ 33 & 40 \\ 21 & 21 \\ 24 & 26 \\ 43 & 40 \\ 30 & 31 \\ 41 & 67 \\ 6 & 5 \\ 59 & 44 \\ 234 & 438 \\ 411 & 404 \\ 270 & 258 \\ 29 & 32 \\ 81 & 146 \\ 259 & 246\end{array}$

$\begin{array}{rr}376 & 437 \\ 59 & 61 \\ 90 & 123 \\ 35 & 35 \\ 22 & 24 \\ 33 & 28 \\ 43 & 42 \\ 35 & 33 \\ 60 & 107 \\ 9 & 1 \\ 51 & 63 \\ 214 & 347 \\ 490 & 250 \\ 254 & 284 \\ 32 & 27 \\ 79 & 87 \\ 264 & 214\end{array}$

$\begin{array}{rr}437 & 531 \\ 61 & 57 \\ 123 & 130 \\ 35 & 42 \\ 24 & 20 \\ 28 & 38 \\ 42 & 44 \\ 33 & 36 \\ 107 & 93 \\ 1 & 8 \\ 63 & 67 \\ 347 & 264 \\ 250 & 311 \\ 284 & 253 \\ 27 & 31 \\ 87 & 69 \\ 214 & 254\end{array}$

$\begin{array}{rrrrr}531 & 353 & 375 & 434 & 396 \\ 57 & 44 & 77 & 71 & 78 \\ 130 & 101 & 170 & 105 & 92 \\ 42 & 42 & 41 & 48 & 36 \\ 20 & 22 & 22 & 23 & 22 \\ 38 & 14 & 33 & 31 & 36 \\ 44 & 40 & 41 & 44 & 44 \\ 36 & 22 & 45 & 30 & 45 \\ 93 & 65 & 41 & 58 & 59 \\ 8 & 7 & 6 & 3 & 10 \\ 67 & 38 & 36 & 42 & 46 \\ 264 & 257 & 229 & 265 & 285 \\ 311 & 526 & 568 & 567 & 528 \\ 253 & 239 & 293 & 276 & 243 \\ 31 & 31 & 29 & 37 & 33 \\ 69 & 85 & 77 & 64 & 83 \\ 254 & 251 & 261 & 278 & 268\end{array}$

Trace elements by INAA

$\begin{array}{lc}\text { (ppm) } & \\ \mathrm{Cs} & 0.35 \\ \mathrm{Hf} & 5.48 \\ \mathrm{Sc} & 21.1 \\ \mathrm{Ta} & 2.73 \\ \mathrm{Th} & 2.56 \\ \mathrm{U} & 0.95\end{array}$

$\begin{array}{cc}0.28 & - \\ 4.80 & - \\ 20.7 & - \\ 2.37 & - \\ 2.54 & - \\ 0.77 & -\end{array}$

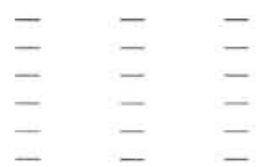

$\begin{array}{cc}0.32 & - \\ 5.75 & - \\ 20.0 & - \\ 2.79 & - \\ 2.65 & - \\ 0.80 & -\end{array}$

$\begin{array}{cc}0.50 & 0.52 \\ 6.20 & 5.27 \\ 23.8 & 18.1 \\ 2.81 & 2.80 \\ 2.80 & 2.62 \\ 0.95 & 0.55\end{array}$

$\begin{array}{cc}0.74 & - \\ 5.80 & - \\ 23.7 & - \\ 2.80 & - \\ 2.80 & - \\ 2.30 & -\end{array}$

$\begin{array}{llc}- & - & 0.33 \\ - & - & 5.88 \\ - & - & 20.9 \\ - & - & 2.79 \\ - & - & 2.76 \\ - & - & 0.97\end{array}$

Rare earth elements (ppm)

$\begin{array}{lcrl}\mathrm{La} & 27.10 & 27.56 & - \\ \mathrm{Ce} & 57.80 & 55.87 & - \\ \mathrm{Pr} & - & 6.31 & - \\ \mathrm{Nd} & 28.00 & 27.17 & - \\ \mathrm{Sm} & 6.65 & 5.68 & - \\ \mathrm{Eu} & 2.11 & 1.89 & - \\ \mathrm{Gd} & - & 5.57 & - \\ \mathrm{Tb} & 0.90 & - & - \\ \mathrm{Dy} & - & 4.91 & - \\ \mathrm{Ho} & - & 0.85 & - \\ \mathrm{Er} & - & 2.36 & - \\ \mathrm{Yb} & 21.12 & 1.97 & - \\ \mathrm{Lu} & 0.296 & 0.32 & -\end{array}$

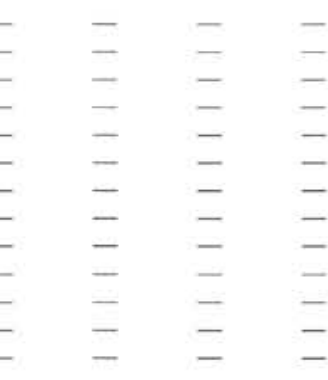

$\begin{array}{ll}27.90 & - \\ 59.40 & - \\ - & - \\ 24.00 & - \\ 6.72 & - \\ 2.16 & - \\ - & - \\ 0.95 & - \\ - & - \\ - & - \\ - & - \\ 2.33 & - \\ 0.336 & -\end{array}$

$\begin{array}{rcrlll}32.84 & 27.00 & 31.84 & - & - & - \\ 67.53 & 56.60 & 66.47 & - & - & - \\ 7.88 & - & 7.68 & - & - & - \\ 32.94 & 25.00 & 32.40 & - & - & - \\ 7.02 & 6.18 & 6.97 & - & - & - \\ 2.37 & 2.06 & 2.31 & - & - & - \\ 7.15 & - & 6.96 & - & - & - \\ - & 0.882 & - & - & - & - \\ 6.25 & - & 6.14 & - & - & - \\ 1.12 & - & 1.08 & - & - & - \\ 3.03 & - & 2.99 & - & - & - \\ 2.56 & 2.02 & 2.52 & - & - & - \\ 0.40 & 0.272 & 0.40 & - & - & -\end{array}$

28.90 60.60

33.00

7.09

2.33

1.09

$-$

following petrogenetic development for the Site 801 tholeiites. The composition of Sample 129-801C-5R-5, 65-69 cm (Table 4), selected from the least altered of the primitive group, is taken to approximate the parental melt composition of the tholeiites: $\mathrm{Mg} * 65, \mathrm{MgO} 7.29 \mathrm{wt} \%, \mathrm{TiO}_{2}$ 0.96 wt\%, Zr 56 ppm, Y 22 ppm, Cr 523 ppm, and Ni 290 ppm. The earliest basalts are evolved group IV (Fig. 9) and can be developed directly by approximately $45 \%$ fractionation of $20 \%$ olivine, $25 \%$ spinel, $45 \%$ plagioclase and $10 \%$ clinopyroxene from the preceding parental composition. An estimate of the relative proportions of parental melt to be mixed with any residual melt in the magma chamber can be obtained using the changes in incompatible element abundances (such as $\mathrm{Zr}$ ) from one chemical group to the next with time. Group IV lavas were terminated by an influx of parental melt that mixed with the remaining fractionated melt ( 1.7 parts residual melt +1 part parental melt) in the magma chamber, which became marginally more primitive in composition (causing $\mathrm{Zr}$ content to decrease from about $160 \mathrm{ppm}$ to about 
Table 4. Chemical analyses of basaltic rocks from Hole 801C.

\begin{tabular}{|c|c|c|c|c|c|c|c|c|c|c|c|c|c|c|}
\hline Core, section: & IR-1 & IR-I & IR-2 & IR-3 & IR-3 & IR-4 & 1R-5 & IR-5 & $2 \mathrm{R}-1$ & $2 \mathrm{R}-1$ & $2 \mathrm{R}-2$ & $2 R-3$ & $2 R-3$ & $2 R-4$ \\
\hline Interval (cm): & $14-20$ & $109-114$ & $11-17$ & $72-76$ & $103-106$ & $0-5$ & $33-38$ & $113-118$ & $1-6$ & $112-118$ & $131-137$ & $105-110$ & $114-119$ & $71-76$ \\
\hline Depth (mbsf): & 493.84 & 494.79 & 495.06 & 497.03 & 497.34 & 497.40 & 498.88 & 499.68 & 503.01 & 504.12 & 505.69 & 506.89 & 506.98 & 507.81 \\
\hline Cooling unit: & $\mathrm{Cl}$ & $\mathrm{Cl}$ & $\mathrm{Cl}$ & $\mathrm{Cl}$ & $\mathrm{C} 2$ & $\mathrm{C} 2$ & $\mathrm{C} 2$ & $\mathrm{C} 2$ & C3 & $\mathrm{C} 3$ & C3 & C4 & C6 & C6 \\
\hline \multicolumn{15}{|c|}{ Major oxides (wt $\%$ ) } \\
\hline $\mathrm{SiO}_{2}$ & 44.06 & 44.92 & 45.17 & 43.37 & 47.70 & 47.20 & 46.13 & 46.20 & 51.99 & 45.53 & 46.22 & 47.61 & 45.25 & 45.95 \\
\hline $\mathrm{TiO}_{2}$ & 2.69 & 2.80 & 2.81 & 3.00 & 3.24 & 3.19 & 3.14 & 2.93 & 3.34 & 3.07 & 2.96 & 3.26 & 3.17 & 3.15 \\
\hline $\mathrm{Al}_{2} \mathrm{O}_{3}$ & 14.18 & 14.72 & 14.87 & 15.99 & 17.11 & 16.95 & 16.57 & 16.72 & 17.94 & 16.31 & 16.42 & 17.49 & 16.77 & 16.40 \\
\hline $\mathrm{Fe}_{2} \mathrm{O}_{3}$ & 4.49 & 3.62 & 4.10 & 4.50 & 3.76 & 3.57 & 3.96 & 3.38 & 3.63 & 4.25 & 4.14 & 3.62 & 3.73 & 3.66 \\
\hline $\mathrm{FeO}$ & 6.34 & 6.40 & 6.30 & 6.60 & 4.48 & 4.52 & 5.79 & 5.71 & 3.01 & 5.32 & 5.74 & 4.65 & 5.27 & 6.19 \\
\hline $\mathrm{MnO}$ & 0.16 & 0.15 & 0.15 & 0.29 & 0.19 & 0.28 & 0.16 & 0.16 & 0.13 & 0.16 & 0.17 & 0.18 & 0.19 & 0.15 \\
\hline $\mathrm{MgO}$ & 10.14 & 9.58 & 9.34 & 6.54 & 4.22 & 2.77 & 5.08 & 5.15 & 2.62 & 4.68 & 6.23 & 3.86 & 4.90 & 5.28 \\
\hline $\mathrm{CaO}$ & 7.44 & 6.46 & 6.34 & 6.53 & 5.00 & 5.73 & 6.59 & 6.15 & 2.35 & 7.14 & 7.06 & 6.01 & 6.34 & 7.13 \\
\hline $\mathrm{Na}_{2} \mathrm{O}$ & 2.58 & 3.45 & 3.63 & 3.14 & 3.56 & 3.41 & 4.63 & 4.74 & 2.53 & 3.94 & 3.53 & 4.01 & 3.98 & 3.86 \\
\hline $\mathrm{K}_{2} \mathrm{O}$ & 1.57 & 1.75 & 1.82 & 2.36 & 4.22 & 4.47 & 2.43 & 2.25 & 6.40 & 2.14 & 2.05 & 2.56 & 2.45 & 2.33 \\
\hline $\mathrm{P}_{2} \mathrm{O}_{5}$ & 0.51 & 0.60 & 0.53 & 0.57 & 0.58 & 0.59 & 0.57 & 0.61 & 0.60 & 0.61 & 0.52 & 0.58 & 0.60 & 0.54 \\
\hline LOI & 5.31 & 5.30 & 5.01 & 6.89 & 5.45 & 6.94 & 4.36 & 5.75 & 4.76 & 6.92 & 5.16 & 6.04 & 7.39 & 5.82 \\
\hline Total & 99.45 & 99.75 & 100.09 & 99.71 & 99.51 & 99.61 & 99.40 & 99.74 & 99.29 & 100.08 & 100.20 & 99.87 & 100.05 & 100.46 \\
\hline $\mathrm{H}_{2} \mathrm{O}+$ & 2.42 & 3.77 & 3.44 & 3.44 & 2.20 & 2.10 & 2.90 & 2.78 & 2.92 & 1.86 & 1.79 & 1.80 & 2.13 & 1.36 \\
\hline $\mathrm{CO}_{2}$ & 2.64 & 1.15 & 1.37 & 3.12 & 3.44 & 4.42 & 1.48 & 2.34 & 1.72 & 4.53 & 3.04 & 3.71 & 4.68 & 4.23 \\
\hline \multicolumn{15}{|c|}{ Trace elements by XRF (ppm) } \\
\hline $\mathrm{Ba}$ & 315 & 427 & 493 & 385 & 689 & 489 & 948 & 633 & 500 & 396 & 355 & 398 & 408 & 387 \\
\hline $\mathrm{Ce}$ & 62 & 55 & 55 & 56 & 64 & 72 & 71 & 70 & 63 & 47 & 55 & 57 & 45 & 67 \\
\hline $\mathrm{Cr}$ & 227 & 154 & 160 & 173 & 99 & 92 & 84 & 78 & 131 & 87 & 170 & 226 & 131 & 76 \\
\hline $\mathrm{Cu}$ & 39 & 40 & 40 & 42 & 34 & 49 & 36 & 36 & 37 & 40 & 36 & 42 & 42 & 40 \\
\hline Ga & 20 & 19 & 19 & 21 & 24 & 25 & 20 & 24 & 20 & 24 & 21 & 24 & 24 & 23 \\
\hline $\mathrm{La}$ & 25 & 24 & 29 & 19 & 19 & 32 & 39 & 27 & 31 & 25 & 27 & 28 & 29 & 26 \\
\hline $\mathrm{Nb}$ & 38 & 41 & 42 & 45 & 45 & 45 & 44 & 41 & 45 & 42 & 39 & 43 & 41 & 41 \\
\hline Nd & 27 & 26 & 28 & 23 & 26 & 41 & 41 & 31 & 33 & 21 & 33 & 33 & 29 & 28 \\
\hline $\mathrm{Ni}$ & 247 & 197 & 212 & 133 & 59 & 74 & 57 & 57 & 119 & 42 & 109 & 116 & 114 & 46 \\
\hline $\mathrm{Pb}$ & 1 & 1 & 3 & 5 & 2 & 3 & 5 & 1 & 2 & 3 & 2 & 1 & 1 & 2 \\
\hline $\mathrm{Rb}$ & 35 & 40 & 41 & 46 & 61 & 62 & 47 & 47 & 66 & 44 & 41 & 50 & 48 & 46 \\
\hline S & 381 & 263 & 261 & 386 & 170 & 222 & 312 & 351 & 231 & 307 & 262 & 341 & 279 & 246 \\
\hline $\mathrm{Sr}$ & 465 & 363 & 360 & 368 & 378 & 349 & 470 & 358 & 160 & 477 & 499 & 507 & 498 & 495 \\
\hline V & 224 & 241 & 205 & 290 & 249 & 264 & 248 & 249 & 279 & 254 & 256 & 267 & 265 & 262 \\
\hline $\mathrm{Y}$ & 27 & 27 & 28 & 31 & 32 & 32 & 32 & 29 & 35 & 31 & 30 & 32 & 30 & 32 \\
\hline $\mathrm{Zn}$ & 84 & 86 & 85 & 119 & 68 & 88 & 76 & 86 & 54 & 83 & 87 & 74 & 78 & 87 \\
\hline $\mathrm{Zr}$ & 221 & 242 & 239 & 262 & 244 & 279 & 267 & 261 & 258 & 259 & 250 & 270 & 255 & 257 \\
\hline \multicolumn{15}{|c|}{ Trace elements by INAA (ppm) } \\
\hline Cs & 0.31 & 0.31 & - & - & - & - & 0.30 & - & - & 0.44 & - & - & 0.42 & 0.40 \\
\hline Hf & 4.90 & 5.40 & - & - & - & - & 5.91 & - & - & 5.70 & - & - & 5.74 & 5.70 \\
\hline Sc & 20.6 & 20.1 & - & - & - & - & 20.6 & - & - & 21.5 & - & - & 19.7 & 20.9 \\
\hline $\mathrm{Ta}$ & 2.31 & 2.62 & - & - & - & - & 2.86 & - & - & 2.46 & - & - & 2.64 & 2.45 \\
\hline Th & 2.50 & 2.61 & - & - & - & - & 2.69 & - & - & 2.43 & - & - & 2.47 & 2.46 \\
\hline $\mathrm{U}$ & 0.83 & 0.97 & - & - & - & - & 1.06 & - & - & 0.81 & - & - & 1.41 & 0.85 \\
\hline \multicolumn{15}{|c|}{ Rare earth elements (ppm) } \\
\hline $\mathrm{La}$ & 28.97 & 27.40 & - & - & - & - & 28.90 & - & - & 31.16 & - & - & 27.70 & 31.14 \\
\hline $\mathrm{Ce}$ & 59.22 & 57.50 & - & - & - & - & 60.30 & - & - & 64.62 & - & - & 58.00 & 64.75 \\
\hline $\operatorname{Pr}$ & 6.69 & - & - & - & - & - & - & - & - & 7.49 & - & - & - & 7.45 \\
\hline $\mathrm{Nd}$ & 28.43 & 30.00 & - & - & - & - & 31.00 & - & - & 31.68 & - & - & 25.00 & 31.41 \\
\hline $\mathrm{Sm}$ & 6.06 & 6.37 & - & - & - & - & 7.02 & - & - & 6.93 & - & - & 6.73 & 6.85 \\
\hline $\mathrm{Eu}$ & 1.99 & 2.05 & - & - & - & - & 2.30 & - & - & 2.32 & - & - & 2.21 & 2.29 \\
\hline Gd & 5.95 & - & - & - & - & - & - & - & - & 6.90 & - & - & - & 6.88 \\
\hline $\mathrm{Tb}$ & - & 0.90 & - & - & - & - & 1.03 & - & - & - & - & - & 0.93 & - \\
\hline Dy & 5.18 & - & - & - & - & - & - & - & - & 6.21 & - & - & - & 6.16 \\
\hline Ho & 0.90 & - & - & - & - & - & - & - & - & 1.09 & - & - & - & 1.09 \\
\hline $\mathrm{Er}$ & 2.50 & - & - & - & - & - & - & - & - & 2.99 & - & - & - & 3.00 \\
\hline $\mathrm{Yb}$ & 2.08 & 2.05 & - & - & - & - & 2.51 & - & - & 2.58 & - & - & 2.25 & 2.56 \\
\hline $\mathrm{Lu}$ & 0.34 & 0.299 & - & - & - & - & 0.36 & - & - & 0.42 & - & - & 0.323 & 0.41 \\
\hline
\end{tabular}

Note: $\mathrm{LOI}=$ loss on ignition $\left(\right.$ at $1200^{\circ} \mathrm{C}$ ).

$120 \mathrm{ppm}$ ). This mixture underwent mild fractionation and erupted as group III lavas. A second influx of parental melt and residual melt mixing ( 0.8 parts residual melt +1 part parental melt) produced an overall more primitive composition (causing $\mathrm{Zr}$ contents to decrease from about $140 \mathrm{ppm}$ to about $95 \mathrm{ppm}$ ) that first erupted group II lavas and then via progressive fractionation produced group I lavas. After this stage only the primitive group lavas were erupted, with the parental melt derived from, either (1) a separate fractionating magma chamber (the evolved group magma chamber having now been evacuated), or (2) the same magma chamber wherein any remaining melt was totally swamped $(0.07$ parts residual melt +1 part parental melt) by the parental composition. After each influx of parental melt and mixing, the remaining melt underwent mild fractionation such that within each chemical group the lavas became more evolved with time; these processes are diagrammatically illustrated in Figure 13. Some of the very high-Mg* lavas could have been derived directly 
Table 4 (continued).

\begin{tabular}{|c|c|c|c|c|c|c|c|c|c|c|c|c|c|c|}
\hline Core, section: & 2R-5 & $3 R-1$ & $5 R-1$ & $5 R-2$ & $5 R-2$ & $5 R-2$ & $5 R-3$ & SR-3 & $5 R-3$ & $5 R-3$ & $5 R-3$ & $5 R-4$ & $5 R-5$ & $5 R-5$ \\
\hline Interval (cm): & $101-106$ & $42-48$ & $45-52$ & $12-17$ & $87-89$ & $123-130$ & $38-43$ & $43-45$ & $99-104$ & $103-105$ & $125-131$ & $65-70$ & $65-69$ & $73-78$ \\
\hline Depth (mbsf): & 509.50 & 512.63 & 531.65 & 532.58 & 533.69 & 533.69 & 534.15 & 534.20 & 534.76 & 534.80 & 535.02 & 535.92 & 537.34 & 537.42 \\
\hline Cooling unit: & C6 & $\mathrm{C7}$ & $\mathrm{CP}$ & $\mathrm{C} 9$ & $\mathrm{C} 9$ & $\mathrm{C} 9$ & $\mathrm{C} 9$ & $\mathrm{C} 9$ & $\mathrm{C} 10$ & $\mathrm{C} 10$ & $\mathrm{C} 11$ & $\mathrm{C} 13$ & $\mathrm{Cl} 3$ & $\mathrm{Cl} 3$ \\
\hline \multicolumn{15}{|c|}{ Major oxides (wt\%) } \\
\hline $\mathrm{SiO}_{2}$ & 46.00 & 52.83 & 42.69 & 48.10 & 45.35 & 50.75 & 45.91 & 46.99 & 51.59 & 52.13 & 45.59 & 47.42 & 48.13 & 47.07 \\
\hline $\mathrm{TiO}_{2}^{2}$ & 3.13 & 3.53 & 1.17 & 1.02 & 1.20 & 1.03 & 1.15 & 1.14 & 1.16 & 1.23 & 1.03 & 0.97 & 0.96 & 0.93 \\
\hline $\mathrm{Al}_{2} \mathrm{O}_{3}$ & 16.81 & 18.77 & 20.43 & 15.75 & 19.62 & 17.89 & 19.39 & 19.67 & 19.76 & 18.78 & 6.63 & 16.46 & 16.61 & 16.51 \\
\hline $\mathrm{Fe}_{2} \mathrm{O}_{3}$ & 3.99 & 5.09 & 2.27 & 6.49 & 3.85 & 4.91 & 3.46 & 2.74 & 1.97 & 4.76 & 6.62 & 2.37 & 4.47 & 3.36 \\
\hline $\mathrm{FeO}$ & 6.08 & 1.00 & 1.05 & 1.29 & 1.96 & 2.44 & 3.60 & 4.38 & 1.90 & 0.61 & 9.58 & 6.31 & 4.60 & 5.72 \\
\hline $\mathrm{MnO}$ & 0.16 & 0.05 & 0.10 & 0.18 & 0.10 & 0.09 & 0.13 & 0.14 & 0.11 & 0.07 & 0.39 & 0.14 & 0.14 & 0.17 \\
\hline $\mathrm{MgO}$ & 6.16 & 3.32 & 3.31 & 3.45 & 3.06 & 2.72 & 4.79 & 4.92 & 1.58 & 1.86 & 4.05 & 8.58 & 7.29 & 7.17 \\
\hline $\mathrm{CaO}$ & 6.78 & 1.94 & 15.86 & 9.31 & 13.57 & 9.38 & 13.14 & 13.08 & 11.48 & 5.02 & 6.94 & 12.08 & 12.83 & 12.88 \\
\hline $\mathrm{Na}_{2} \mathrm{O}$ & 3.67 & 2.28 & 3.09 & 1.99 & 2.93 & 2.60 & 2.74 & 2.75 & 2.81 & 1.37 & 1.28 & 2.24 & 2.34 & 2.17 \\
\hline $\mathrm{K}_{2} \mathrm{O}$ & 2.20 & 5.68 & 0.89 & 4.39 & 0.70 & 1.88 & 0.06 & 0.08 & 1.73 & 6.88 & 1.28 & 0.08 & 0.09 & 0.05 \\
\hline $\mathrm{P}_{2} \mathrm{O}_{5}$ & 0.53 & 0.62 & 0.02 & 0.01 & 0.02 & 0.01 & 0.07 & 0.01 & 0.02 & 0.02 & 0.05 & 0.01 & 0.13 & 0.01 \\
\hline LOI & 4.62 & 4.58 & 9.14 & 8.43 & 7.27 & 6.08 & 5.06 & 4.22 & 5.76 & 6.74 & 15.92 & 3.18 & 2.79 & 3.93 \\
\hline Total & 100.13 & 99.69 & 100.03 & 100.42 & 99.64 & 99.78 & 99.50 & 100.10 & 99.88 & 99.66 & 99.35 & 99.82 & 100.38 & 99.94 \\
\hline $\mathrm{H}_{2} \mathrm{O}+$ & 1.77 & 4.00 & 2.02 & 2.53 & 2.36 & 1.65 & 1.44 & 1.50 & 1.19 & 5.77 & 1.49 & 0.81 & - & 1.09 \\
\hline $\mathrm{CO}_{2}$ & 2.70 & 0.41 & 6.45 & 5.17 & 5.10 & 3.90 & 3.12 & 3.08 & 4.08 & 1.02 & 14.49 & 2.14 & - & 2.59 \\
\hline \multicolumn{15}{|c|}{ Trace elements by XRF (ppm) } \\
\hline $\mathrm{Ba}$ & 412 & 424 & 22 & 47 & 14 & 29 & I5 & 8 & 16 & 149 & 16 & 15 & 16 & 16 \\
\hline $\mathrm{Ce}$ & 64 & 61 & 8 & 6 & 12 & 7 & 6 & 4 & 6 & 10 & 6 & 5 & 7 & 5 \\
\hline $\mathrm{Cr}$ & 84 & 155 & 334 & 288 & 342 & 318 & 335 & 347 & 338 & 341 & 65 & 464 & 523 & 570 \\
\hline $\mathrm{Cu}$ & 44 & 55 & 81 & 87 & 88 & 38 & 86 & 87 & 88 & 20 & 47 & 81 & 75 & 81 \\
\hline $\mathrm{Ga}$ & 22 & 24 & 17 & 13 & 18 & 12 & 18 & 17 & 19 & 12 & 11 & 12 & 14 & 15 \\
\hline $\mathrm{La}$ & 26 & 18 & 2 & 3 & 3 & 1 & 3 & 1 & 2 & 2 & 1 & 1 & 2 & 1 \\
\hline $\mathrm{Nb}$ & 40 & 46 & 2 & 4 & 2 & 2 & 3 & 3 & 2 & 2 & 4 & 2 & 4 & 2 \\
\hline $\mathrm{Nd}$ & 33 & 23 & 10 & 8 & 15 & 7 & 8 & 4 & 7 & 12 & 9 & 6 & 8 & 6 \\
\hline $\mathrm{Ni}$ & 56 & 99 & 96 & 73 & 85 & 69 & 89 & 103 & 77 & 46 & 120 & 217 & 290 & 375 \\
\hline $\mathrm{Pb}$ & 1 & 1 & 1 & 2 & 1 & 1 & 1 & 1 & 2 & I & 5 & 1 & 2 & 1 \\
\hline $\mathrm{Rb}$ & 42 & 71 & 13 & 77 & 18 & 34 & 3 & 3 & 14 & 59 & 32 & 3 & 5 & 2 \\
\hline S & 247 & 120 & 574 & 163 & 326 & 127 & 493 & 467 & 265 & 125 & 168 & 390 & 387 & 797 \\
\hline $\mathrm{Sr}$ & 499 & 112 & 160 & 123 & 155 & 155 & 143 & 146 & 143 & 82 & 89 & 113 & 155 & 116 \\
\hline V & 241 & 284 & 276 & 145 & 245 & 191 & 233 & 247 & 235 & 183 & 387 & 199 & 208 & 198 \\
\hline $\mathrm{Y}$ & 31 & 32 & 27 & 19 & 21 & 12 & 24 & 23 & 25 & 25 & 49 & 26 & 22 & 23 \\
\hline $\mathrm{Zn}$ & 78 & 85 & 52 & 64 & 48 & 51 & 56 & 57 & 37 & 39 & 181 & 62 & 64 & 65 \\
\hline $\mathrm{Zr}$ & 255 & 248 & 74 & 64 & 66 & 56 & 69 & 69 & 69 & 70 & 67 & 56 & 56 & 55 \\
\hline \multicolumn{15}{|c|}{ Trace elements by INAA (ppm) } \\
\hline Cs & - & - & 0.20 & - & 0.19 & 一 & 0.12 & - & - & 0.46 & 0.27 & - & - & - \\
\hline Hf & - & - & 2.00 & - & 1.78 & 一 & 1.67 & - & - & 1.72 & 1.33 & - & - & - \\
\hline $\mathrm{Sc}$ & - & - & 40.2 & - & 38.8 & - & 37.7 & - & - & 29.7 & 53.1 & - & - & - \\
\hline $\mathrm{Ta}$ & - & - & 0.049 & - & 0.06 & - & 0.07 & - & - & 0.05 & 0.091 & - & - & - \\
\hline Th & - & - & - & - & 0.08 & - & 0.13 & - & - & 0.10 & 0.11 & - & - & - \\
\hline $\mathrm{U}$ & - & - & - & - & 0.20 & - & 0.19 & - & - & 0.47 & 0.81 & - & - & - \\
\hline \multicolumn{15}{|c|}{ Rare earth elements (ppm) } \\
\hline $\mathrm{La}$ & - & - & 1.73 & - & 1.45 & - & 1.37 & - & - & 1.86 & 3.95 & - & - & - \\
\hline $\mathrm{Ce}$ & - & - & 6.80 & - & 5.40 & - & 5.30 & - & - & 6.00 & 10.44 & - & - & - \\
\hline $\operatorname{Pr}$ & - & - & - & - & - & - & - & - & - & - & 1.78 & - & - & - \\
\hline $\mathrm{Nd}$ & - & - & 8.00 & - & 6.00 & - & 6.00 & - & - & 9.00 & 11.10 & - & - & - \\
\hline $\mathrm{Sm}$ & - & - & 2.52 & - & 2.25 & - & 2.29 & - & - & 2.39 & 3.46 & - & - & - \\
\hline Eu & - & - & 1.02 & - & 0.90 & - & 0.94 & - & - & 0.926 & 1.25 & - & - & - \\
\hline $\mathrm{Gd}$ & - & - & - & - & - & - & - & - & - & - & 5.73 & - & - & - \\
\hline $\mathrm{Tb}$ & - & - & 0.62 & - & 0.51 & - & 0.61 & - & - & 0.57 & - & - & - & - \\
\hline Dy & - & - & - & - & - & - & - & - & - & - & 7.62 & - & - & - \\
\hline Но & - & - & - & - & - & - & - & - & - & - & 1.56 & - & - & - \\
\hline $\mathrm{Er}$ & - & - & - & - & - & - & - & - & - & - & 4.74 & - & - & - \\
\hline $\mathrm{Yb}$ & - & - & 2.24 & - & 1.93 & - & 2.12 & - & - & 1.78 & 4.74 & - & - & - \\
\hline Lu & - & - & 0.332 & - & 0.27 & - & 0.332 & - & - & 0.247 & 0.81 & - & - & - \\
\hline
\end{tabular}

from the mantle, and although they appear parental to the rest of the primitive group that evolved with time, a magma chamber is still implied within which fractionation took place.

Downhole chemical cyclicity exemplified by different groups or packets of lavas is a characteristic feature of many sections of oceanic crust (e.g., Thompson et al., 1976; Flower et al., 1980; Saunders, 1983) and has been attributed to (1) open-system, differential melt mixing within large magma chambers (Rhodes et al., 1979; Natland et al., 1983) and (2) successive batches of different partial melts derived from separate, small or short-lived, magma chambers (Blanchard et al., 1976; Flower et al., 1977; Wood et al., 1979). As there is no evidence for separate melt batches produced by variable degrees of partial melting within the Site 801 tholeiitic basalts, we considered that the mixing model best describes the chemical variation displayed.

\section{Upper Alkalic Basalts}

As indicated previously, the alkalic basalts are systematically enriched in incompatible elements relative to the N-MORB of the tholeiitic sequence. They are characterized by (1) specific incompat- 
Table 4 (continued).

\begin{tabular}{|c|c|c|c|c|c|c|c|c|c|c|c|c|c|c|}
\hline Core, section: & $6 \mathrm{R}-2$ & $6 \mathrm{R}-2$ & $6 R-3$ & $6 \mathrm{R}-3$ & $6 R-4$ & $6 \mathrm{R}-5$ & $7 R-1$ & $7 R-1$ & $7 \mathrm{R}-1$ & 7R-2 & 7R-3 & $7 R-3$ & $7 R-3$ & $7 R-4$ \\
\hline Interval $(\mathrm{cm})$ : & $29-34$ & $119-124$ & $37-42$ & $75-80$ & $49-54$ & $52-57$ & $21-26$ & $53-58$ & $99-105$ & $122-127$ & $0-5$ & $103-110$ & $138-140$ & $77-83$ \\
\hline Depth (mbsf): & 542,08 & 542.98 & 543.56 & 543.94 & 545.14 & 546.55 & 550.31 & 550.63 & 551.09 & 552.77 & 552.98 & 554.01 & 554.36 & 555.20 \\
\hline Cooling unit: & $\mathrm{C} 16$ & $\mathrm{C} 16$ & $\mathrm{C} 20$ & $\mathrm{C} 20$ & $\mathrm{C} 20$ & $\mathrm{C} 21$ & $\mathrm{C} 21$ & $\mathrm{C} 21$ & $\mathrm{C} 21$ & $\mathrm{C} 22$ & $\mathrm{C} 23$ & $\mathrm{C} 23$ & $\mathrm{C} 23$ & $\mathrm{C} 23$ \\
\hline \multicolumn{15}{|c|}{ Major oxides (wt\%) } \\
\hline $\mathrm{SiO}_{2}$ & 46.43 & 46.40 & 40.58 & 47.27 & 46.63 & 47.32 & 48.58 & 48.26 & 47.01 & 48.49 & 47.04 & 48.78 & 47.57 & 48.88 \\
\hline $\mathrm{TiO}_{2}$ & 0.98 & 1.00 & 0.98 & 0.97 & 0.89 & 1.85 & 1.87 & 1.93 & 1.96 & 1.85 & 1.97 & 2.03 & 1.93 & 2.01 \\
\hline $\mathrm{Al}_{2} \mathrm{O}_{3}$ & 16.32 & 17.22 & 17.53 & 17.10 & 16.44 & 13.59 & 13.43 & 13.23 & 13.58 & 13.60 & 13.82 & 14.59 & 14.10 & 13.71 \\
\hline $\mathrm{Fe}_{2} \mathrm{O}_{3}$ & 2.54 & 3.44 & 2.87 & 3.04 & 2.19 & 2.78 & 3.47 & 3.50 & 3.35 & 3.15 & 6.40 & 4.72 & 4.68 & 4.17 \\
\hline $\mathrm{FeO}$ & 5.90 & 4.85 & 2.48 & 5.65 & 6.32 & 8.77 & 9.15 & 9.12 & 8.43 & 8.27 & 6.46 & 6.29 & 7.18 & 7.65 \\
\hline $\mathrm{MnO}$ & 0.14 & 0.16 & 0.18 & 0.14 & 0.14 & 0.19 & 0.20 & 0.20 & 0.19 & 0.21 & 0.15 & 0.14 & 0.17 & 0.17 \\
\hline $\mathrm{MgO}$ & 9.67 & 7.69 & 2.71 & 7.86 & 10.14 & 6.65 & 6.84 & 6.96 & 6.62 & 6.75 & 6.18 & 6.86 & 6.79 & 6.64 \\
\hline $\mathrm{CaO}$ & 11.48 & 12.84 & 16.37 & 12.54 & 12.29 & 11.66 & 11.57 & 11.16 & 11.44 & 11.94 & 11.16 & 11.03 & 11.72 & 11.31 \\
\hline $\mathrm{Na}_{2} \mathrm{O}$ & 2.16 & 2.37 & 2.63 & 2.34 & 2.03 & 2.71 & 2.68 & 2.68 & 2.73 & 2.71 & 2.79 & 2.95 & 2.87 & 2.76 \\
\hline $\mathrm{K}_{2} \mathrm{O}$ & 0.05 & 0.02 & 0.90 & 0.02 & 0.04 & 0.10 & 0.07 & 0.08 & 0.06 & 0.11 & 0.44 & 0.05 & 0.05 & 0.07 \\
\hline $\mathrm{P}_{2} \mathrm{O}_{5}$ & 0.05 & 0.01 & 0.01 & 0.06 & 0.10 & 0.08 & 0.08 & 0.16 & 0.15 & 0.08 & 0.10 & 0.16 & 0.09 & 0.09 \\
\hline LOI & 4.45 & 3.91 & 12.28 & 3.32 & 2.87 & 3.60 & 2.35 & 2.58 & 3.86 & 1.92 & 2.95 & 2.04 & 2.12 & 1.70 \\
\hline Total & 100.18 & 99.90 & 99.51 & 100.31 & 99.97 & 99.19 & 100.29 & 99.86 & 99.38 & 99.08 & 99.47 & 99.00 & 99.28 & 99.16 \\
\hline $\mathrm{H}_{2} \mathrm{O}+$ & 1.51 & 1.10 & 1.86 & 1.05 & 0.73 & 0.55 & 0.58 & 0.59 & 0.85 & 0.59 & 1.11 & 0.84 & 0.68 & 0.91 \\
\hline $\mathrm{CO}_{2}$ & 2.58 & 2.61 & 10.03 & 1.67 & 1.92 & 2.77 & 1.49 & 1.31 & 2.52 & 1.18 & 1.90 & 0.76 & 1.37 & 0.64 \\
\hline
\end{tabular}

\begin{tabular}{|c|c|c|c|c|c|c|c|c|c|c|c|c|c|c|}
\hline \multicolumn{15}{|c|}{ Trace elements by XRF (ppm) } \\
\hline $\mathrm{Ba}$ & 8 & 6 & 7 & 14 & 10 & 21 & 23 & 32 & 27 & 25 & 20 & 15 & 15 & 18 \\
\hline $\mathrm{Ce}$ & 4 & 6 & 6 & 8 & 4 & 6 & 12 & 6 & 6 & 10 & 12 & 11 & 10 & 13 \\
\hline $\mathrm{Cr}$ & 559 & 557 & 515 & 402 & 455 & 161 & 148 & 140 & 154 & 147 & 130 & 143 & 144 & 156 \\
\hline $\mathrm{Cu}$ & 79 & 82 & 85 & 88 & 77 & 73 & 74 & 81 & 73 & 77 & 74 & 80 & 76 & 76 \\
\hline Ga & 14 & 14 & 15 & 16 & 14 & 20 & 20 & 19 & 19 & 20 & 22 & 21 & 20 & 20 \\
\hline $\mathrm{La}$ & 2 & 2 & 1 & 2 & 1 & 2 & 2 & 2 & 2 & 3 & 3 & 2 & 2 & 4 \\
\hline $\mathrm{Nb}$ & 2 & 2 & 3 & 2 & 3 & 5 & 5 & 5 & 6 & 5 & 5 & 5 & 5 & 6 \\
\hline $\mathrm{Nd}$ & 6 & 8 & 8 & 11 & 4 & 8 & 13 & 9 & 8 & 12 & 13 & 16 & 12 & 15 \\
\hline $\mathrm{Ni}$ & 240 & 283 & 220 & 183 & 231 & 77 & 71 & 71 & 71 & 60 & 58 & 59 & 62 & 67 \\
\hline $\mathrm{Pb}$ & 1 & 1 & 1 & 2 & 1 & 3 & 6 & 5 & 5 & 3 & 7 & 4 & 6 & 6 \\
\hline $\mathrm{Rb}$ & 4 & 2 & 9 & 1 & 2 & 3 & 1 & 1 & 1 & 3 & 14 & 1 & 1 & 2 \\
\hline S & 383 & 505 & 323 & 399 & 389 & 525 & 534 & 576 & 607 & 520 & 502 & 191 & 394 & 622 \\
\hline $\mathrm{Sr}$ & 100 & 109 & 130 & 103 & 138 & 131 & 118 & 114 & 118 & 123 & 126 & 125 & 124 & 117 \\
\hline V & 217 & 213 & 264 & 211 & 186 & 400 & 405 & 416 & 439 & 408 & 476 & 479 & 437 & 429 \\
\hline $\mathrm{Y}$ & 24 & 26 & 18 & 25 & 22 & 42 & 43 & 44 & 43 & 44 & 41 & 42 & 43 & 44 \\
\hline $\mathrm{Zn}$ & 53 & 69 & 52 & 63 & 56 & 93 & 99 & 98 & 101 & 97 & 107 & 104 & 97 & 106 \\
\hline $\mathrm{Zr}$ & 55 & 60 & 48 & 58 & 52 & 114 & 117 & 119 & 120 & 116 & 119 & 123 & 120 & 120 \\
\hline
\end{tabular}

Trace elements by INAA (ppm)

\begin{tabular}{|c|c|c|c|c|c|c|c|c|c|c|c|c|c|c|}
\hline & & & & & & & & & & & & & & \\
\hline Cs & 0.11 & 0.045 & 0.07 & - & - & - & - & 0.05 & 0.30 & - & 0.26 & - & - & 0.20 \\
\hline $\mathrm{Hf}$ & 1.42 & 1.50 & 1.18 & - & - & - & - & 2.90 & 3.36 & - & 2.90 & - & - & 3.18 \\
\hline $\mathrm{Sc}$ & 39.5 & 40.4 & 26.7 & - & - & - & - & 42.0 & 46.6 & - & 43.4 & - & - & 47.1 \\
\hline $\mathrm{Ta}$ & 0.06 & 0.02 & 0.035 & - & - & - & - & 0.18 & 0.19 & - & 0.18 & - & - & 0.20 \\
\hline Th & 0.08 & 0.025 & 0.03 & - & - & - & - & 0.192 & 0.14 & - & 0.18 & - & - & 0.16 \\
\hline $\mathrm{U}$ & 0.20 & 0.018 & 0.67 & - & - & - & - & 0.10 & 0.40 & - & 0.26 & - & - & 0.40 \\
\hline $\operatorname{Ran}$ & $\mathrm{s}$ (ppm) & & & & & & & & & & & & & \\
\hline $\mathrm{La}$ & 0.99 & 1.51 & 1.83 & - & - & - & - & 5.37 & 3.63 & - & 4.36 & - & - & 3.71 \\
\hline $\mathrm{Ce}$ & 3.90 & 5.23 & 5.19 & - & - & - & - & 15.13 & 11.20 & - & 12.66 & - & - & 11.40 \\
\hline Pr & - & 1.26 & 1.05 & - & - & - & - & 2.36 & - & - & 2.04 & - & - & - \\
\hline $\mathrm{Nd}$ & 5.00 & 7.04 & 5.69 & - & - & - & - & 13.36 & 13.00 & - & 12.27 & - & - & 12.00 \\
\hline $\mathrm{Sm}$ & 1.97 & 1.97 & 1.54 & - & - & - & - & 4.24 & 4.08 & - & 3.85 & - & - & 4.25 \\
\hline Eu & 0.80 & 0.87 & 0.70 & - & - & - & - & 1.49 & 1.48 & - & 1.45 & - & - & 1.51 \\
\hline $\mathrm{Gd}$ & - & 3.37 & 2.46 & - & - & - & - & 6.03 & - & - & 5.65 & - & - & - \\
\hline $\mathrm{Tb}$ & 0.56 & - & - & - & - & - & - & - & 1.03 & - & - & - & - & 1.05 \\
\hline Dy & - & 4.06 & 2.89 & - & - & - & - & 7.48 & - & - & 6.98 & - & - & - \\
\hline Ho & - & 0.82 & 0.58 & - & - & - & - & 1.48 & - & - & 1.39 & - & - & - \\
\hline $\mathrm{Er}$ & - & 2.53 & 1.82 & - & - & - & - & 4.39 & - & - & 4.04 & - & - & - \\
\hline $\mathrm{Yb}$ & 2.29 & 2.44 & 1.72 & - & - & - & - & 4.36 & 4.08 & - & 3.96 & - & - & 4.25 \\
\hline $\mathrm{Lu}$ & 0.35 & 0.44 & 0.30 & - & - & - & - & 0.74 & 0.621 & - & 0.66 & - & - & 0.643 \\
\hline
\end{tabular}

ible element ratios, for example, $\mathrm{Zr} / \mathrm{Nb}$ (about 5.8), $\mathrm{Zr} / \mathrm{Y}$ (about 8.3), $\mathrm{Th} / \mathrm{Hf}$ (about 0.45 ) and P/Ce (about 45), and (2) chondrite-normalized light REE enriched patterns, with $(\mathrm{La} / \mathrm{Yb})_{\mathrm{N}}$ about 10 . Although many LIL elements have characteristically high abundances (mainly reflecting primary amphibole and biotite) their ranges suggest that they have been partly mobilized during secondary alteration (for example, $\mathrm{Sr}$ (100-700 ppm) and $\mathrm{Rb}(30-100 \mathrm{ppm})$ do not entirely reflect magmatic compositions). They are also isotopically distinct from the tholeiites with higher ${ }^{87} \mathrm{Sr} /{ }^{86} \mathrm{Sr}$ and lower ${ }^{143} \mathrm{Nd} /{ }^{144} \mathrm{Nd}$ ratios (Castillo et al., this volume). Overall, the alkalic basalts exhibit chemical features typical of OIB and correspond to the "moderately alkaline" group of oceanic islands defined by Baker (1973). The range of $\mathrm{K}_{2} \mathrm{O}$ contents (1-3 wt\%) and the low $\mathrm{K}_{2} \mathrm{O} / \mathrm{Na}_{2} \mathrm{O}$ ratio $(0.5-0.6)$ in the freshest samples, suggest they belong to the sodic alkaline suite with the primitive group representing olivine basalts, whereas the evolved group are mainly hawaiites with $\mathrm{MgO}<6 \mathrm{wt} \%$ and $\mathrm{Zr}>250 \mathrm{ppm}$ (Hughes and Brown, 1972).

The alkalic basalts show a range of $\mathrm{Mg} *$ (Fig. 10), with the highest values $(60-68)$ representing the olivine-rich primitive group basalts (B6-B7 and C1; Table 2), which can be matched by many differentiated 
Table 4 (continued).

\begin{tabular}{|c|c|c|c|c|c|c|c|c|c|c|c|c|c|c|}
\hline Core, section: & $7 R-4$ & $8 \mathrm{R}-1$ & $8 R-1$ & $8 R-1$ & $8 R-2$ & $8 R-2$ & 8R-2 & $8 \mathrm{R}-2$ & $9 \mathrm{R}-1$ & 9R-2 & $9 \mathrm{R}-3$ & $9 \mathrm{R}-3$ & $9 \mathrm{R}-4$ & $9 R-5$ \\
\hline Interval $(\mathrm{cm})$ : & $137-142$ & $18-21$ & $65-67$ & $101-106$ & $69-74$ & $78-80$ & $95-99$ & $135-139$ & $37-42$ & $63-68$ & $32-38$ & $76-81$ & $58-94$ & $0-7$ \\
\hline Depth (mbsf): & 555.80 & 559.68 & 560.15 & 560.51 & 561.26 & 561.35 & 561.52 & 561.90 & 563.57 & 565.23 & 566.26 & 566.70 & 568.09 & 568.61 \\
\hline Cooling unit: & $\mathrm{C} 23$ & $\mathrm{C} 23$ & C24 & $\mathrm{C} 24$ & $\mathrm{C} 24$ & C24 & $\mathrm{C} 24$ & $\mathrm{C} 24$ & $\mathrm{C} 25$ & $\mathrm{C} 25$ & $\mathrm{C} 25$ & $\mathrm{C} 25$ & $\mathrm{C} 25$ & $\mathrm{C} 25$ \\
\hline \multicolumn{15}{|c|}{ Major oxides (wt\%) } \\
\hline $\mathrm{SiO}_{2}$ & 46.61 & 47.68 & 46.66 & 47.38 & 47.34 & 47.49 & 47.63 & 48.52 & 47.84 & 49.50 & 49.29 & 48.70 & 49.00 & 49.40 \\
\hline $\mathrm{TiO}_{2}$ & 1.91 & 2.32 & 2.19 & 1.90 & 1.90 & 1.89 & 1.94 & 1.91 & 1.80 & 1.63 & 1.64 & 1.67 & 1.62 & 1.63 \\
\hline $\mathrm{Al}_{2} \mathrm{O}_{3}$ & 13.41 & 16.34 & 15.92 & 13.32 & 13.56 & 13.36 & 13.22 & 13.40 & 15.51 & 14.09 & 13.97 & 13.75 & 13.90 & 13.95 \\
\hline $\mathrm{Fe}_{2} \mathrm{O}_{3}$ & 3.06 & 5.18 & 7.86 & 2.76 & 2.94 & 3.48 & 2.67 & 3.59 & 5.45 & 3.73 & 3.87 & 3.70 & 3.75 & 3.92 \\
\hline $\mathrm{FeO}$ & 8.30 & 5.06 & 2.25 & 9.57 & 8.88 & 8.25 & 8.91 & 8.90 & 5.59 & 8.09 & 8.05 & 7.72 & 8.03 & 8.15 \\
\hline $\mathrm{MnO}$ & 0.19 & 0.13 & 0.08 & 0.23 & 0.19 & 0.21 & 0.21 & 0.20 & 0.11 & 0.19 & 0.18 & 0.17 & 0.19 & 0.18 \\
\hline $\mathrm{MgO}$ & 6.25 & 4.55 & 2.99 & 6.61 & 6.59 & 7.40 & 6.51 & 6.66 & 6.52 & 7.28 & 7.34 & 7.29 & 6.92 & 7.44 \\
\hline $\mathrm{CaO}$ & 12.31 & 9.28 & 10.65 & 11.77 & 11.64 & 12.82 & 12.10 & 11.47 & 10.84 & 12.15 & 11.70 & 12.26 & 12.16 & 11.83 \\
\hline $\mathrm{Na}_{2} \mathrm{O}$ & 2.82 & 3.59 & 3.47 & 2.69 & 2.75 & 2.71 & 2.68 & 3.49 & 3.16 & 2.61 & 2.65 & 2.61 & 2.63 & 2.54 \\
\hline $\mathrm{K}_{2} \mathrm{O}$ & 0.10 & 0.27 & 0.84 & 0.10 & 0.06 & 0.08 & 0.10 & 0.09 & 0.10 & 0.05 & 0.07 & 0.04 & 0.04 & 0.05 \\
\hline $\mathrm{P}_{2} \mathrm{O}_{5}$ & 0.09 & 0.12 & 0.14 & 0.09 & 0.08 & 0.16 & 0.15 & 0.15 & 0.08 & 0.05 & 0.06 & 0.12 & 0.06 & 0.06 \\
\hline LOI & 4.41 & 5.48 & 7.30 & 3.61 & 3.88 & 3.34 & 3.35 & 1.77 & 2.46 & 1.05 & 1.08 & 1.62 & 1.13 & 0.99 \\
\hline Total & 99.46 & 99.99 & 100.35 & 100.01 & 99.81 & 100.19 & 99.48 & 100.16 & 99.46 & 100.42 & 99.90 & 99.67 & 99.44 & 100.14 \\
\hline $\mathrm{H}_{2} \mathrm{O}+$ & 0.51 & 1.43 & 5.34 & 0.55 & 0.58 & 1.45 & 0.54 & 0.91 & 1.09 & 0.59 & 0.59 & 0.63 & 0.53 & 0.61 \\
\hline $\mathrm{CO}_{2}$ & 3.67 & 3.85 & 2.10 & 2.72 & 2.88 & 2.77 & 2.38 & 0.64 & 1.52 & 0.23 & 0.24 & 0.60 & 0.55 & 0.16 \\
\hline \multicolumn{15}{|c|}{ Trace elements by XRF (ppm) } \\
\hline $\mathrm{Ba}$ & 27 & 19 & 29 & 13 & 19 & 13 & 20 & 20 & 24 & 14 & 7 & 13 & 17 & 18 \\
\hline $\mathrm{Ce}$ & 7 & 10 & 15 & 9 & 16 & 12 & 10 & 10 & 9 & 10 & 10 & 8 & 6 & 5 \\
\hline $\mathrm{Cr}$ & 122 & 200 & 181 & 128 & 135 & 143 & 126 & 140 & 204 & 186 & 174 & 186 & 171 & 175 \\
\hline $\mathrm{Cu}$ & 71 & 79 & 73 & 73 & 73 & 74 & 72 & 74 & 79 & 77 & 75 & 84 & 76 & 74 \\
\hline $\mathrm{Ga}$ & 22 & 22 & 24 & 18 & 18 & 19 & 17 & 19 & 21 & 20 & 19 & 16 & 19 & 17 \\
\hline $\mathrm{La}$ & 2 & 3 & 3 & 2 & 2 & 3 & 2 & 2 & 2 & 3 & 3 & 2 & 2 & 2 \\
\hline $\mathrm{Nb}$ & 5 & 5 & 4 & 5 & 5 & 5 & 5 & 4 & 4 & 4 & 4 & 4 & 4 & 4 \\
\hline $\mathrm{Nd}$ & 7 & 15 & 18 & 12 & 18 & 15 & 12 & 10 & 12 & 15 & 12 & 12 & 8 & 8 \\
\hline $\mathrm{Ni}$ & 56 & 67 & 61 & 55 & 62 & 58 & 58 & 64 & 69 & 69 & 65 & 68 & 68 & 66 \\
\hline $\mathrm{Pb}$ & 5 & 2 & 2 & 5 & 5 & 6 & 5 & 6 & 6 & 4 & 7 & 6 & 5 & 7 \\
\hline $\mathrm{Rb}$ & 2 & 5 & 20 & 3 & 2 & 2 & 1 & 3 & 2 & 1 & 1 & 1 & 1 & 1 \\
\hline S & 644 & 317 & 269 & 561 & 549 & 541 & 506 & 654 & 395 & 502 & 540 & 592 & 605 & 579 \\
\hline $\mathrm{Sr}$ & 131 & 152 & 150 & 122 & 125 & 124 & 123 & 115 & 133 & 115 & 112 & 113 & 115 & 114 \\
\hline V & 416 & 579 & 528 & 421 & 437 & 388 & 421 & 430 & 438 & 380 & 355 & 365 & 355 & 359 \\
\hline$Y$ & 43 & 38 & 41 & 44 & 43 & 42 & 42 & 44 & 36 & 37 & 38 & 36 & 37 & 37 \\
\hline $\mathrm{Zn}$ & 94 & 144 & 70 & 107 & 104 & 101 & 100 & 104 & 99 & 91 & 86 & 86 & 87 & 84 \\
\hline $\mathrm{Zr}$ & 116 & 135 & 112 & 116 & 116 & 113 & 115 & 116 & 106 & 97 & 96 & 95 & 96 & 97 \\
\hline \multicolumn{15}{|c|}{ Trace elements by INAA (ppm) } \\
\hline Cs & 0.05 & - & 0.31 & 0.10 & - & 0.30 & - & 0.09 & - & - & - & 0.20 & 0.05 & - \\
\hline Hf & 2.70 & - & 3.30 & 2.80 & - & 3.01 & - & 3.17 & - & - & - & 2.58 & 2.30 & - \\
\hline $\mathrm{Sc}$ & 43.9 & - & 49.1 & 44.8 & - & 46.3 & - & 47.3 & - & - & - & 48.0 & 46.4 & - \\
\hline $\mathrm{Ta}$ & 0.16 & - & 0.193 & 0.183 & - & 0.19 & - & 0.199 & - & - & - & 0.14 & 0.118 & - \\
\hline Th & 0.162 & - & 0.14 & 0.17 & - & 0.13 & - & 0.11 & - & - & - & 0.11 & 0.131 & - \\
\hline $\mathrm{U}$ & 0.069 & - & 0.70 & 0.065 & - & 0.20 & 一 & 0.40 & - & - & - & 0.50 & 0.043 & - \\
\hline \multicolumn{15}{|c|}{ Rare earth elements (ppm) } \\
\hline $\mathrm{La}$ & 4.41 & - & 4.04 & 4.26 & - & 3.34 & - & 3.72 & - & - & - & 2.64 & 3.45 & - \\
\hline $\mathrm{Ce}$ & 13.02 & - & 12.80 & 12.75 & - & 10.70 & - & 11.30 & - & - & - & 8.50 & 10.72 & - \\
\hline $\operatorname{Pr}$ & 2.18 & - & - & 2.12 & - & - & - & - & - & - & - & - & 2.07 & - \\
\hline $\mathrm{Nd}$ & 12.64 & - & 12.00 & 12.27 & - & 11.00 & - & 12.00 & - & - & - & 12.00 & 10.92 & - \\
\hline $\mathrm{Sm}$ & 4.00 & - & 4.40 & 4.02 & - & 4.11 & - & 4.04 & - & - & - & 3.29 & 3.38 & - \\
\hline $\mathrm{Eu}$ & 1.51 & - & 1.57 & 1.51 & - & 1.45 & - & 1.48 & - & - & - & 1.27 & 1.32 & - \\
\hline Gd & 5.97 & - & - & 6.03 & - & - & - & - & - & - & - & - & 5.20 & - \\
\hline $\mathrm{Tb}$ & - & - & 1.00 & - & - & 1.04 & - & 1.05 & - & - & - & 0.88 & - & - \\
\hline Dy & 7.28 & - & - & 7.43 & - & - & - & - & - & - & - & - & 6.35 & - \\
\hline Ho & 1.44 & - & - & 1.48 & - & - & - & - & - & - & - & - & 1.27 & - \\
\hline $\mathrm{Er}$ & 4.32 & - & - & 4.38 & - & - & - & - & - & - & - & - & 3.83 & - \\
\hline $\mathrm{Yb}$ & 4.23 & - & 3.45 & 4.32 & - & 4.04 & - & 4.07 & - & - & - & 3.47 & 3.69 & - \\
\hline $\mathrm{Lu}$ & 0.71 & - & 0.511 & 0.74 & - & 0.605 & - & 0.626 & - & - & - & 0.53 & 0.64 & - \\
\hline
\end{tabular}

series of OIB governed by olivine + plagioclase and later plagioclase + clinopyroxene fractionation (Basaltic Volcanism Study Project, 1981). As illustrated in Figures 11 and 12, the primitive and evolved chemical groups represent a single coherent suite. The variation throughout is related mainly to olivine + plagioclase fractionation (especially in the primitive group), which is joined by clinopyroxene and titanomagnetite (and possibly minor biotite) in the evolved group. Like the tholeiites, the alkalic basalts also display parallel REE patterns (Fig. 11) typical of the involvement of non-REE fractionating phases during progressive crystallization (e.g., olivine and plagio- clase). To obtain the most evolved composition from a selected "parental" composition from among the primitive group (e.g., Sample 129-801-43R-01, 128-134 cm; with $\mathrm{MgO} 10.58$ wt $\%, \mathrm{TiO}_{2} 2.48 \mathrm{wt} \%$, Ni $375 \mathrm{ppm}, \mathrm{Cr} 323 \mathrm{ppm}$, and Zr $208 \mathrm{ppm}$ ), approximately $60 \%$ fractionation of $45 \%$ olivine, $10 \%$ plagioclase, $40 \%$ clinopyroxene, and $5 \%$ biotite and/or amphibole is required.

As in the tholeiitic sequence, there is no evidence to suggest that the primitive and evolved chemical groups of the alkalic basalts represent discrete magma batches produced by different degrees of partial melting from a common source or different sources. The 
Table 4 (continued).

\begin{tabular}{|c|c|c|c|c|c|c|c|c|c|c|c|c|c|c|}
\hline Core, section: & 9R-5 & 10R-1 & 10R-2 & $10 \mathrm{R}-3$ & $10 \mathrm{R}-4$ & $10 \mathrm{R}-5$ & 10R-5 & 10R-5 & $10 \mathrm{R}-6$ & $10 \mathrm{R}-6$ & $10 \mathrm{R}-6$ & $11 \mathrm{R}-1$ & $11 \mathrm{R}-1$ & $11 \mathrm{R}-2$ \\
\hline Interval (cm): & $20-24$ & $55-60$ & $25-31$ & $121-127$ & $64-70$ & $53-58$ & $62-67$ & $99-104$ & $21-26$ & $47-52$ & $67-70$ & $18-23$ & $121-126$ & $81-86$ \\
\hline Depth (mbsf): & 568.81 & 569.55 & 570.75 & 573.13 & 574.06 & 575.34 & 575.43 & 575.80 & 576.37 & 576.63 & 576.83 & 578.08 & 579.11 & 580.11 \\
\hline Cooling unit: & $\mathrm{C} 25$ & $\mathrm{C} 25$ & $\mathrm{C} 25$ & $\mathrm{C} 25$ & $\mathrm{C} 25$ & $\mathrm{C} 25$ & $\mathrm{C} 25$ & $\mathrm{C} 25$ & $\mathrm{C} 25$ & $\mathrm{C} 25$ & $\mathrm{C} 25$ & $\mathrm{C} 27$ & $\mathrm{C} 27$ & $\mathrm{C} 27$ \\
\hline \multicolumn{15}{|c|}{ Major oxides (wt $\%$ ) } \\
\hline $\mathrm{SiO}_{2}$ & 49.10 & 49.44 & 49.60 & 48.92 & 48.73 & 49.42 & 49.46 & 49.73 & 48.77 & 48.73 & 48.64 & 47.99 & 48.45 & 49.02 \\
\hline $\mathrm{TiO}_{2}$ & 1.71 & 1.62 & 1.63 & 1.59 & 1.57 & 1.59 & 1.62 & 1.63 & 1.64 & 1.61 & 1.78 & 2.30 & 2.19 & 2.18 \\
\hline $\mathrm{Al}_{2} \mathrm{O}_{3}$ & 14.05 & 14.02 & 14.01 & 14.03 & 13.92 & 13.90 & 14.03 & 13.98 & 14.12 & 14.07 & 14.55 & 14.64 & 14.18 & 13.66 \\
\hline $\mathrm{Fe}_{2} \mathrm{O}_{3}$ & 3.49 & 3.82 & 3.82 & 3.72 & 3.06 & (12.83) & 3.88 & 3.77 & (11.95) & 3.76 & 3.95 & 5.66 & 5.04 & $(13.84)$ \\
\hline $\mathrm{FeO}$ & 7.81 & 8.15 & 8.29 & 7.88 & 8.56 & - & 7.98 & 8.12 & - & 7.44 & 6.14 & 6.80 & 7.26 & - \\
\hline $\mathrm{MnO}$ & 0.18 & 0.18 & 0.19 & 0.19 & 0.20 & 0.19 & 0.18 & 0.18 & 0.18 & 0.19 & 0.16 & 0.16 & 0.19 & 0.21 \\
\hline $\mathrm{MgO}$ & 7.19 & 7.28 & 7.33 & 7.59 & 7.06 & 7.18 & 7.09 & 7.25 & 6.99 & 7.14 & 7.12 & 6.77 & 6.80 & 6.63 \\
\hline $\mathrm{CaO}$ & 11.73 & 11.95 & 11.74 & 12.04 & 12.47 & 12.12 & 12.01 & 11.83 & 12.66 & 12.58 & 12.26 & 10.86 & 11.86 & 11.27 \\
\hline $\mathrm{Na}_{2} \mathrm{O}$ & 2.62 & 2.56 & 2.67 & 2.59 & 2.53 & 2.59 & 2.62 & 2.62 & 2.73 & 2.78 & 2.77 & 2.90 & 2.81 & 2.78 \\
\hline $\mathrm{K}_{2} \tilde{\mathrm{O}}$ & 0.05 & 0.06 & 0.06 & 0.03 & 0.04 & 0.07 & 0.06 & 0.06 & 0.07 & 0.08 & 0.07 & 0.07 & 0.06 & 0.07 \\
\hline $\mathrm{P}_{2} \mathrm{O}_{5}$ & 0.06 & 0.06 & 0.06 & 0.05 & 0.05 & 0.20 & 0.05 & 0.13 & 0.20 & 0.06 & 0.06 & 0.15 & 0.11 & 0.12 \\
\hline LOI & 1.31 & 1.08 & 1.04 & 1.04 & 1.25 & 0.28 & 1.01 & 1.16 & 0.66 & 1.72 & 2.19 & 1.44 & 1.34 & 0.28 \\
\hline Total & 99.31 & 100.23 & 100.43 & 99.67 & 99.45 & 100.36 & 100.00 & 100.46 & 99.99 & 100.16 & 99.69 & 99.74 & 100.29 & 100.07 \\
\hline $\mathrm{H}_{2} \mathrm{O}+$ & 0.97 & 0.55 & 0.57 & 0.66 & 0.54 & - & 0.58 & 0.59 & - & 0.55 & 1.03 & 0.91 & 0.71 & 0.56 \\
\hline $\mathrm{CO}_{2}$ & 0.20 & 0.28 & 0.14 & 0.13 & 0.54 & - & 0.23 & 0.02 & - & 1.05 & 1.00 & 0.54 & 0.53 & 0.43 \\
\hline \multicolumn{15}{|c|}{ Trace elements by XRF (ppm) } \\
\hline $\mathrm{Ba}$ & 16 & 14 & 24 & 21 & 16 & 14 & 14 & 9 & 18 & 25 & 9 & 25 & 26 & 27 \\
\hline $\mathrm{Ce}$ & 7 & 11 & 10 & 9 & 8 & 10 & 9 & 11 & 10 & 10 & 4 & 16 & 17 & 15 \\
\hline $\mathrm{Cr}$ & 203 & 175 & 171 & 199 & 205 & 200 & 187 & 193 & 199 & 187 & 200 & 199 & 188 & 170 \\
\hline $\mathrm{Cu}$ & 78 & 75 & 75 & 76 & 75 & 74 & 75 & 76 & 76 & 74 & 78 & 72 & 71 & 69 \\
\hline $\mathrm{Ga}$ & 21 & 19 & 19 & 20 & 19 & 16 & 19 & 21 & 16 & 17 & 19 & 21 & $2 \mathrm{I}$ & 20 \\
\hline $\mathrm{La}$ & 2 & 3 & 2 & 2 & 2 & 3 & 2 & 3 & 2 & 3 & 1 & 4 & 5 & 5 \\
\hline $\mathrm{Nb}$ & 4 & 5 & 4 & 4 & 4 & 4 & 4 & 4 & 4 & 4 & 4 & 7 & 7 & 6 \\
\hline $\mathrm{Nd}$ & 9 & 12 & 11 & 10 & 9 & 12 & 11 & 12 & 9 & 10 & 4 & 18 & 21 & 21 \\
\hline $\mathrm{Ni}$ & 69 & 70 & 65 & 72 & 70 & 67 & 71 & 68 & 70 & 69 & 67 & 66 & 66 & 64 \\
\hline $\mathrm{Pb}$ & 6 & 6 & 8 & 8 & 6 & 5 & 3 & 7 & 6 & 4 & 3 & 6 & 6 & 8 \\
\hline $\mathrm{Rb}$ & 1 & 1 & 1 & 2 & 1 & 4 & 1 & 1 & 3 & 3 & 1 & 1 & 1 & 1 \\
\hline $\mathrm{S}$ & 670 & 602 & 595 & 565 & 617 & 487 & 571 & 576 & 516 & 431 & 275 & 323 & 249 & 608 \\
\hline $\mathrm{Sr}$ & 108 & 113 & 110 & 113 & 115 & 112 & 112 & 108 & 120 & 125 & 118 & 140 & 137 & 129 \\
\hline V & 368 & 365 & 360 & 363 & 357 & 347 & 355 & 358 & 349 & 371 & 408 & 488 & 439 & 404 \\
\hline $\mathrm{Y}$ & 37 & 38 & 37 & 37 & 37 & 36 & 38 & 38 & 37 & 36 & 38 & 46 & 44 & 45 \\
\hline $\mathrm{Zn}$ & 93 & 85 & 91 & 89. & 84 & 80 & 83 & 83 & 86 & 90 & 95 & 109 & 106 & 101 \\
\hline $\mathrm{Zr}$ & 95 & 97 & 95 & 94 & 95 & 93 & 96 & 95 & 96 & 96 & 101 & 149 & 141 & 138 \\
\hline
\end{tabular}

\begin{tabular}{|c|c|c|c|c|c|c|c|c|c|c|c|c|c|c|}
\hline \multicolumn{15}{|c|}{ Trace elements by INAA (ppm) } \\
\hline Cs & 0.17 & 0.045 & - & - & - & - & - & - & - & - & 0.10 & - & 0.10 & - \\
\hline Hf & 2.55 & 2.40 & - & - & - & - & - & - & - & - & 2.60 & - & 3.50 & - \\
\hline $\mathrm{Se}$ & 46.3 & 45.0 & - & - & - & - & - & - & - & - & 45.9 & - & 44.2 & - \\
\hline $\mathrm{Ta}$ & 0.126 & 0.125 & - & - & - & - & - & - & - & - & 0.124 & - & 0.24 & - \\
\hline $\mathrm{Th}$ & 0.11 & 0.117 & - & - & - & - & - & - & - & - & 0.109 & - & 0.25 & - \\
\hline $\mathrm{U}$ & 0.30 & 0.045 & - & - & - & - & - & - & - & - & 0.10 & - & 0.08 & 一 \\
\hline \multicolumn{15}{|c|}{ Rare earth elements (ppm) } \\
\hline $\mathrm{La}$ & 2.75 & 3.48 & - & - & - & - & - & - & - & - & 3.26 & - & 4.94 & - \\
\hline $\mathrm{Ce}$ & 8.80 & 10.78 & - & - & - & - & - & - & - & - & 10.08 & - & 14.71 & - \\
\hline $\operatorname{Pr}$ & - & 2.06 & - & - & - & - & - & - & - & - & 1.78 & - & 2.48 & - \\
\hline Nd & 7.00 & 10.65 & - & - & - & - & - & - & - & - & 10.38 & - & 13.45 & - \\
\hline $\mathrm{Sm}$ & 3.38 & 3.44 & - & - & - & - & - & - & - & - & 3.33 & - & 4.30 & - \\
\hline $\mathrm{Eu}$ & 1.28 & 1.33 & - & - & - & - & - & - & - & - & 1.30 & - & 1.62 & - \\
\hline Gd & - & 5.20 & - & - & - & - & - & - & - & - & 5.01 & - & 6.42 & - \\
\hline $\mathrm{Tb}$ & 0.94 & - & - & - & - & - & - & - & - & - & - & - & - & - \\
\hline Dy & - & 6.38 & - & - & - & - & - & - & - & - & 6.24 & - & 7.67 & - \\
\hline Но & - & 1.27 & - & - & - & - & - & - & - & - & 1.24 & - & 1.52 & - \\
\hline $\mathrm{Er}$ & - & 3.83 & - & - & - & - & - & - & - & - & 3.71 & - & 4.51 & - \\
\hline $\mathrm{Yb}$ & 3.53 & 3.69 & - & - & - & - & - & - & - & - & 3.68 & - & 4.46 & - \\
\hline $\mathrm{Lu}$ & 0.53 & 0.62 & - & - & - & - & - & - & - & - & 0.62 & - & 0.73 & - \\
\hline
\end{tabular}

chemical variation can apparently be accommodated via simple fractionation, that could imply the existence of a single magma chamber. However, in terms of the timing of extrusion on the seafloor, the primitive group punctuates (with the exception of a few oxidized samples) a chemically homogeneous set of evolved group lavas (Fig. 9) and marks a chemical break in the sequence. Once again these features could indicate the operation of open-system fractionation with the primitive group heralding a massive influx of "parental" melt that interrupted the fractionation process in the magma chamber. The parental melt subsequently underwent fractionation, eventually producing a set of differentiated primitive group lavas followed by evolved group lavas toward the top of the basement sequence.

\section{COMPARISON WITH OTHER OCEANIC BASALTS}

The one unexpected feature of the Jurassic crust at Site 801 was the thin carapace of alkalic basalts associated with tholeiites typical of the ocean floor worldwide. The tholeiites are N-MORB with chemi- 
Table 4 (continued).

\begin{tabular}{|c|c|c|c|c|c|c|c|c|c|}
\hline Core, section: & 1IR-2 & $11 \mathrm{R}-3$ & $11 R-3$ & $12 \mathrm{R}-1$ & $12 \mathrm{R}-2$ & $12 \mathrm{R}-2$ & $12 \mathrm{R}-3$ & $12 \mathrm{R}-3$ & $12 \mathrm{R}-3$ \\
\hline Interval $(\mathrm{cm})$ : & $131-136$ & $14-18$ & $121-126$ & $101-104$ & $44-49$ & $103-109$ & $32-37$ & $57-62$ & $86-90$ \\
\hline Depth (mbsf): & 580.16 & 580.94 & 582.01 & 588.31 & 589.24 & 589.83 & 590.58 & 590.83 & 591.12 \\
\hline Cooling unit: & $\mathrm{C} 28$ & $\mathrm{C} 28$ & $\mathrm{C} 29$ & $\mathrm{C} 31$ & $\mathrm{C} 32$ & $\mathrm{C} 32$ & C32 & C 32 & $\mathrm{C} 32$ \\
\hline \multicolumn{10}{|c|}{ Major oxides (wt $\%$ ) } \\
\hline $\mathrm{SiO}_{2}$ & 47.19 & 48.90 & 46.01 & 48.27 & 49.37 & 48.55 & 48.49 & 48.90 & 48.44 \\
\hline $\mathrm{TiO}_{2}$ & 2.11 & 1.95 & 1.95 & 2.39 & 2.51 & 2.26 & 2.30 & 2.29 & 2.16 \\
\hline $\mathrm{Al}_{2} \mathrm{O}_{3}$ & 15.15 & 14.44 & 14.52 & 14.66 & 14.90 & 13.26 & 13.25 & 13.58 & 13.53 \\
\hline $\mathrm{Fe}_{2} \mathrm{O}_{3}$ & 5.19 & 3.86 & 4.13 & 6.35 & 5.80 & 4.15 & 3.63 & 4.61 & 4.45 \\
\hline $\mathrm{FeO}$ & 6.64 & 8.07 & 8.24 & 6.65 & 5.90 & 8.91 & 8.78 & 7.96 & 8.66 \\
\hline $\mathrm{MnO}$ & 0.16 & 0.19 & 0.19 & 0.19 & 0.17 & 0.23 & 0.22 & 0.22 & 0.24 \\
\hline $\mathrm{MgO}$ & 6.00 & 5.83 & 5.26 & 6.55 & 6.45 & 6.55 & 6.80 & 6.83 & 6.78 \\
\hline $\mathrm{CaO}$ & 12.01 & 12.02 & 12.54 & 10.15 & 9.92 & 11.29 & 11.30 & 11.11 & 11.47 \\
\hline $\mathrm{Na}_{2} \mathrm{O}$ & 2.59 & 2.51 & 2.57 & 2.98 & 3.28 & 2.80 & 2.79 & 2.82 & 2.68 \\
\hline $\mathrm{K}_{2} \mathrm{O}$ & 0.10 & 0.11 & 0.09 & 0.26 & 0.06 & 0.09 & 0.04 & 0.08 & 0.04 \\
\hline $\mathrm{P}_{2} \mathrm{O}_{5}$ & 0.17 & 0.10 & 0.10 & 0.14 & 0.14 & 0.12 & 0.19 & 0.12 & 0.12 \\
\hline LOI & 2.29 & 1.69 & 4.60 & 1.36 & 1.44 & 1.38 & 1.22 & 1.07 & 1.11 \\
\hline Total & 99.60 & 99.68 & 100.20 & 99.96 & 99.94 & 99.61 & 99.00 & 99.58 & 99.77 \\
\hline $\mathrm{H}_{2} \mathrm{O}+$ & 1.32 & 0.81 & 0.86 & 1.08 & 1.04 & 0.93 & 0.51 & 0.79 & 0.55 \\
\hline $\mathrm{CO}_{2}$ & 0.81 & 0.67 & 3.44 & 0.33 & 0.49 & 0.28 & 0.27 & 0.10 & 0.38 \\
\hline
\end{tabular}

$\begin{array}{lrrrrrrrrr}\text { Trace elements by XRF (ppm) } & & & & & & & & \\ \mathrm{Ba} & 16 & 2 & 32 & 11 & 22 & 24 & 22 & 25 & 17 \\ \mathrm{Ce} & 8 & 5 & 18 & 15 & 18 & 15 & 9 & 17 & 18 \\ \mathrm{Cr} & 318 & 292 & 315 & 122 & 101 & 106 & 93 & 101 & 106 \\ \mathrm{Cu} & 69 & 68 & 66 & 76 & 70 & 71 & 74 & 73 & 71 \\ \mathrm{Ga} & 18 & 21 & 18 & 21 & 23 & 18 & 22 & 21 & 22 \\ \mathrm{La} & 2 & 1 & 4 & 4 & 5 & 4 & 2 & 4 & 4 \\ \mathrm{Nb} & 5 & 4 & 5 & 6 & 6 & 5 & 5 & 5 & 5 \\ \mathrm{Nd} & 10 & 7 & 21 & 15 & 21 & 19 & 11 & 19 & 20 \\ \mathrm{Ni} & 88 & 86 & 67 & 58 & 56 & 59 & 56 & 60 & 57 \\ \mathrm{~Pb} & 6 & 7 & 4 & 5 & 5 & 6 & 5 & 6 & 8 \\ \mathrm{Rb} & 4 & 2 & 3 & 6 & 1 & 3 & 1 & 2 & 1 \\ \mathrm{~S} & 490 & 441 & 443 & 430 & 331 & 563 & 574 & 623 & 569 \\ \mathrm{Sr} & 112 & 110 & 113 & 134 & 142 & 121 & 121 & 119 & 122 \\ \mathrm{~V} & 441 & 386 & 401 & 518 & 551 & 427 & 437 & 458 & 432 \\ \mathrm{Y} & 44 & 44 & 45 & 51 & 58 & 49 & 49 & 49 & 49 \\ \mathrm{Zn} & 111 & 103 & 111 & 124 & 109 & 110 & 101 & 108 & 104 \\ \mathrm{Zr} & 126 & 124 & 122 & 153 & 161 & 143 & 143 & 144 & 141\end{array}$

\begin{tabular}{|c|c|c|c|c|c|c|c|c|c|}
\hline \multicolumn{10}{|c|}{ Trace elements by INAA (ppm) } \\
\hline Cs & 0.40 & - & 0.10 & - & - & - & 0.20 & 0.30 & - \\
\hline $\mathrm{Hf}$ & 3.19 & - & 3.20 & - & - & - & 3.75 & 3.83 & - \\
\hline $\mathrm{Sc}$ & 44.1 & - & 42.0 & - & - & - & 47.3 & 46.8 & - \\
\hline $\mathrm{Ta}$ & 0.154 & - & 0.151 & - & - & - & 0.22 & 0.23 & - \\
\hline $\mathrm{Th}$ & 0.07 & - & 0.13 & - & - & - & 0.16 & 0.14 & - \\
\hline $\mathrm{U}$ & 0.60 & - & 0.082 & - & - & - & 0.60 & 0.40 & - \\
\hline \multicolumn{10}{|c|}{ Rare earth elements (ppm) } \\
\hline $\mathrm{La}$ & 3.34 & - & 3.87 & - & - & - & 4.33 & 4.31 & - \\
\hline $\mathrm{Ce}$ & 10.80 & - & 12,28 & - & - & - & 14.30 & 13.20 & - \\
\hline Pr & - & - & 1.99 & - & - & - & - & - & - \\
\hline Nd & 10.00 & - & 12.00 & - & - & - & 19.0 & 14.0 & 一 \\
\hline $\mathrm{Sm}$ & 4.25 & - & 3.96 & - & - & - & 4.71 & 4.83 & 一 \\
\hline $\mathrm{Eu}$ & 1.46 & - & 1.48 & - & - & - & 1.66 & 1.65 & - \\
\hline Gd & - & - & 5.95 & - & - & - & - & - & - \\
\hline $\mathrm{Tb}$ & 1.05 & - & - & - & - & - & 1.24 & 1.24 & - \\
\hline Dy & - & - & 7.43 & - & - & - & - & - & - \\
\hline Ho & - & - & 1.48 & - & - & - & - & - & - \\
\hline Er & - & - & 4.33 & - & - & - & - & - & - \\
\hline $\mathrm{Yb}$ & 4.08 & - & 4.30 & - & - & - & 4.72 & 4.71 & - \\
\hline $\mathrm{Lu}$ & 0.614 & - & 0.730 & - & - & - & 0.698 & 0.696 & - \\
\hline
\end{tabular}

$\mathrm{cal}$ and isotopic features indicative of derivation from an incompatible-element-depleted mantle source. The alkalic basalts are chemically and isotopically distinctive and were derived from a correspondingly enriched "within-plate" OIB-type source. As seen in Figure 14 their marked separation relative to primitive mantle values, together with similar differences in $\mathrm{Sr}$ and $\mathrm{Nd}$ isotopic ratios (Castillo et al., this volume), clearly suggests that two separate sources were involved in their generation. The nature of the eruptive environment within which these diverse magma types developed will be briefly discussed in the following sections.

\section{Mid-ocean Ridge Basalts}

The only other Jurassic ocean crust of comparable age is in the Atlantic Ocean. This was sampled during DSDP Leg 11, Sites 100 and 105 (northwest American continental rise; e.g., Ayuso et al., 1976; Bryan et al., 1977); DSDP Leg 41, Site 367 (Cape Verde Basin; e.g., Natland, 1977); and DSDP Leg 76 (Blake-Bahama Basin; e.g., Logothetis, 1983). Also, the oldest volcanics exposed on Maio in the Cape Verde Islands are a series of uplifted Mesozoic pillow lavas with typical MORB features (de Paepe et al., 1974; Stillman et al., 1982). 

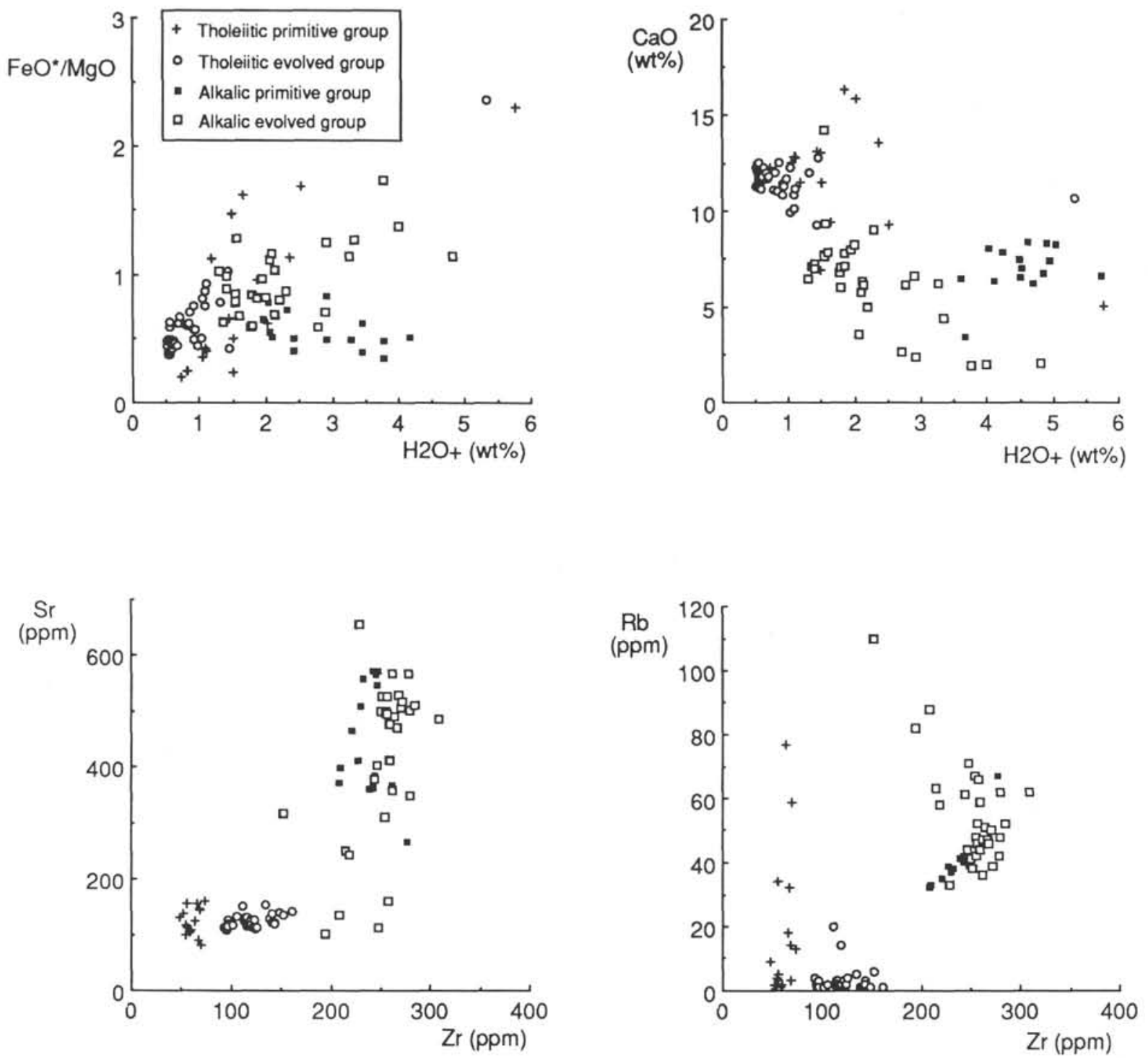

Figure 5. Variation of chemical parameters with alteration in Site 801 basalts. $\mathrm{CaO}$ markedly decreases and $\mathrm{FeO} * \mathrm{MgO}$ slightly increases with hydration and both $\mathrm{Rb}$ and $\mathrm{Sr}$ show variation dissimilar to normal magmatic trends relative to a stable element such as $\mathrm{Zr}$.

Chemically, the Atlantic Jurassic crust is similar to the Site 801 tholeiites and encompasses the full range shown by the majority of the primitive and evolved groups. Where chemical data are available, light-to-heavy REE fractionation $\left([\mathrm{La} / \mathrm{Yb}]_{N}\right.$ about $\left.0.4-0.6\right)$ is directly comparable, although $\mathrm{Zr} / \mathrm{Nb}$ ratios at Site 801 do not show the range or very high ratios especially exhibited at Sites 100 and 105 (about 16-20 and about 40-50 respectively, Ayuso et al., 1976).

Site $801 \mathrm{~N}-\mathrm{MORB}$ is also comparable with spreading-axis basalts in the Pacific Ocean from the Nazca Plate (e.g., Rhodes et al., 1976), Costa Rica Rift (e.g., Marsh et al., 1983; Tual et al., 1985) and segments of the East Pacific Rise (EPR) (e.g., Thompson et al., 1989). In terms of chondrite-normalized REE patterns, both the primitive and evolved groups are encompassed by recent Pacific N-MORB (Fig. 15), although very depleted light REE patterns $\left([\mathrm{La} / \mathrm{Yb}]_{N}\right.$ about $0.2-0.3)$ and negative Eu anomalies, as are sometimes developed in Costa Rica Rift basalts (Tual et al., 1985), are not present. Overall, Jurassic MORB from the Pacific springs no surprises and has chemical analogues in much younger, more recent crust, which indicates that a broadly similar mantle and melting processes have been involved in its generation for more than $175 \mathrm{Ma}$.

\section{Ocean Island Basalts}

OIBs show a wide range of composition and incompatible element enrichment relative to that of MORB and in this respect, Site 801 alkalic basalts display characteristic features. In terms of incompatible element ratios they have values intermediate between those from sodic alkaline ocean islands such as St. Helena and the Caroline Islands (Floyd et al., 1991). This is also illustrated in Figure 16, in which Site 801 alkalic basalts group with OIB derived from a source with a high $\mu$-type (HIMU-type) mantle component characterized by low ${ }^{87} \mathrm{Sr} /{ }^{86} \mathrm{Sr}$ isotopic ratios and low $\mathrm{Ba} / \mathrm{Nb}$ and $\mathrm{La} / \mathrm{Nb}$ (Sun and McDonough, 1989). Although specific incompatible element ratios are not completely diagnostic of the HIMU mantle source, Site 801 alkalic basalts do have characteristically low $\mathrm{Sr}$ isotopic ratios (about 0.7028 ), although ${ }^{206} \mathrm{~Pb} /{ }^{204} \mathrm{~Pb}$ ratios (maximum about 19.30) do not approach the high values for St. Helena (about 21.0). Thus, on isotopic grounds the Site 801 alkalic basalts fall in an intermediate position between Tristan da Cunha and St. Helena (Castillo et al., this volume), similar to that indicated by the incompatible element ratios (Fig. 16). 


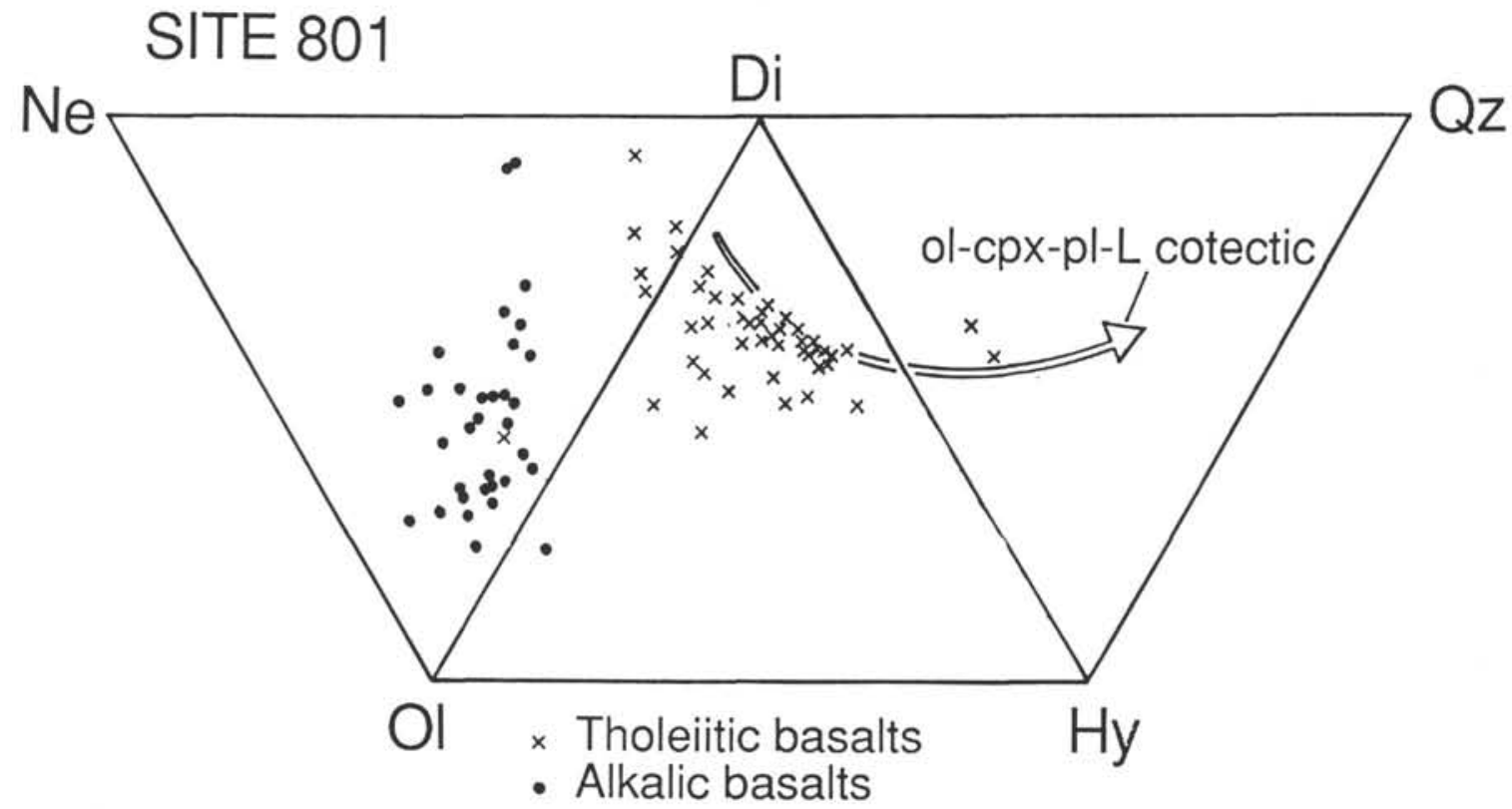

Figure 6. Distribution of Site 801 tholeiitic and alkalic basalts in the normative basalt trapezohedron compared with the field of ocean floor basalts (Basaltic Volcanism Study Project, 1981) and the olivine-clinopyroxene-plagioclase-liquid cotectic at 1 atm. (Thompson, 1982). $\mathrm{Ne}=$ nepheline, $\mathrm{Di}=$ diopside, $\mathrm{Qz}=$ quartz, $\mathrm{Ol}=$ olivine, $\mathrm{Hy}=$ hypersthene.

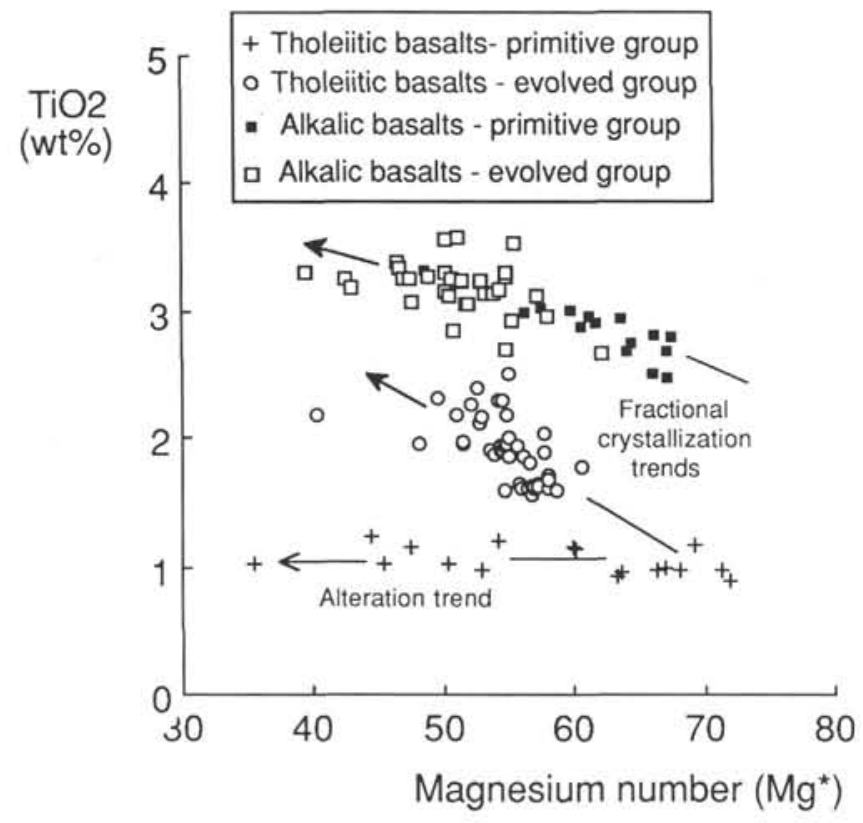

Figure 7. Differences in the distribution and abundance of $\mathrm{TiO}_{2}$ in the tholeiitic and alkalic basalt sequences relative to magnesium number $\left(\mathrm{Mg}^{*}\right)$ used as a fractionation index. Some of the low $\mathrm{TiO}_{2}$ tholeiites with a wide range of $\mathrm{Mg}^{*}$ are strongly altered.

\section{Eruptive Setting}

The extrusive nature and chemical features of the Site 801 tholeiitic sequence clearly indicate that these lavas represent the volcanic portion of the oceanic crust generated at the axis of a ridge system. Within the axial environment, the alkalic basalt sequence with typical OIB features appears anomalous, although alkaline magmas are found associated with MORB in a number of ridge settings:
1. Plume-elevated and/or incompatible element-enriched ridge segments (e.g., portions of the Mid-Atlantic Ridge; Tarney et al., 1979). In this case, however, the oceanic crust is composed of variably enriched tholeiites (T- or E-MORB), and not alkalic basalts similar to those at Site 801.

2. In the vicinity of ridge offsets and transforms (e.g., parts of the East Pacific Rise, Mathematician Ridge, Siqueiros transform; Batiza et al., 1977; Batiza and Johnson, 1980; Batiza and Vanko, 1985). The little chemical data available, however, suggest that these alkalic basalts have lower and more uniform $\mathrm{Ti}$ and other incompatible abundances than the relatively enriched Site 801 alkalic rocks (Floyd et al., 1991).

3. Near-ridge and axial seamounts (e.g., on the flanks of the East Pacific Rise; Batiza, 1977; Batiza, 1980; Batiza and Vanko, 1984). Although many of the seamounts closest to the axial zone are tholeiitic, with compositions similar to N-MORB (Batiza and Vanko, 1984; Zindler et al., 1984; Fornari et al., 1988; Allan et al., 1989), those developed on crust older than about $3 \mathrm{Ma}$ are much more diverse with both transitional and alkalic basalts (Batiza, 1980; Batiza and Vanko, 1984). Some older flank seamounts with tholeiitic pedestals may have later caps of minor alkalic lavas and characteristically show a full range of compositions from light REE-depleted tholeiites through transitional basalts to light REE-enriched alkalic basalts (Batiza and Vanko, 1984). This magma-type eruptive sequence is not dissimilar to the lithostratigraphy seen here and could suggest that the Site 801 volcanic sequence represents a section through a flank seamount, rather than "true" oceanic crust. In general, near-ridge and axial seamounts display two features: (1) the N-MORB-type tholeiites are commonly very primitive with high $\mathrm{Mg}^{*}$ (Allan et al., 1989) and probably represent separate melts derived directly from the mantle, and (2) compositionally varied seamounts show systematic chemical changes that are the result of simple binary melt mixing (Batiza and Vanko, 1984). As seen in Figure 17 the Site 801 data fall on the mixing line of East Pacific Rise (EPR) axial seamounts, but differ in two aspects: (1) with the exception of a few high-Mg* primitive group "parental" tholeiites, most of the Site 801 basalts cluster around typical EPR N-MORB, and (2) the Site 801 tholeiites and alkalic basalts form two distinct and separate groups with no intermediate compositions. Thus, it seems unlikely that the Site 801 alkalic basalts 


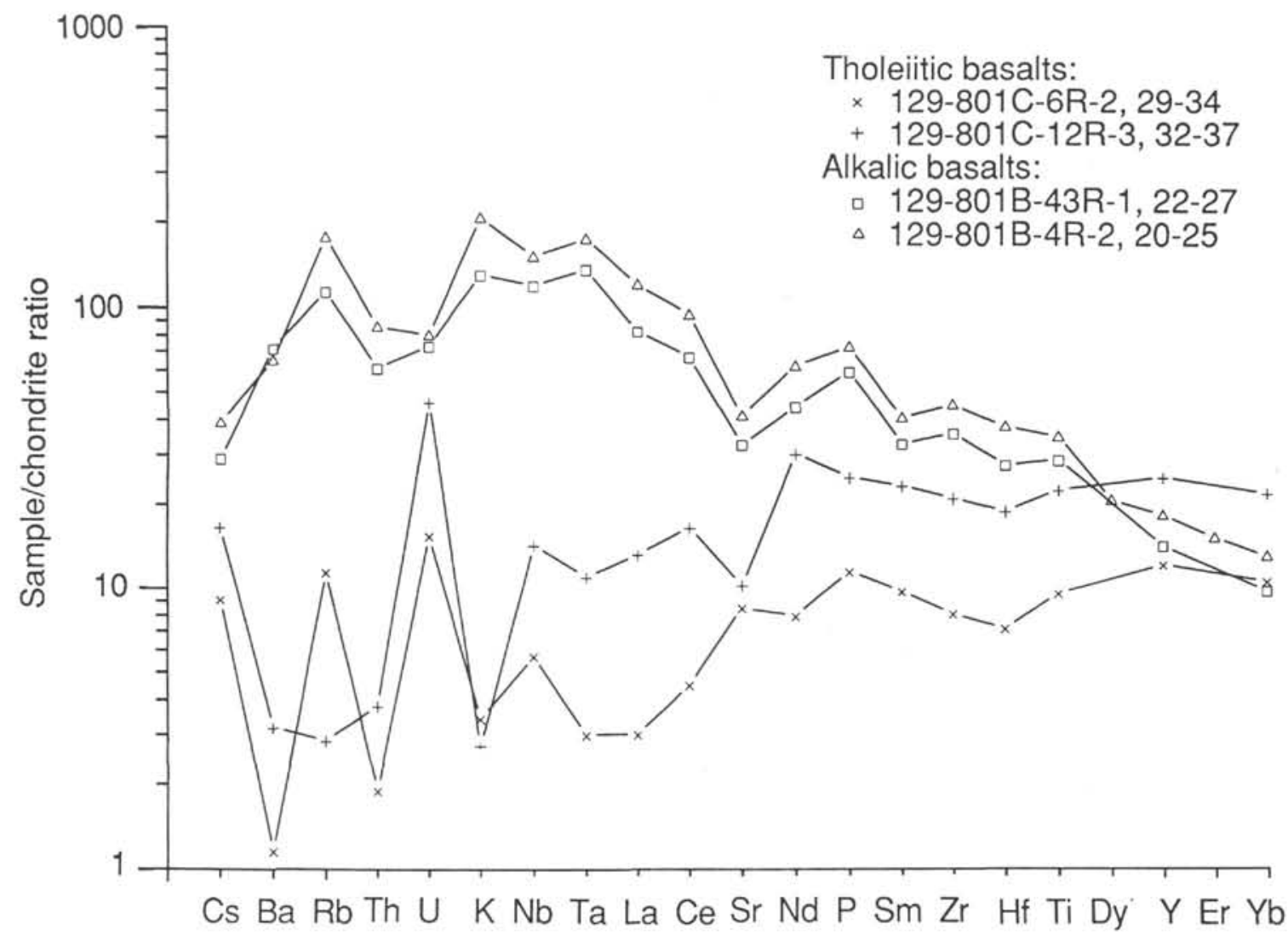

Figure 8. Examples of chondrite-normalized multielement patterns for the tholeiitic sequence (depleted pattern) and the alkalic sequence (enriched pattern) basalts. The patterns developed are similar to those of typical N-MORB and OIB, respectively.

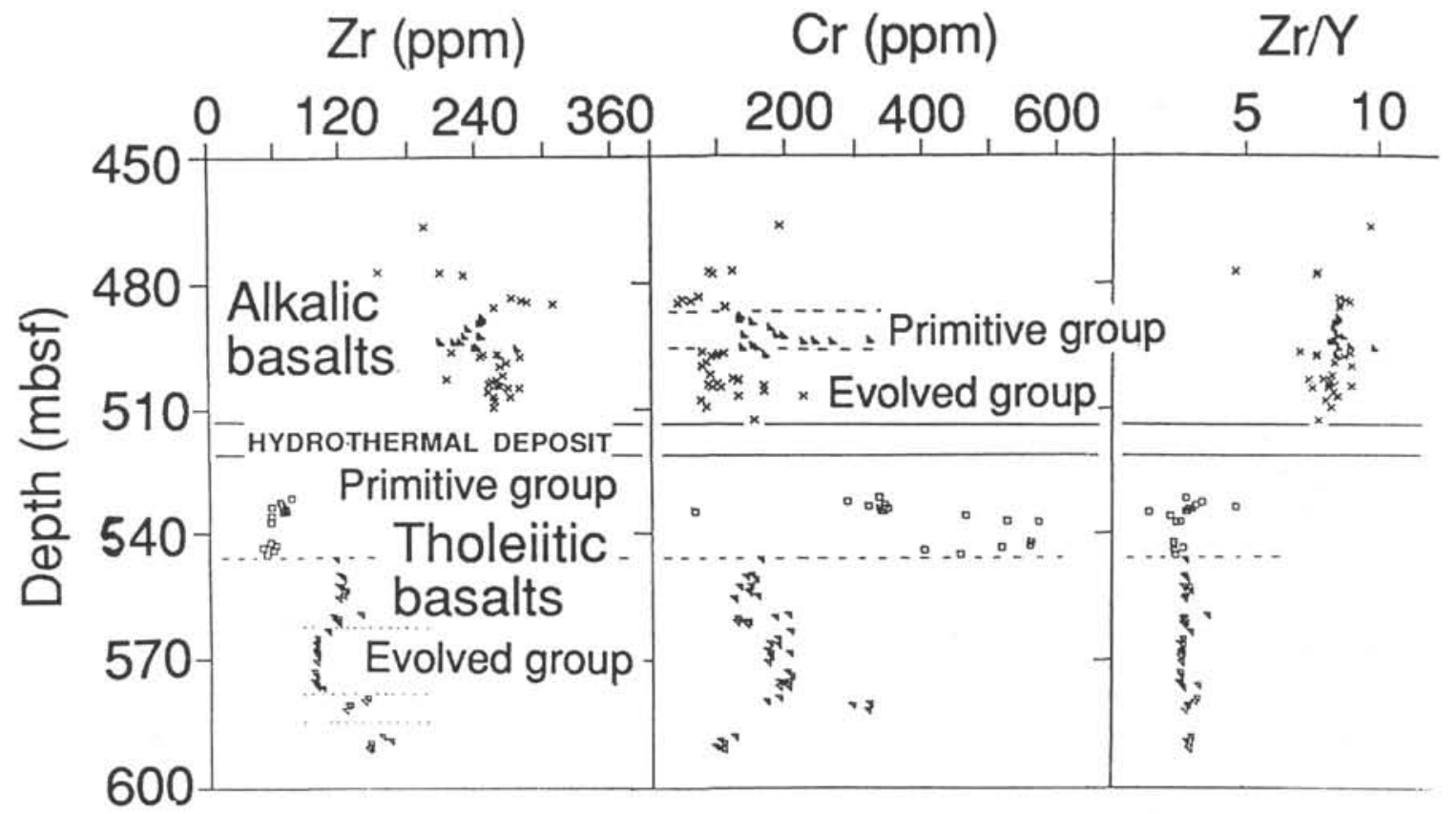

Figure 9. Chemostratigraphy of Site 801 showing the division of the tholeiitic and alkalic basalt sequences into primitive and evolved groups using the distribution of $\mathrm{Zr}$. Note the clear differences between the two magma type sequences as illustrated by ratios of incompatible elements (e.g., $\mathrm{Zr} / \mathrm{Y}$ ). 

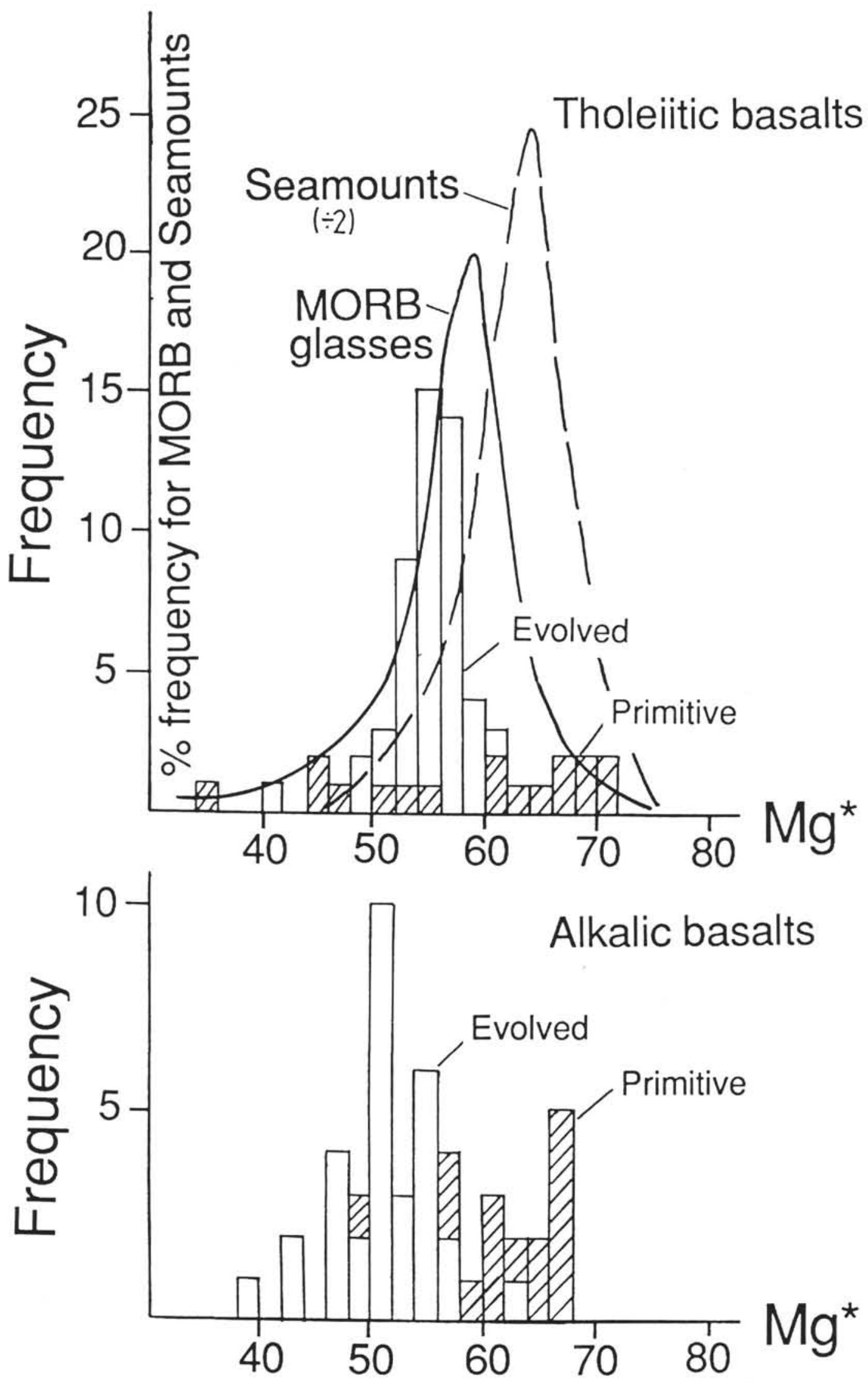

Figure 10. Frequency distribution of magnesium numbers $\left(\mathrm{Mg}^{*}\right)$ in Site 801 tholeiitic and alkalic basalts compared with data from ocean floor basaltic glasses (Basaltic Volcanism Study Project, 1981) and near-axis seamounts (Batiza and Vanko, 1984). 

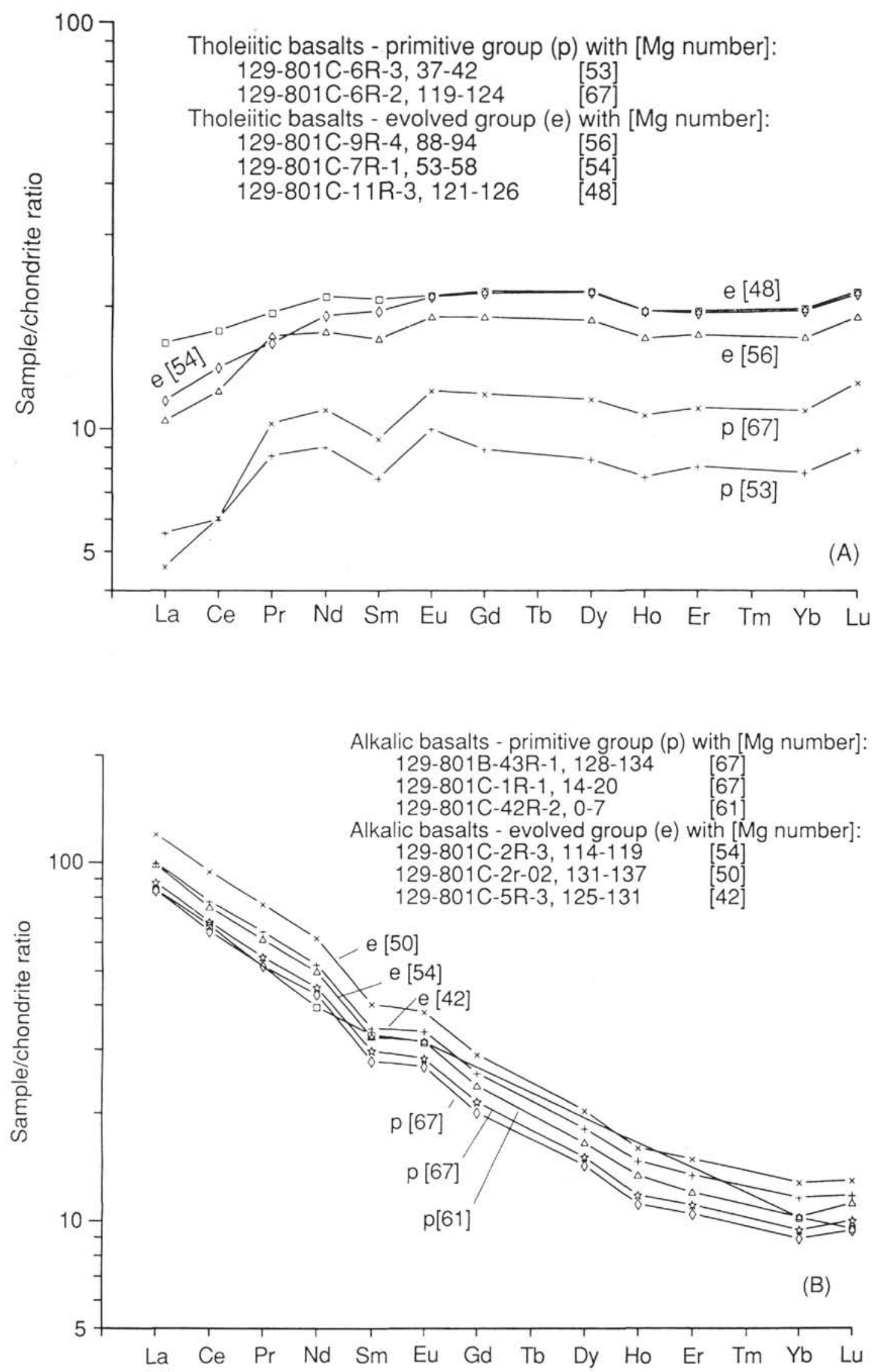

Figure 11. Chondrite-normalized REE distribution patterns for tholeiitic (A) and alkalic (B) basalts from Site 801. Magnesium numbers for each sample added in brackets. 

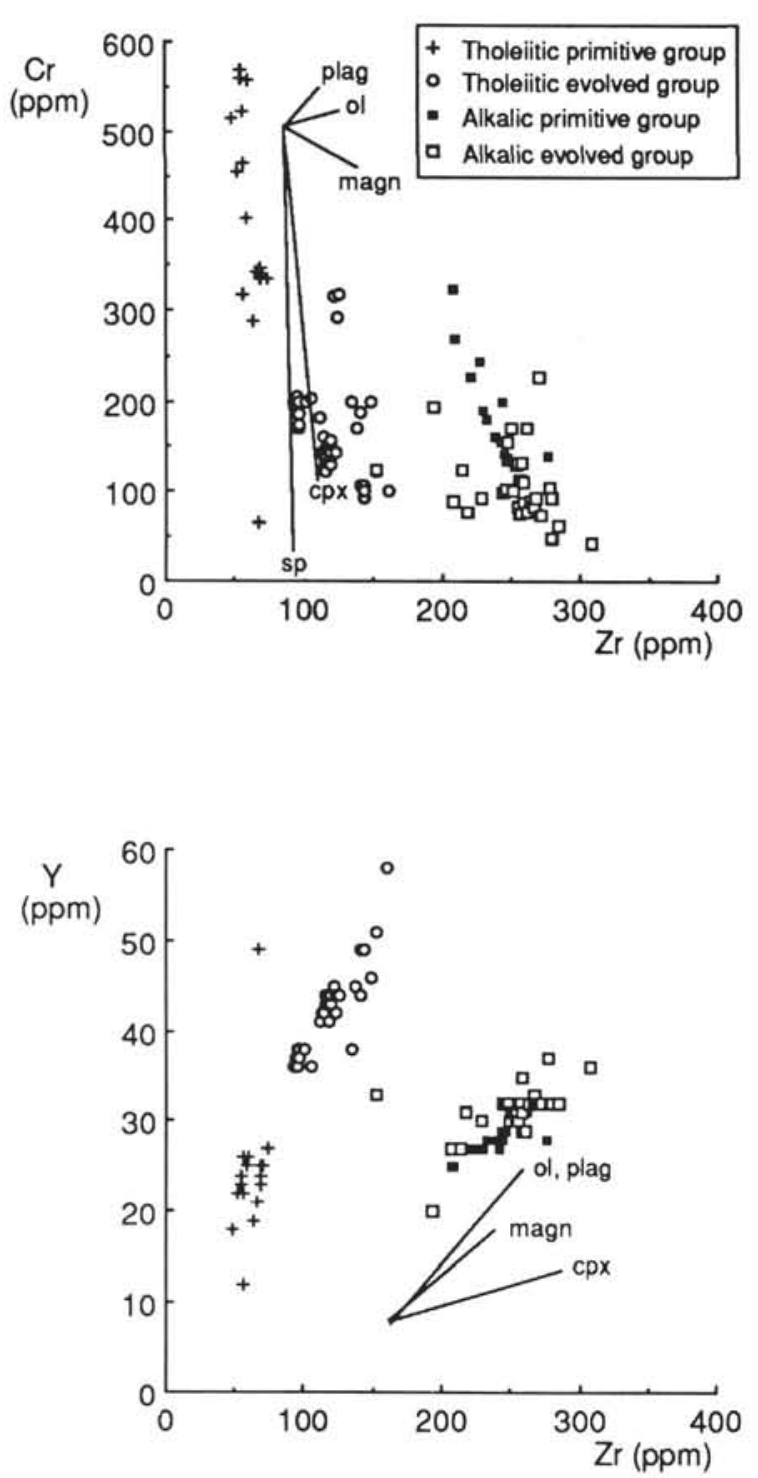
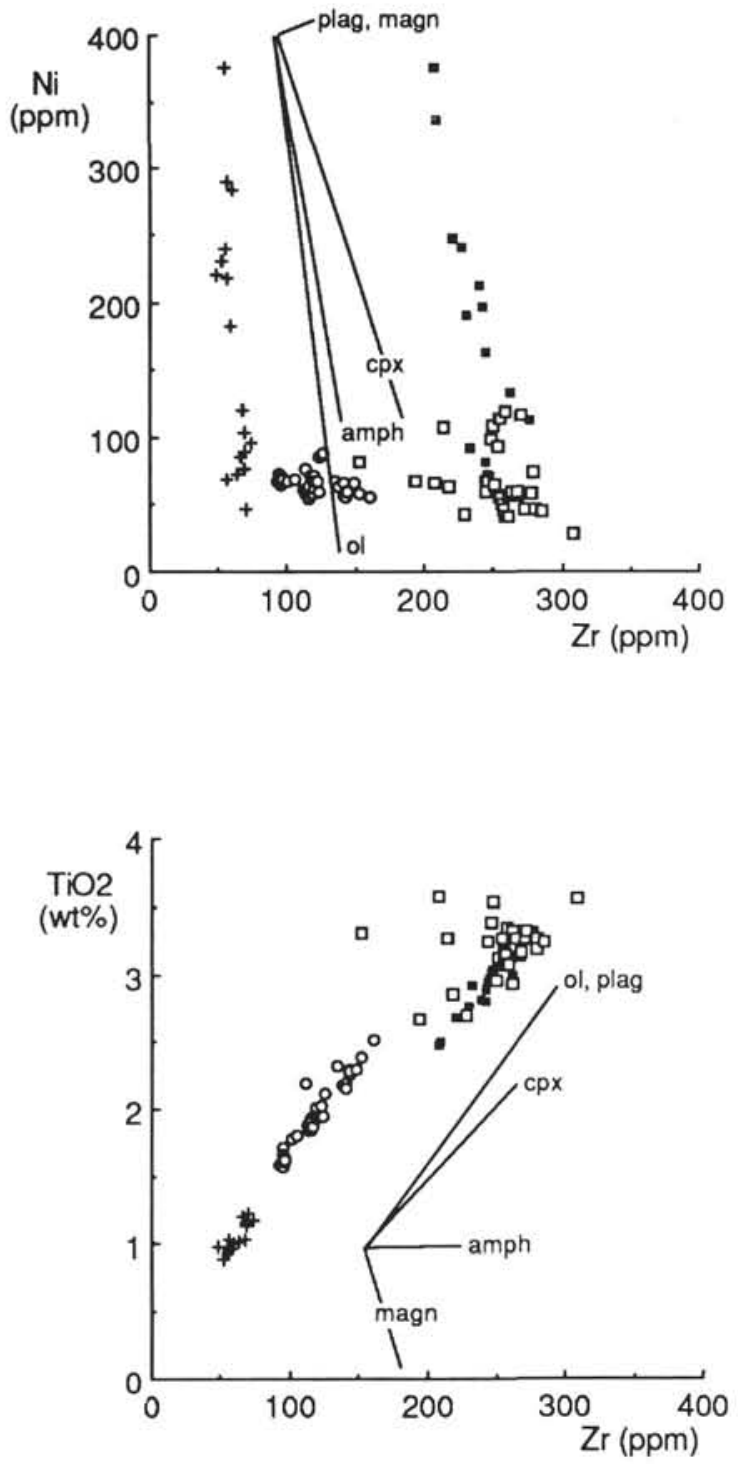

Figure 12. Distribution of $\mathrm{TiO}_{2}, \mathrm{Y}, \mathrm{Ni}$, and $\mathrm{Cr}$ relative to $\mathrm{Zr}$ (used as a fractionation index) in Site 801 tholeiitic and alkalic basalts. Note the chemical distinctions between the two basaltic sequences and the change in trend from the primitive to evolved tholeiites as a result of variable phase fractionation. Uniform, but different, $\mathrm{Ti} / \mathrm{Zr}$ and $\mathrm{Zr} / \mathrm{Y}$ ratios characterized the two sequences. Mineral fractionation vectors for $50 \%$ fractionation $(f=0.5)$ are also shown and illustrate the compositional control exerted by spinel, olivine, and plagioclase precipitation.

are an expression of late alkaline volcanism capping a flank or axial seamount. On the other hand, there are no data that would preclude Site 801 alkalic basalts representing an entirely off-axis seamount sitting on top of typical oceanic crust.

Some compositions, more incompatible element-enriched than N-MORB, have been found on or in the vicinity of the EPR. For example, Hekinian et al. (1989) described the association of compositionally distinct magmas in close proximity from both axial and off-axis (largely seamounts) settings on the EPR between about $11^{\circ}$ and $13^{\circ} \mathrm{N}$. However, the undepleted (non-N-MORB) basalts show much lower degrees of REE fractionation $\left([\mathrm{La} / \mathrm{Yb}]_{N}\right.$ about 1.5$)$, far higher $\mathrm{Zr} / \mathrm{Nb}$ ratios (10-18), and lower incompatible element abundances overall than those of the Site 801 alkalic basalts. A nephelinenormative alkalic basalt similar to those described here was found in Hole 602B (Leg 92) on the EPR (Pearce et al., 1986), and although similar to some within-plate OIB compositions it does not have the same degree of enrichment as the Site 801 alkalic basalts.
In summary, it is suggested that the Site 801 basement stratigraphy is composed of typical Pacific N-MORB followed after a short time interval (about $10 \mathrm{Ma}$ ) by separate off-axis alkaline volcanism with characteristic OIB features. Assuming a Jurassic spreading rate of 4 $\mathrm{cm} / \mathrm{yr}$ (a conservative estimate for, say, the EPR), in 10 Ma the ocean crust would have migrated $400 \mathrm{~km}$ away from the active axis before the alkalic basalts were developed. This distance is generally beyond that of most flank seamounts and supports an off-axis environment for the alkalic basalts.

\section{ACKNOWLEDGMENTS}

We would like to thank co-chiefs Roger Larson and Yves Lancelot for a scientifically stimulating and successful leg together with our shipboard colleagues for keeping us aware of interesting features other than the basement. Thanks are also due to ODP gruppenfuhrer Andy Fisher for keeping us in line and the technical staff and drilling and ship crews for continuous professional support throughout. Mar- 
garet Aikin and David Emley (Keele, United Kingdom) are thanked for providing the wealth of XRF data, Nick Walsh (Bedford New College, United Kingdom) some of the REE data, and Gordon Gilmore (Risley Research Reactor, United Kingdom) additional incompatible element data. Referees Drs. J. Natland and A. Saunders are thanked for their comments.

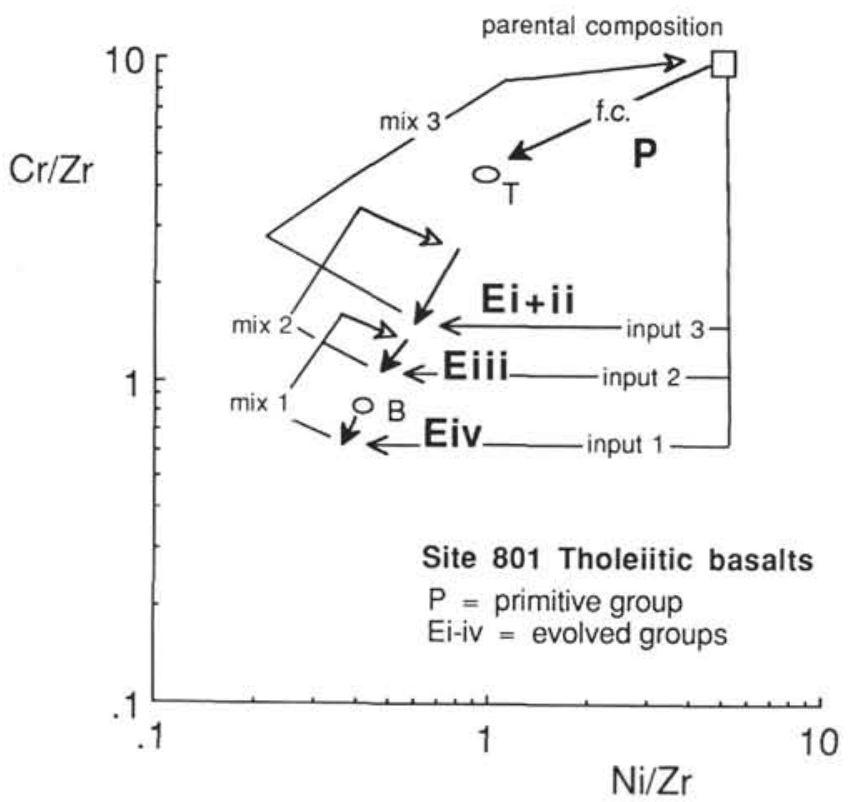

Figure 13. Diagrammatic illustration of the fractionation-mixing model for the open system generation of the tholeiitic basalt sequence, Hole 801 , using $\mathrm{Cr} / \mathrm{Zr}$ and $\mathrm{Ni} / \mathrm{Zr}$ ratios. $\mathrm{T}=$ composition at top of Site 801 sequence, $\mathrm{B}=$ composition at base of Site 801 sequence, f.c. $=$ fractional crystallization trends in different basalt groups.

\section{REFERENCES}

Adamson, A. C., 1985. Basement lithostratigraphy, Deep Sea Drilling Project Hole 504B. In Anderson, R. N., Honnorez, J., Becker, K., et al., Init. Repts. DSDP. 83: Washington (U.S. Govt. Printing Office), 121-127.

Allan, J. F., Batiza, R., Perfit, M. R., Fornari, D., and Sack, R. O., 1989. Petrology of lavas from the Lamont Seamount chain and adjacent East Pacific Rise, $10^{\circ}$ N. J. Petrol., 30:1245-1298.

Alt, J. C., and Emmermann, R., 1985. Geochemistry of hydrothermally altered basalts: Deep Sea Drilling Project Hole 504B, Leg 83. In Anderson, R. N., Honnorez, J., Becker, K., et al., Init. Repts. DSDP, 83: Washington (U.S. Govt. Printing Office), 249-262.

Alt, J. C., Honnorez, J., Laverne, C., and Emmermann, R., 1986. The structure and evolution of a submarine hydrothermal system: DSDP Site 504B. J. Geophys. Res., 91:10309-10335.

Alt, J. C., Laverne, C., and Muehlenbachs, K., 1985. Alteration of the upper oceanic crust: mineralogy and processes in Deep Sea Drilling Project Hole 504B, Leg 83. In Anderson, R. N., Honnorez, J., Becker, K., et al., Init. Repts. DSDP, 83: Washington (U.S. Govt. Printing Office), 217-247.

Ayuso, R. A., Bence, A. E., and Taylor, S. R., 1976. Upper Jurassic tholeiitic basalts from DSDP Leg 11. J. Geophys. Res., 81:4305-4325.

Baker, P. E., 1973. Islands of the South Atlantic. In Nairn, A.E.M., and Stehli, F. G. (Eds.), The Ocean Basins and Margins (Vol. 1): The South Atlantic: New York (Plenum), 493-553.

Basaltic Volcanism Study Project, 1981. Basaltic Volcanism on the Terrestrial Planets: New York (Pergamon Press).

Batiza, R., 1977. Age, volume, compositional and spatial relations of small isolated oceanic central volcanoes. Mar. Geol., 24:169-183.

, 1980 . Origin and petrology of young oceanic central volcanoes: are most tholeiitic rather than alkalic? Geology, 8:477-482.

Batiza, R., and Johnson, J. R., 1980. Trace element and isotopic evidence for magma mixing in transitional and alkalic basalts from the East Pacific Rise at $8^{\circ} \mathrm{N}$. In Rosendahl, B. R., Hekinian, R., et al., Init. Repts. DSDP, 54 Washington (U.S. Govt. Printing Office), 63-69.

Batiza, R., Rosendahl, B. R., and Fisher, R. L., 1977. Evolution of oceanic crust, 3: Petrology and chemistry of basalts from the East Pacific Rise and the Siqueiros transform fault. J. Geophys. Res., 82:265-276.

Batiza, R., and Vanko, D., 1984. Petrology of young Pacific seamounts. J. Geophys. Res., 89:11235-11260.

1985. Petrologic evolution of large failed rifts in the eastern Pacific: petrology of volcanic and plutonic rocks from the Mathematician Ridge area and the Guadalupe trough. J. Petrol., 26:564-602.

Blanchard, D. P., Rhodes, J. M., Dugan, M. A., Rodgers, K. V., Donaldson, C. H., Brannon, J. C., Jacobs, J. W., and Gibson, E. K., 1976. The chemistry and petrology of basalts from Leg 37 of the Deep Sea Drilling Project. J. Geophys. Res., 81:4231-4246.

Bonatti, E., 1975. Metallogenesis at oceanic spreading centers. Annu. Rev. Earth Planet. Sci., 3:401-431.

Bonatti, E., Honnorez-Guerstein, M. B., Honnorez, J., and Stern, C., 1976. Hydrothermal pyrite concretions from the Romanche trench (equatoria Atlantic): metallogenesis in oceanic fracture zones. Earth Planet. Sci. Lett., 32:1-10.

Brooks, C., 1976. The $\mathrm{Fe}_{2} \mathrm{O}_{3} / \mathrm{FeO}$ ratio of basalt analyses: an appeal for a standardized procedure. Bull. Geol. Soc. Den., 25:117-120.

Bryan, W. B., 1972. Morphology of quench crystals in submarine basalts. J. Geophys. Res., 77:5812-5819.

Bryan, W. B., Frey, F. A., and Thompson, G., 1977. Oldest Atlantic seafloor: Mesozoic basalts from western North Atlantic margin and eastern North America. Contrib. Mineral. Petrol., 64:223-242.

Cann, J. R., 1979. Metamorphism in the ocean crust. In Talwani, M., Harrison, C. G., and Hayes, D. E. (Eds.), Deep Drilling Results in the Atlantic Ocean: Ocean Crust. Am. Geophys. Union, Maurice Ewing Ser., 2:230-238.

de Paepe, P.. Klerkx, J., Hertogen, J., and Plinke, P., 1974. Oceanic tholeiites on the Cape Verde Islands: petrochemical and geochemical evidence. Earth Planet. Sci. Lett., 22:347-354.

Floyd, P. A., 1977. Rare earth element mobility and geochemical characterization of spilitic rocks. Nature, 269:134-137.

Floyd, P. A., Castillo, P. R., and Pringle, M., 1991. Tholeiitic and alkalic basalts of the oldest Pacific Ocean crust. Terra Nova, 3:257-265.

Floyd, P. A., and Tarney, J., 1979. First-order alteration chemistry of Leg 49 basement rocks. In Luyendyk, B. P., Cann, J. R., et al., Init. Repts. DSDP, 49: Washington (U.S. Govt. Printing Office), 693-708.

Flower, M.F.J., Ohnmacht, W., Robinson, P. T., Marriner, G., and Schmincke, H. U., 1980. Lithologic and chemical stratigraphy at Deep Sea Drilling Project sites 417 and 418. In Donnelly, T., Francheteau, J., Bryan, W. Robinson, P., Flower, M., Salisbury, M., et al., Init. Repts. DSDP, 51, 52, 53 (Pt. 2): Washington (U.S. Govt. Printing Office), 939-956.

Flower, M.F.J., Robinson, P. T., Schmincke, H. U., and Ohmacht, W., 1977 Magma fractionation systems beneath the Mid-Atlantic Ridge at $36-37^{\circ} \mathrm{N}$ Contrib. Mineral. Petrol., 64:167-195.

Fornari, D. J., Perfit, M. R., Allan, J. F., and Batiza, R., 1988. Small-scale heterogeneities in depleted mantle sources: near-ridge seamount lava geochemistry and implications for mid-ocean ridge magmatic processes. Nature, 331:511-513.

Goldfarb, M. S., 1986. Petrography of basalts from Deep Sea Drilling Project Leg 92. In Leinen, M., Rea, D. K., et al., Init. Repts. DSDP, 92: Washington (U.S. Govt. Printing Office), 459-469.

Hart, R. A., 1976. Progressive alteration of the oceanic crust. In Yeats, S. R., Hart, S. R., et al., Init. Repts. DSDP, 34: Washington (U.S. Govt. Printing Office), 433-438.

Hart, S. R., Erlank, A. J., and Kable, E.J.D., 1974. Sea floor basalt alteration: some chemical and Sr isotopic effects. Contrib. Mineral. Petrol., 44:219-230.

Hekinian, R., Thompson, G., and Bideau, D. 1989. Axial and off-axis heterogeneity of basaltic rocks from the East Pacific Rise at $12^{\circ} 35^{\prime} \mathrm{N}-12^{\circ} 51^{\prime} \mathrm{N}$ and $11^{\circ} 26^{\prime} \mathrm{N}-11^{\circ} 30^{\prime}$ N. J. Geophys. Res., 94:17437-17463.

Honnorez, J., 1981. The aging of the oceanic crust at low temperature. In Emiliani, C. (Ed.), The Sea (Vol. 7): The Oceanic Lithosphere: New York (Wiley), 525-587.

Hughes, D. J., and Brown, G. C., 1972. Basalts from madeira: a petrochemical contribution to the genesis of oceanic alkali rock series. Contrib. Mineral. Petrol., 37:91-109.

Humphris, S. E., and Thompson, G., 1978. Hydrothermal alteration of oceanic basalts by seawater. Geochim. Cosmochim. Acta, 42:107-126.

Joron, J. L., and Treuil, M., 1989. Hygromagmaphile element distributions in oceanic basalts as fingerprints of partial melting and mantle heterogeneities: a specific approach and proposal of an identification and modelling 
method. In Saunders, A. D., and Norry, M. J. (Eds.), Magmatism in the Ocean Basins. Geol. Soc. Spec. Publ. London, 42:277-299.

Lancelot, Y., Larson, R., et al., 1990. Proc. ODP, Init. Repts., 129: College Station, TX (Ocean Drilling Program).

Larson, R. L., and Chase, C. G., 1972. Late Mesozoic evolution of the western Pacific Ocean. Bull. Geol. Soc. Am., 83:3627-3644.

Leake, B. E., Hendry, G. L., Kemp, A., Plant, A. G., Harvey, P. K., Wilson, J. R., Coats, J. S., Aucott, J. W., Lunel, T., and Howarth, R. J., 1969. The chemical analysis of rock powders by automatic X-ray fluorescence. Chem. Geol., 5:70-86.

Logothetis, J., 1983. Petrography, mineralogy and, geochemistry of basalts from Hole 534A, Leg 76. In Sheridan, R. E., Gradstein, F. M., et al., Init. Repts. DSDP, 76: Washington (U.S. Govt. Printing Office), 713-717.

Ludden, J. N., and Thompson, G., 1979. An evaluation of the behaviour of the rare earth elements during the weathering of sea floor basalt. Earth Planet. Sci. Lett., 43:85-92.

Marsh, N. G., Tarney, J., and Hendry, G. L., 1983. Trace element geochemistry of basalts from Hole 504B, Panama Basin, Deep Sea Drilling Project Legs 69 and 70. In Cann, J. R., Langseth, M. G., Honnorez, J., Von Herzen, R. P. White, S. M., et al., Init. Repts. DSDP. 69: Washington (U.S. Govt. Printing Office), 747-763.

Matsuoka, A., 1990. The oldest (Middle Jurassic) radiolarians from the western Pacific. Proc. 3rd Internat. Symp. "Shallow Tethys," Japan, 1-9.

Mattey, D. P., 1982. The minor and trace element geochemistry of volcanic rocks from Truk, Ponape and Kusaie, Eastern Caroline Islands: the evolution of a young hot spot trace across old Pacific ocean crust. Contrib. Mineral. Petrol., 80:1-13.

Natland, J., 1977. Composition of basaltic rocks recovered at Sites 367 and 368 Deep Sea Drilling Project, near the Cape Verde Islands. In Lancelot, Y., Seibold, E., et al., Init. Repts., DSDP, 41: Washington (U.S. Govt. Printing Office), 1107-1112.

, 1980. Crystal morphologies in basalts dredged and drilled from the East Pacific Rise near $9^{\circ} \mathrm{N}$ and the Siqueiros fracture zone. In Rosendahl, B. R., Hekinian, R., et al., Init. Repts. DSDP, 54: Washington (U.S. Govt. Printing Office), 605-633.

Natland, J., Adamson, A. C., Laverne, C., Melson, W. G., and O'Hearn, T., 1983. A compositionally nearly steady-state magma chamber at the Costa Rica Rift: evidence from basalt glass and modal data, Deep Sea Drilling Project Sites 501, 504 and 505. In Cann, J. R., Langseth, M. G., Honnorez, J., Von Herzen, R. P., White, S. M., et al., Init. Repts. DSDP, 69: Washington (U.S. Govt. Printing Office), 811-858.

Norrish, K., and Hutton, J. T., 1969. An accurate X-ray spectrographic method for the analysis of a wide range of geological samples. Geochim. Cosmochim. Acta, 33:431-453.

O'Hara, M. J., and Mathews, R. E., 1981. Geochemical evolution in an advancing, periodically replenished, periodically tapped, continuously fractionated magma chamber. J. Geol. Soc. London, 138:237-278.

Pearce, J. A., and Norry, M. J., 1979. Petrogenic implications of Ti, Zr, Y and $\mathrm{Nb}$ variations in volcanic rocks. Contrib. Mineral. Petrol., 69:33-47.

Pearce, J. A., Rogers, N., Tindle, A. J., and Watson, J. S., 1986. Geochemistry and petrogenesis of basalts from Deep Sea Drilling Project Leg 92, Eastern Pacific. In Leinen, M., Rea, D. K., et al., Init. Repts. DSDP, 92: Washington (U.S. Govt. Printing Office), 435-457.

Rhodes, J. M., Blanchard, D. P., Rodgers, K. V., Jacobs, J. W., and Brannon, J. C., 1976. Petrology and chemistry of basalts from the Nazca Plate. Part
2: Major and trace element chemistry. In Hart, S. R., Yeats, R. S., et al., Init. Repts. DSDP, 34: Washington (U.S. Govt. Printing Office), 239-244.

Rhodes, J. M., Dungan, M. A., Blanchard, D. P., and Long, P. E., 1979. Magma mixing at mid-ocean ridges: evidence from basalts drilled near $22^{\circ} \mathrm{N}$ on the Mid-Atlantic Ridge. Tectonophysics, 55:35-61.

Saunders, A. D., 1983. Geochemistry of basalts recovered from the Gulf of California during Leg 65 of the Deep Sea Drilling Project. In Lewis, B.T.R., Robinson, P., et al., Init. Repts. DSDP, 65: Washington (U.S. Govt. Printing Office), 591-621.

Staudigel, H., Hart, S. R., and Richardson, S. H., 1981. Alteration of the oceanic crust: processes and timing. Earth Planet. Sci. Lett., 52:311-327.

Stillman, C. J., Furnes, H., LeBas, M. J., Robertson, A.HF., and Zielonka, J., 1982. The geological history of Maio, Cape Verde Islands. J. Geol. Soc. London, 139:347-361.

Sun, S. S., and McDonough, W. F., 1989. Chemical and isotopic systematics of ocean basalts: implications for mantle composition and processes. In Saunders, A. D., and Norry, M. J. (Eds.), Magmatism in the Ocean Basins. Geol. Soc. Spec. Publ. London, 42:313-345.

Tarney, J., Saunders, A. D., Weaver, S. D., Donnellan, N.C.B., and Hendry, G. L., 1979. Minor element geochemistry of basalts from Leg 49, North Atlantic Ocean. In Luyendyk, B. P., Cann, J. R., et al., Init. Repts. DSDP, 49: Washington (U.S. Govt. Printing Office), 657-691.

Thompson, G., 1983. Basalt-seawater interaction. In Rona, P. A., Bostrom, K., Laubier, L., and Smith, K. L. (Eds.), Hydrothermal Processes at Seafloor Spreading Centers: New York (Plenum), 225-278.

Thompson, G., Bryan, W. B., Frey, F. A., Dickey, J. S., and Suen, C. J., 1976. Petrology and geochemistry of basalts from DSDP Leg 34, Nazca Plate. In Yeats, R. S., Hart, S. R., et al., Init. Repts, DSDP, 34: Washington (U.S. Govt. Printing Office), 215-226.

Thompson, G., Bryan, W. B. and Humphris, S. E., 1989. Axial volcanism on the East Pacific Rise, $10-12^{\circ}$ N. In Saunders, A. D., and Norry, M. J. (Eds.), Magmatism in the Ocean Basins. Geol. Soc. London Spec. Publ., 42:181-200.

Thompson, R. N., 1982. Magmatism of the British Tertiary volcanic province. Scott. J. Geol., 18:49-107.

Tual, E., Jahn, B. M., Bougault, H., and Joron, J. L., 1985. Geochemistry of basalts from Hole 504B, Leg 83, Costa Rica Rift. In Anderson, R. N., Honnorez, J., Becker, K., et al., Init. Repts. DSDP, 83: Washington (U.S, Govt. Printing Office), 201-214.

Wood, D. A., Gibson, I. L., and Thompson, R. N., 1976. Element mobility during zeolite facies metamorphism of the Tertiary basalts of eastern Iceland. Contrib. Mineral. Petrol., 55:241-254.

Wood, D. A., Tarney, J., Varet, J., Saunders, A. D., Bougault, H., Joron, J. L., Treuil, M., and Cann, J. R., 1979. Geochemistry of basalts drilled in the North Atlantic by IPOD Leg 49: implications for mantle heterogeneity. Earth Planet. Sci. Lett., 42:77-97.

Zindler, A., Staudigel, H., and Batiza, R., 1984. Isotope and trace element geochemistry of young Pacific seamounts: implications for the scale of upper mantle heterogeneity. Earth Planet. Sci. Lett., 70:175-195.

Date of initial receipt: 25 April 1991

Date of acceptance: 6 January 1992

Ms 129B-129 

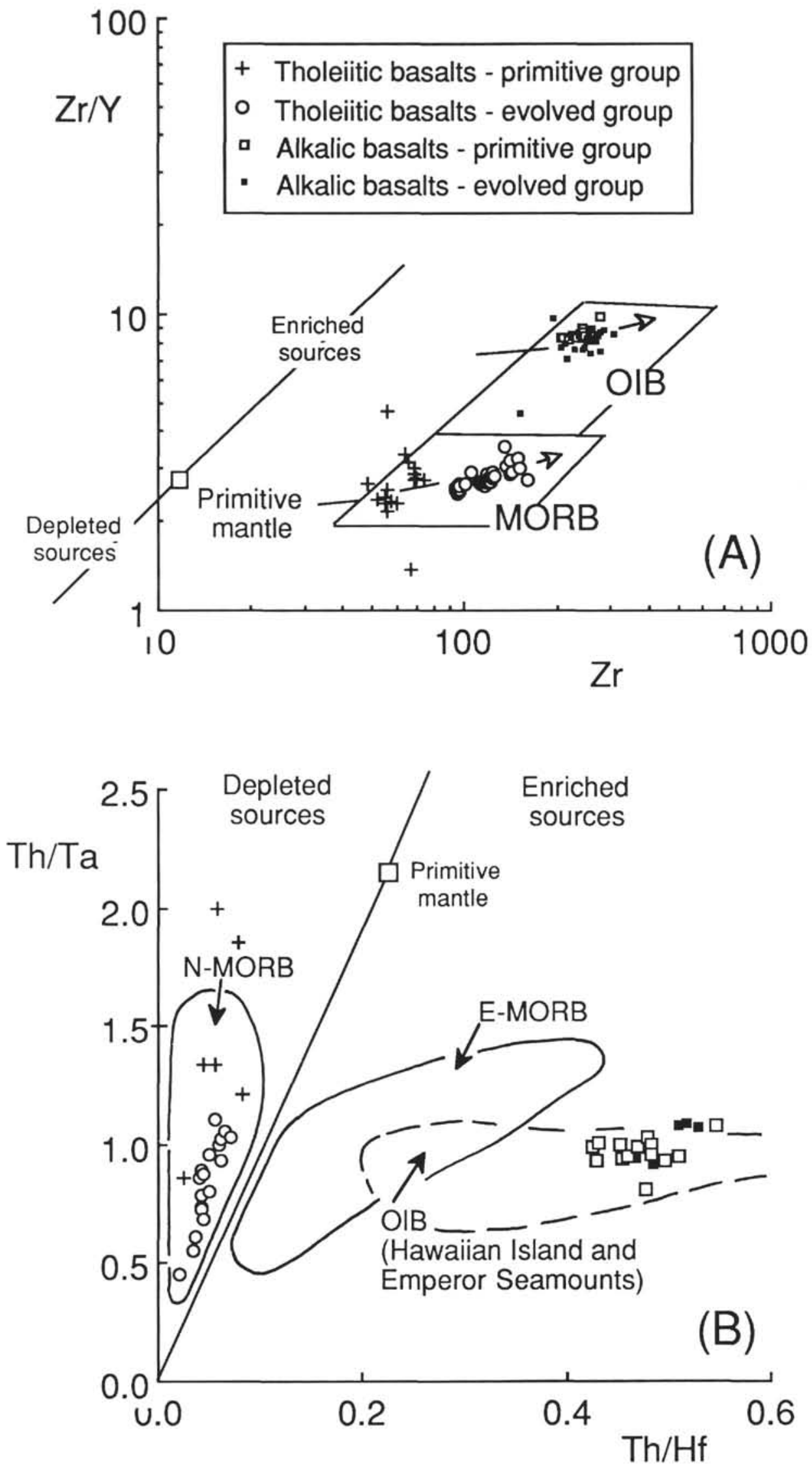

Figure 14. Distribution of Site 801 basalts relative to depleted and enriched mantle sources (Sun and McDonough, 1989 ) and typical N-MORB and OIB compositions. $\mathrm{Zr} / \mathrm{Y}$ - $\mathrm{Zr}$ diagram (A) and fields from Pearce and Norry (1979); $\mathrm{Th} / \mathrm{Ta}-\mathrm{Th} / \mathrm{Hf}$ diagram (B) from Joron and Treuil (1989), with fields constructed from data by Tual et al. (1985). 


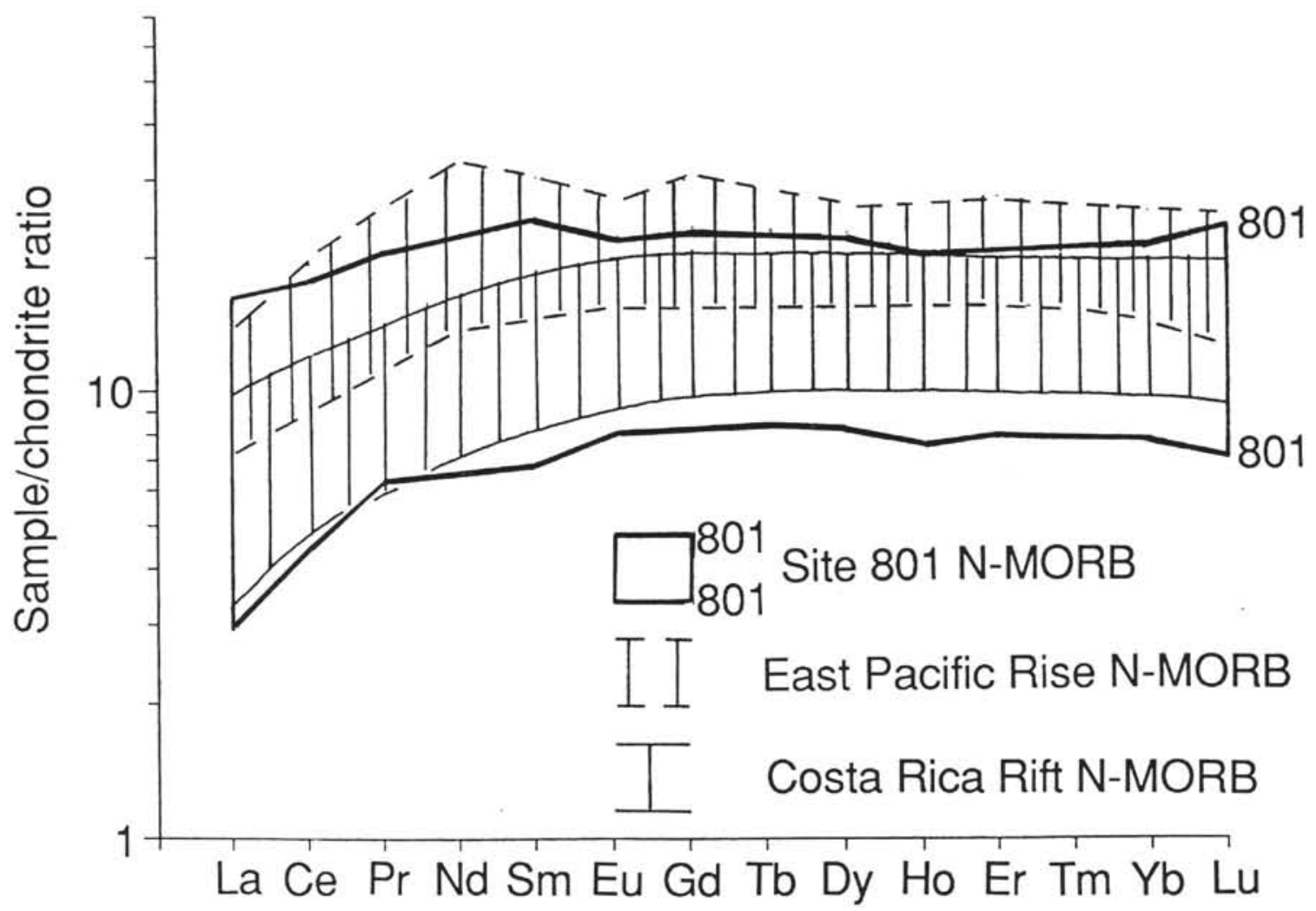

Figure 15. Envelope of chondrite-normalized REE patterns for Site 801 tholeiites compared with the range of variation at the EPR $\left(10^{\circ}-12^{\circ} \mathrm{N}\right)$ (Thompson et al., 1989) and Costa Rica Rift (Tual et al., 1985).

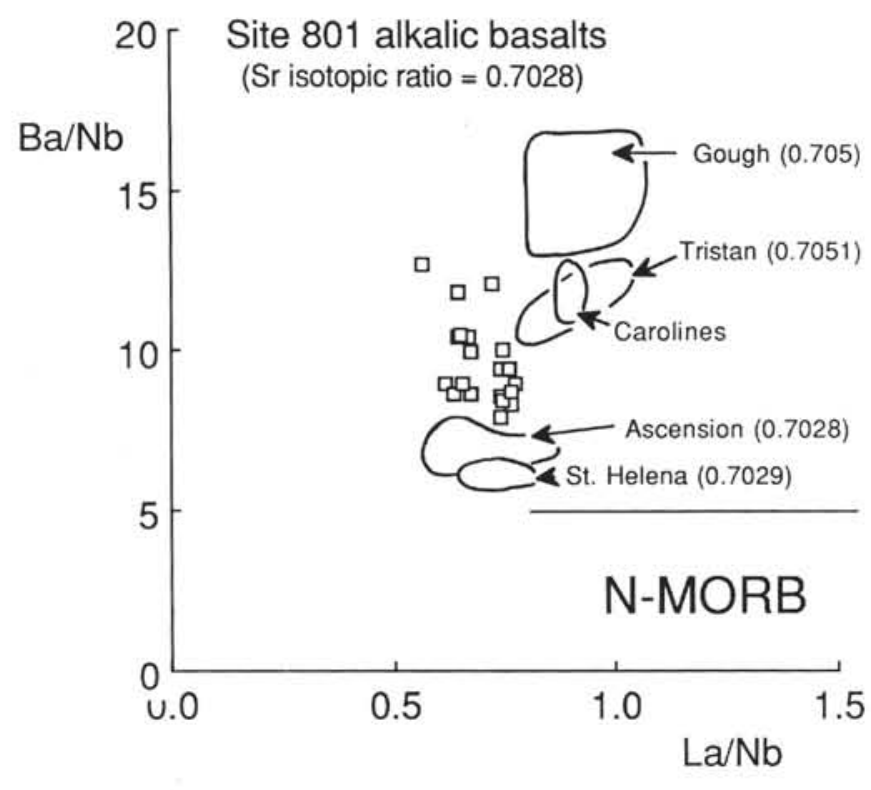

Figure 16. Comparison of ratios of highly incompatible elements in the freshest Site 801 alkalic basalts with enriched mantle-type OIB (with high ${ }^{87} \mathrm{Sr} /{ }^{86} \mathrm{Sr}$ ratios) and HIMU-type OIB (with lower Sr isotopic ratios). Data from Sun and McDonough (1989) and Mattey (1982; Caroline Islands).

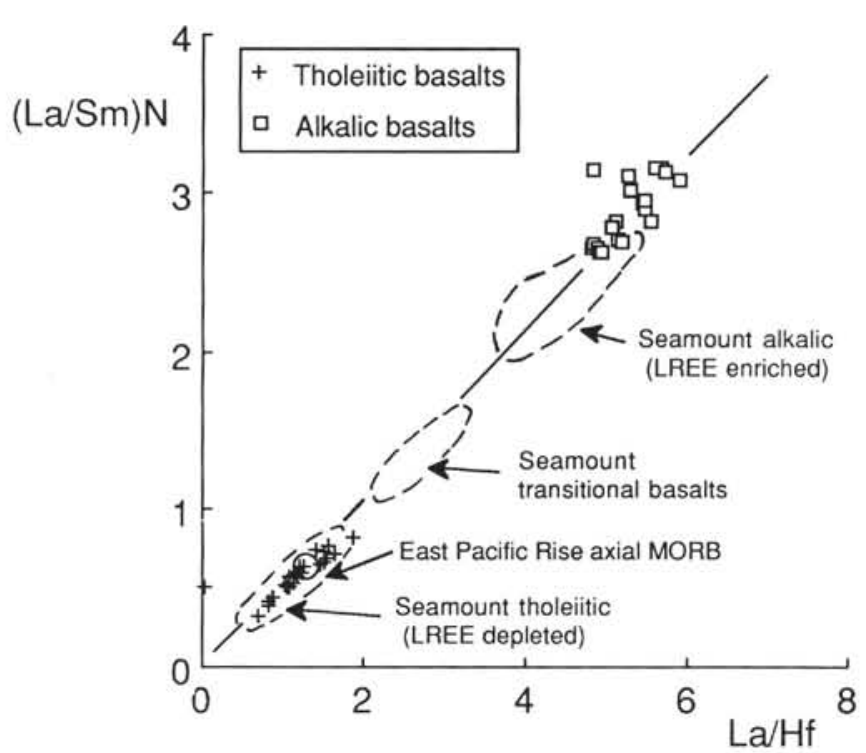

Figure 17. Comparison of Site 801 tholeiitic and alkalic basalts with the spread of $(\mathrm{La} / \mathrm{Sm})_{\mathrm{N}}$ and $\mathrm{La} / \mathrm{Hf}$ ratios in near-axis East Pacific Rise seamounts (data from Batiza and Vanko, 1984; Fornari et al., 1988). Note that the Site 801 basalts fall on the binary mixing line for compositionally diverse seamounts, although no intermediate compositions are present. 


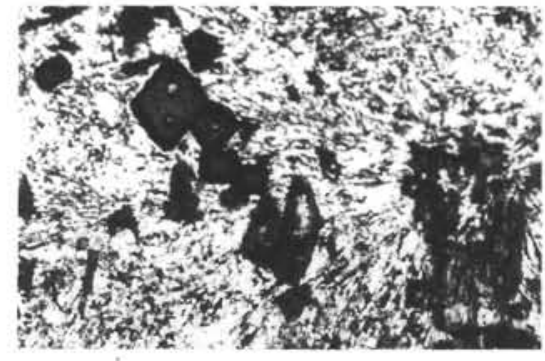

1

$0.1 \overline{\mathrm{mm}}$

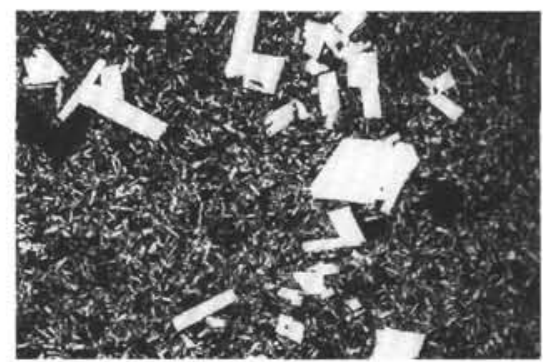

4

$0.5 \overline{\mathrm{mm}}$

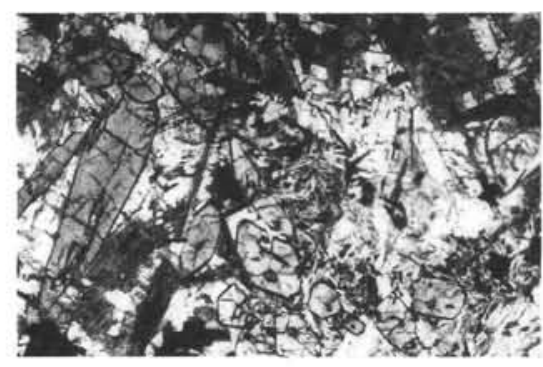

7

$0.5 \mathrm{~mm}$

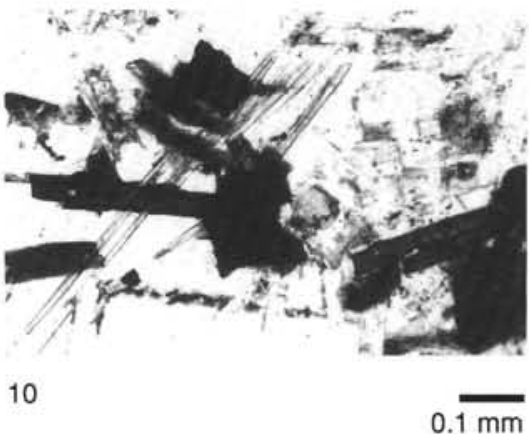

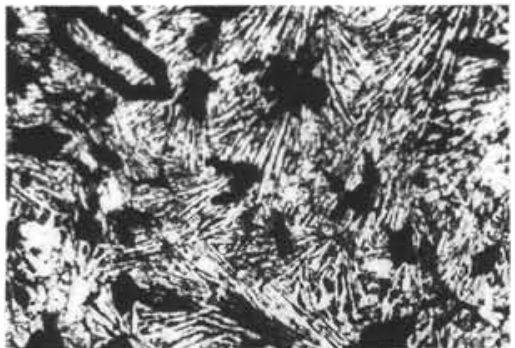

2

$0.1 \mathrm{~mm}$

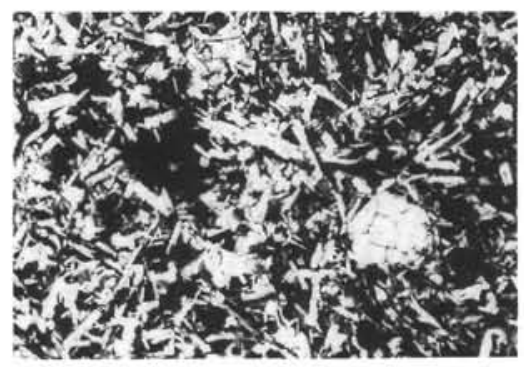

5

$0.5 \overline{\mathrm{mm}}$

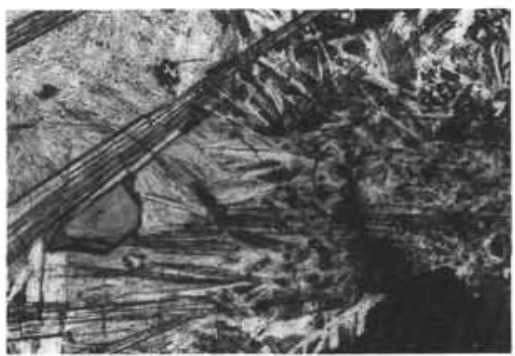

8

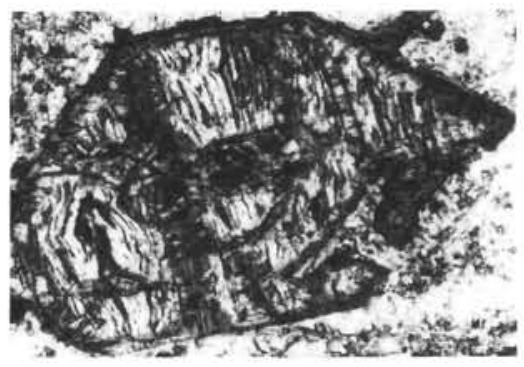

11

$0.1 \mathrm{~mm}$

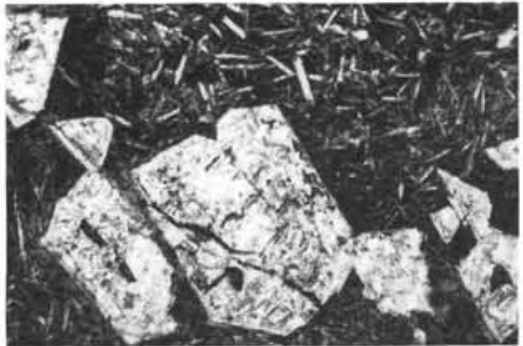

3

$0.5 \mathrm{~mm}$

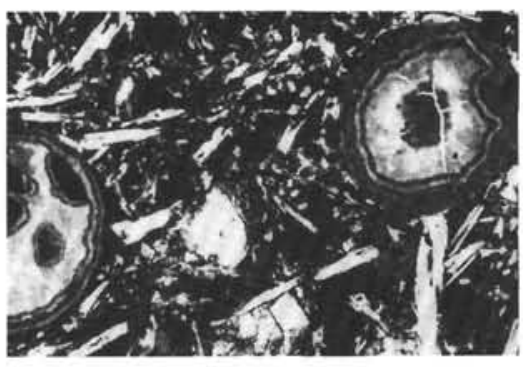

6

$0.1 \mathrm{~mm}$

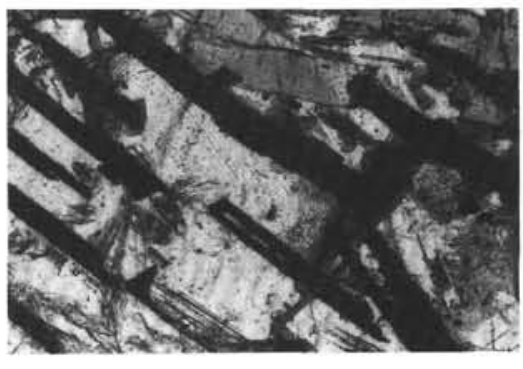

$0.1 \mathrm{~mm}$

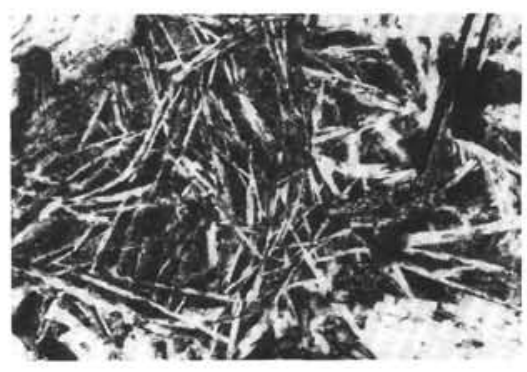

12

$0.1 \mathrm{~mm}$

Plate 1. Photomicrographs illustrating petrographic and textural features of Site 801 tholeiitic basalt $(1-6)$ and alkalic basalt $(7-12)$ submarine flows $(\mathrm{ppl}=$ plane polarized light; $x p=$ crossed polars). 1. Dark margined spinel and smectite-replaced olivine microphenocrysts in quenched variolitic martix, Sample 129-801C-6R-2, 119-124 cm (ppl). 2. Smectite-pseudomorphed olivine microphenocrysts (one hopper-faced crystal) in plagioclase-rich variolitic matrix, Sample 129-801C-6R-2, $119-124 \mathrm{~cm}$ (ppl). 3. Plagioclase megaphenocrysts in plagioclase microlite matrix, near the top of unit C9, Sample 129-801-5R-1, 12-13 cm (ppl). 4. Plagioclase phenocrysts and dark olivine pseudomorphs in granular matrix, Sample 129-801C-11R-2, 81-86 cm (ppl). 5. Flow interior with serrated plagioclase, granular clinopyroxene, dark palagonite mesostatis, and a single clinopyroxene microphenocryst, Sample 129-801C-7R-3,0-5 cm (ppl). 6. Vesicles infilled with zoned smectite and dark corroded pyrite, Sample 129-801C-7R-3, 0-5 cm (ppl). 7. Flow interior with prismatic and basal sections of elongate titanaugite crystals, plagioclase laths, and quenched plagioclase microlites in smectite-replaced mesostasis, Sample 129-801C-1R-1, 119-120 cm (ppl). 8. Flow interior mesostasis with white plagioclase microlites, radiating smectite clumps (replacing original glass), dark titanomagnetite and acicular apatite crystals, Sample $129-801 \mathrm{C}-1 \mathrm{R}-1,119-120 \mathrm{~cm}$ (ppl). 9. Corroded acicular titanomagnetite crystals showing local preferred orientation in the flow interior, Sample 129-801C-1R-1, 119-120 cm (ppl). 10. Dark plates of biotite growing from titanomagnetite grains and traversed by acicular apatite crystals, Sample 129-801B-42R-1, 86-87 cm (ppl). $\quad 11$. Euhedral olivine replaced by talc (white wavy plates) and green smectite (dark fibrous material), Sample 129-801 B-43R-1, 20-21 cm (ppl). 12. Mesostasis composed of quenched plagioclase microlites, minor biotite, and glass (now completely replaced by fibrous smectite), Sample 129-801B-41R-1, 25-26 cm (ppl). 